\title{
Vepsa-põhjavene karjusekultuur - rollid, tabud ja seksuaalsus parasvöötme metsavööndi traditsioonilises ühiskonnas
}

\author{
Madis Arukask
}

Teesid: Käesolevas artiklis käsitletakse karjuse rolli ja sellega seotud maagiat läänemeresoome (valdavalt vepsa) ja põhjavene folkloorimaterjalidele ja sellealastele varasematele uurimustele toetudes. Traditsioonilises kultuuritüübis, mille mõju antud juhul on kestnud paiguti 20. sajandi lõpuni, on karjus olnud metsavööndi rahvastel inimese ja looduse vahendaja. Kuivõrd koduloomad on olnud oluline osa kogukonna ressursist, on nende hoidmisel tulnud arvestada läbisaamist animistliku maailma erinevate jõududega. Karjus kui selle kompleksi võtmeisik on olnud osaline vastavas maagilises lepingus ning talle on kehtinud karjatamisperioodil mitmesugused kokkuleppelised tabud. Tema osa on olnud mitte üksnes karja hoidmine, vaid omal moel ka inimühiskonna moraalsuse kontroll ning looduse ja inimühiskonna vaheliste pingete kanaliseerimine. See on kujundanud karjuse iseloomuliku sotsiaalse rolli talle ainuomase käitumisega, milles paistavad silma ühiskondliku tõrjutuse ja tavalisest erineva soolise käitumisega seotud jooned. Huvipakkuv on selle rolli genees, mis viitab sugulusele teadja-institutsiooniga, kuid milles leidub mõjutusi ka kõrgreligioonist.

Märksõnad: karjus, kultuuriline sugu, maagia, põhjavene, tabu, teadja, vepsa 


\section{Sissejuhatus}

Inimlikus plaanis moodustab tõelisuse see, mida on õpitud kultuuriliselt kogema ja seletama. Sellised kogemis- ja seletamissüsteemid võivad olla üpriski erinevad, varieerudes, sarnanedes või vastandudes põhikontseptsioonides aegruumiliselt. Üldjuhul ei ole kellelegi harjumuspärane tõelisus samamoodi (kui üldse) mõistetav sellest väljaspool olijale. Uskumise asemel tuleb mängu mitteuskumine, mis kuulutab uudse või senitundmatu kas väljamõelduks, mittetõeliseks või valeks. Kultuuriuurija asi pole selliste argiste või institutsionaalsete hinnangutega kaasaminemine, vaid ühe või teise uskumussüsteemi sisemise toimimise mõistmine, võimalusel selle tõlkimine endale arusaadavamasse keelde. Sageli on mitteinstitutsionaalseid, folkloorseid tõelisusi mõista keerukam kui tõelisusi, milles on juba enesekirjelduslikult juurutatud mingi (kasvõi osaliselt) formaliseeritud seletussüsteem.

Rahvapärased uskumussüsteemid pole enamjaolt rangelt fikseeritud, nad on vaid formaalselt käideldavad. Siiski on lähemal uurimisel hoomatavad ja äratuntavad teatud kontseptuaalsed tihedused, mis üht või teist süsteemi enim iseloomustavad ning mille kirjeldamiseks on olemas iseloomulik sõnavara ja narratiive süžeestik. Et neil juhtudel ei ole tegemist vaid fiktiivse tekstikorpusega, kinnitab rahvajuttudes sageli esile tulev kogemuslik pool. Folkloorsed žanrid ja praktikad moodustavadki tegelikkust taastootva mehhanismi, mis on juhtinud inimeste käitumist, kuid milles on olnud ruumi ka loovusele, taasseletamaks ja mõistmaks sellesama tegelikkuse erinevaid aspekte igapäevaelus. See on üldjuhul hajusavõitu tervik, mille alalhoidmiseks on vaja seda ennekõike aktsepteerida ja jagada ning samaaegselt ka igapäevaelus läbi viia. Kui mingisugune uskumuslik tervikpilt liigselt hajub, on tal oht muutuda kas pelgalt fiktiivseks või vähemalt seletuslikult ebapiisavaks - ta ei ole enam tegelik.

Sarnaselt kaasaegsest erinevale tegelikkuse modelleeritusele on erinevad olnud ka ühiskondlikud rollijaotused. Uurides üht või teist folkloorset praktikat või vaadeldes kasvõi nende kohta käivaid, neid saatnud või kommenteerinud rahvaluuleliike, märkame tingimata ka erinevusi meile harjumuspärasest inimkäitumisest, iseäranis näiteks iseloomulike usundispetsialistide omas, kelle teadmised ja rolliomased käitumisviisid on erinenud ühiskonna realiikmete omast ning kellesse suhtumine on sellest tulenevalt olnud ka teistsugune. Kultuurilistes kirjeldustes jääb paljugi sellist väljaspool olijale (aga 
sageli ka ühiskonnasisesele realiikmele) arusaamatuks, seletamatuks või mõistetamatuks, kuid paljudel juhtudel ka lihtsalt märkamatuks. Paratamatult on nii, et millegi teadasaamiseks ja nägemiseks on meil väljaspool olijatena vaja vähemalt vihjet millegi meile tundmatu olemasolust antud kultuuris.

Usundiliselt eriskummaliste ja tihti peidetud fenomenidele jälile saamiseks vajab uurija niisiis eelteadmist, aga ka vaistu kultuuritekstist sellekohaste märkide väljalugemiseks. Alahinnata ei saa siin juhuse või õnne osa, kuivõrd üldjuhul ei ole rahvapärases käitumises mitmed sisemiselt olulised asjad mõeldud eksponeeritavate või vastutulelikult lahtiseletatavatena. Pahatihti me õieti ei teagi, mis ja kui palju ühe või teise uuritava kultuuri või kogukonna puhul meie eest igaveseks varjule jääb ja kui tihti me tegelikult suudame puudutada vaid atraktiivsemat pealispinda.

\section{$* * *$}

Käesoleva uurimuse teemaks on karjuse roll ning tema tegevusega seotud uskumused ja praktikad vepsa (paralleelaineses võrdlevalt kogu põhjavene) kultuuriareaalis 20. sajandil ning siinkirjutaja poolt sel aastatuhandel kogutud materjalis. Karjuse roll on nimetatud aegruumis olnud selgelt eriline, mis loob eelduse sellekohase kirjelduse usutavuseks ja teostatavuseks. Käsitlusi selles teemavallas on ilmunud juba varemgi, iseäranis vene uurijate poolt, millest suurele osale selles artiklis ka viidatakse. Kindlasti ei saa aga karjusega seotud uskumusi eri kohtades ja eri kogemusprismade läbi taandada ühele unifitseeritud seletusele, ehkki millegi sellise suunas võib teatud tõenäosusega liikuda. Jäävad areaalsed erinevused, ennekõike aga tõsiasi, et sellekohane eri aegadel ja eri tingimustes kogutud materjal ei saa kunagi olla piisavalt tihe, nagu ilmsesti pole samased ka erinevate uurijate lähenemisnurgad ja taotlused. Vepsa karjusemaagiat puudutav korpus pole kindlasti sedavõrd täiuslik, et see saaks luua eelduse antud teema ammendavaks käsitluseks. Tänapäevaste uurijatena oleme aga nii või teisiti eemaldunud traditsioonilisest tegelikkusest, mis moodustab antud teema elulise tausta.

Tegemist on tundliku ja osati tabulise teemaga, mis tähendab, et rahvapärane seletuslik repertuaar on juba paratamatult hägus, aimduslik või isegi tahtlikult moonutatud. Samas inspireerib teemaga tegelema selle ekstraordinaarsus ning asjaolu, et karjuse roll on ühendanud mitmeid tähtsaid parasvöötme metsa- ja alekultuuri do- 
minantseid sfääre ja tegevusalasid - eelkõige karjakasvatust kui üht kesksemat elatusvahendit sajandite jooksul, metsa ja inimühiskonda nende vastanduses ja koostöös, animistlikku partnerlust, üleloomulikkust ning paljut muudki kuni sooliste teemadeni välja.

Käesoleva uurimuse põhiallikateks on peamiselt aastatel 20082011 Ojati jõe äärsetes vepsa külastutes (ennekõike Vidlas, Nemžas, Kurbas ja Ladvas) läbi viidud välitöödelt saadud informatsioon, samuti eesti (Kristi Salve), vene (olulisematest teiste seas Dmitri Zelenin, Andrei Moroz, Gennadi Durasov) ja soome (Kaija Heikkinen, IrmaRiitta Järvinen jt) teadlaste asjakohased uurimused ja materjalikogud. Justnimelt vepsa ainese puhul on põhiallikaks Irina Vinokurova vastavad uurimused. Nimetatud uurimustes on ühisest areaalist tulenevalt paljugi kattuvat, seetõttu pole ainese esitusel ja analüüsil viidatud sageli absoluutselt kõigile allikatele. Teoreetiliselt on siinkirjutajat inspireerinud ennekõike piiride kontseptsioon läänemeresoome rahvaste rahvausus (Veikko Anttonen, Laura Stark), samuti religioossuse kognitivistlik liigitusvõimalus (Harvey Whitehouse), ning kultuurilise soo (gender) konstrueerimisega seotud küsimused (Laura Stark, Lotte Tarkka, Tatjana Štšepanskaja jt).

\section{Vepsa kultuuriline kujunemislugu loodusmaastike taustal}

Vepslaste ajalooliselt väljakujunenud asuala jääb tinglikult kolme Loode-Venemaa suure järve - Laadoga, Äänisjärve ja Valgejärve (Beloje ozero) vahelisse piirkonda, tänaseks ennekõike Äänisjärve edelarannikule (põhjavepslased), Leningradi oblasti lõuna-, ida- ja viimasega külgnevasse Vologda oblasti lääneossa (keskvepslased; vepslaste asualast ajaloolises plaanis vt ka Joalaid; Joalaid 1998: 50-56). Neis paikkondades on kokkukahanevalt elatud viimastel sajanditel, olles paiguti üpris isoleeritud ümbritsevatest venelastest. Viimane kehtib just keskvepslaste kohta. Samas tuleb aga silmas pidada, et suurem osa vepslaste nüüdsest naabrusalast - s.o Laadogasse voolavate jõgede (Volhov, Sjäs, Paša, Kapša, Ojat, Süvar) basseinid, ilmsesti lõunapoolne Karjala laiemalt, Äänisjärve lõuna- ja kagukallas ning nüüdseks juba venestunud Vologda oblasti alad Valgejärveni välja on tegelikult substraatselt vepsalikud. Kaasaegsetes vepslastes tuleb seega näha selle rahva kõige perifeersemat allesjäänud osa, suures osas naabruspiirkondade venelastes (loomulikult eranditega) võib aga näha mitte 
väga kauges minevikus venestunud vepslasi või läänemeresoomlasi laiemalt.

Viimane märkus on oluline just seetõttu, et vepslaste etnogenees viimasel aastatuhandel on olnud assimileerumise ja taandumise lugu, aga ka ümberasumiste ja liikumiste lugu. Vepsa arheoloogiline lähtekodu on kõige levinumate seisukohtade kohaselt Laadoga järve kagukallastel, millest annavad tunnistust iseloomulikud kurgaanid (alates 9. või 10. sajandist; vrd Pimenov 1965: 53 jj; Golubeva 1987: $52 \mathrm{jj}$ ) sinna voolavate jõgede kallastel. Vene leetopissides seostub sellega etnonüüm ves, olles seotud ennekõike sündmustega 9. ja 10. sajandil (Pimenov 1965: 21 jj). Vessid võtsid koos varjaagidega osa Loode-Venemaa jõgesid pidi kulgevate kaubateede haldamisest ning nendele kontrollpunktide rajamisest. Slaavi hõimude liikumisel põhja poole olid nad 9. sajandil osalised Russi riigi loomisel, esimese pealinnaga Vana Laadogas Volhovi jõel kuni Kiievi Venemaa tekkimiseni, kus vessid koos teiste läänemeresoomlastega osalesid skandinaavia päritolu vürst Olegi sõjaväes Kiievi vallutamisel 882. aastal (Pimenov 1965: 27).

Näeme, et jõgesid ja kaubateid hallanud, poliitilist ja sõjalist aktiivsust ilmutanud vessid olid ilmselgelt kontaktirahvas, kes tegutses toonase elu geopoliitilistes sõlmpunktides seda elu ühtlasi mõjutades. Nende aktiivsus küündis idas välja Valgejärveni, sealt edasi aga Volga veeteed mööda bolgarite riigini ning araabia maailma. Vesside (resp. tšuudide) piirkondi võis olla ka põhjapoolne ala teiselpool Valgejärve ja Äänist (ajalooline tšud zavolotšskaja). Vene riikluse arengutes aktiivne osalemine oli ilmsesti nende eliidi ning seejärel ka lihtrahva järk-järgulise venestumise peapõhjus Loode-Venemaal. Vesse-vepslasi peetigi, sarnaselt merjalaste ja muromlastega, assimileerunuteks. Selle seisukoha mõjukas esitaja oli vene ajalookirjutuse isa Nikolai Karamzin (1816; vt Pimenov 1965: 33). Tõepoolest, tänaseks on kunagiste suuremate kaubajõgede basseinid ammu venestunud. Erandit kujutab siin vaid Ojati jõgikond, kus asub viimaseid silmatorkavaid (kesk-)vepsa külastute võrgustikke.

Saame järeldada, et keskajast alates on vepslased kontaktialtitest vessidest kujunenud isolatsioonirahvaks, kelle isoleeritus ja sellega kaasnenud arhailine eluviis kvintesseerus nende teadusliku "taasavastamisega" 19. sajandi esimesel poolel (aastal 1824) Anders Johan Sjögreni poolt. Mööndustega võib öelda, et vepslastes võib näha kunagiste vesside perifeerset segmenti, rahvarühma, kelle keskustest eemalejäävam elujärg viis loomulikul moel eraldumise ja teatava kultuurilise konserveerumiseni. Ilmselt tuleb meid huvitava 


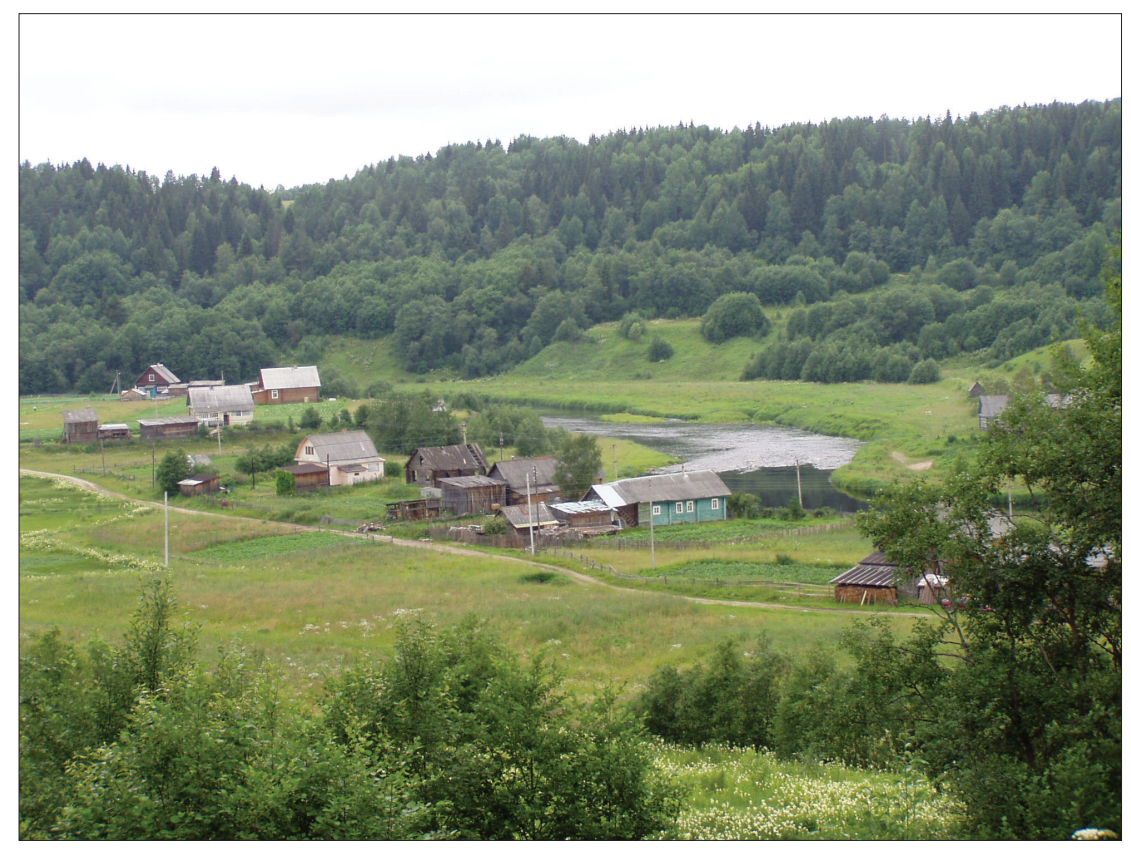

Foto 1. Vidla külastu Ojati jõe orus. Madis Arukase foto 2007.

karjusetemaatika puhul seda tausta silmas pidada. Kuigi paljud karjusekultuuri siinkäsitletavad jooned on iseloomulikud mitmel pool mujalgi, on nende säilimisel oma osa ka arhailisel (ka omakeelsel) kultuurikontekstil, ning lisaks eelmainitud asjaolul, et naabruskonnast pärit analoogiline vene materjal võib suure tõenäosusega baseeruda just vepsa substraadil.

Vepslaste asustusloos on ilmsesti suurimat osa mänginud nende liikumine jõgesid pidi ning edasine taandumine sügavamale metsastesse-soistesse järvederikastesse sisemaa piirkondadesse (Mullonen 1994: 122-124; 2005: 57-60). See ajalooline levimine on olnud ennekõike hõimkondlikult kollektiivne, mida kinnitab ka vepsa kohanimede uurimine. Vepsa asustuspunktid (külad, külaotsad) on oma nimetuse saanud tihti asustajahõimu järgi. Kohanimede vanima kihi moodustavad loodusnimed (seotud näiteks erinevate loomaliikide nimetustega), 
milles võib näha viidet nii (totemistlikule) looduskultusele kui ka hõimunimede kunagisele looduspõhilisusele.

Vaieldamatult on levinumaid osiseid vepsa kohanimedes seotud veekogude nimetustega - järv, jõgi, oja. Need nimetused viitavad otseselt ajaloolisele asumisele ennekõike veekogude läheduses, milles võib veenduda tänapäevani. Omakorda annab see kinnitust suuremate ja väiksemate veekogude rohkusest kolme suure järve vahelises piirkonnas. Kuni heade maismaateede tekkimiseni vägagi hilisel ajal on veed nii suvel kui kinnikülmunutena talvel pakkunud võimalust liikumiseks ja sidepidamiseks. Näeme siin vete tähtsust vepslaste aja- ja kultuuriloos nii kaubitsemisel kui ka eraldumisel. Samal ajal on veekogud olnud vaid suurte metsa- ja soomassiivide liigendajad ja piiritlejad. Vaieldamatult domineerivam maastikuvorm ning eluliselt vististi ka dominantsem on vepslaste jaoks hilisematel sajanditel olnud ikkagi mets.

Lisaks liikumisele ja asustuslikule levimisele vesitsi pole välistatud ka metsa osa asustuskoha valikul, esmajoones seoses aletamise ja karjatamisega. 20. sajandi teisel poolel vepslaste uurimisega tegelnud Tanel Moora (2008) arvates on just aletamiseks sobilike mäekülgedel kasvavate metsade valimine võinud olla üks vepslaste asustusloolist liikumist tinginud asjaolusid. Aletamist iseloomuliku soomeugrilise traditsiooniökoloogilise usundilise etapina on märkinud ka Lauri Honko. Tema järgi on just aletajatele erinevalt põlispõllunduse viljelejatest eriti iseloomulik animistlik tunnetus ning mitmekesine suhtlemine loodusvaimudega, mis põlluharijatel kasvab üle dualistlikuks vastandumiseks (Honko 1994: 68). Seega võime vägagi metsalembeses alekultuuris näha vepsa rahvakultuuri tegelikku juurt, mis ei ole lõppkokkuvõttes silmatorkavalt mõjutunud vahepealsest ajaloolisest vesside innovatiivsusest.

Aletajatele omase kultuuritüübi ja sellest tuleneva uskumusmaailma suur inerts on kandunud ka mujale põhjavene areaali, elades üle nii keelelise assimileerumise, samuti kristluse kui tüüpiliselt põllumajanduslikust keskkonnast tärganud dualistliku uskumussüsteemi hilisemad intensiivsed mõjud. Lauri Honko nimetab sellega seoses paigahaldjate kultuse levimist, samuti teadja-ravitseja institutsiooni teatavat väljakujunemist ja kesksust. Honko mõneti evolutsionistliku mudeli järgi hakkavad need iseloomulikud jooned põlluharijarahvastel hägustuma või saavad vaimolendid ja teadjad leviva dualistliku vaate tõttu negatiivse konnotatsiooni, hakates niiviisi kasvava inimkesksuse seisukohalt demoniseeruma ja vastanduma. Ilmsesti võime vepsa 
(resp. põhjavene) karjuseski näha teadjale iseloomulikke jooni, ehkki teadja institutsioon on vaadeldavas kultuuriareaalis olemas ka selgelt iseseisvana.

Alekultuur on olnud karjatamisega selges seoses. Metsa sees aletamisel paljaks põletatud maatükid on sobinud loomade metsakarjatamiseks, mis on olnud peamine karjatusviis enne spetsiaalsete kultuurkarjamaade teket 20. sajandil. Aletamise ja metsakarjatamise tõttu põimus inimese elu metsaga märksa naturaalsemalt kui põlluharijatel. Kumbki tegevus ei olnud oma olemuselt anastav nagu seda on uudismaa raadamine põlispõllunduses, mis on seotud suuremate metsaalade langetamise ja ülesjuurimisega - ehk siis maa lõpliku anastamisega metsa (või metsikuse) käest. Vastupidi, karjatamine, nagu ka muud metsaga seotud tegevused - küttimine (ja kalastamine), seente ja marjade korjamine või ka metsas asunud pühakohtades käimine, on põhinenud partnerlusel vaimolenditega, milline (maagiline) suhtlusmudel on endasse hiljem võinud haarata mitte ainult suhte kristlike pühakutega, vaid ka jumala endaga. Sellel partnersuhtel on olnud oma osa nii iga üksikinimese elus ja käitumises, kui ka teatud rollide (teadja, kütt, karjus) jaoks.

Loomulikult pole selline suhtetüüp tähendanud inimühiskonna tingimusteta sulandumist metsaga. Tegemist on olnud rangelt piiritleva suhtetüübiga, milles vastavatel usundispetsialistidel on olnud keskne roll. Animeeritud loodustundlikkus ja vastavad tabud on olnud keerukamad kui põlluharijate anastav enesekesksus või loodushirm. Võib tõdeda, et iseäranis keskvepsa kultuuritüübis on see muster 21. sajandini säilinud või mäletatud ning see on kas määramas või vähemalt ilmestamas mitmeid metsaga (või animistliku maailmaga laiemalt) seotud arusaamu ja praktikaid.

\section{Traditsiooniline rahvakultuur}

Karjusemaagiaga seotud tavade ja uskumuste uurimisel ei pääse me mööda vepsa kultuurisituatsiooni laiema määratlemise vajadusest. Rahvapäraste uskumuste maailm eksisteerib kogu aeg ning ilmselt ei leiaks me ühtki iseloomulikku inimtegevuse sfääri, kust religioossus vernakulaarselt puuduks. Mis on iseloomulik vepsa kultuurisituatsioonile 20. sajandi alguses, keskpaigas, lõpus või 21. sajandil, kust meie teemaga seotud aines pärit on? Väidan, et see on just eelkõige traditsiooniline keskkond, mis on vorminud, konserveerinud, kuid eelkõige 
hoidnud ja andnud kogu siinkäsiteldavale fenomenile tähendust, seda ka läbi varasemate sajandite.

Võib argumenteerida, et traditsiooniline ühiskond on ennekõike omalaadne stereotüüpide kogum, mis aktiveerub kaasaegsele (modernsele) inimesele, modernismi tingimustes koorunud fiktiivne maailm koos sellele iseloomuliku tunnustekomplektiga. Igasugune traditsioonilisus kontseptsioonina on seeläbi otsekui teisene konstrukt, mis on võimalik ja tähenduslik ainult läbi kaasaegse prisma. Võimalik, et see ongi nii, kuid seda küllap ennekõike nüüdisinimesele, kellel juba puudub igasugune aistinguline kogemus seoses traditsioonilisega, või kelle jaoks traditsioonilisus ongi tuttav vaid sellest filtreeritud või selle pinnalt konstrueeritud nähtuste - arhiivisäilikute, museaalide, folklooriliikumise, vastavate ümberjutustuste jne põhjal.

Samas on selge, et kindla piiri vedamine traditsioonilise ja modernse vahele on suhteline ja hinnanguline, samamoodi nagu on üpris võimatu eraldada modernset ja postmodernset kultuurisituatsiooni - seda saaks teha vaid kas väga suure üldistuse või ehk ka väga peene detaili tasemel. Meil on võimalik traditsioonilisest kõnelda üksnes aistingu või mingi tunnuste komplekti kaudu. Esimene tee ei tarvitse ilmselgelt olla ühemõtteline, kuivõrd individuaalne kogemuslikkus saab mõistetavaks ikkagi vaid mingi ühise tähendusfooni olemasolul - mida me tänapäeval traditsioonilisega seoses enam eeldada ei saa. Traditsioonilise tunnuseid on üldistavalt võimalik välja tuua võrdluses või vastanduses nüüdisaja modernse maailmapildi ja väärtussüsteemiga.

Kõige laiemalt haaras moderniseerumine Ida-Euroopa talupojakultuure 19. sajandil ning teadaolevalt oli sellel väga palju tegemist just traditsioonilise rahvakultuuri kui ressursiga modernsete rahvuslike ideede sõnastamisel, uue rahvustunde tekkimisel ning seeläbi ka rahvuslikul vastandumisel, isoleerumisel ning kaugenemisel kunagistest juurtest. Soome (ka Rootsi) varasemale vastanduv kaasajastumine kõige laiemate rahvahulkade tasemel leidis aset 20. sajandi alguskümnenditel käsikäes industrialiseerimise, poetoodete, käitumis- ja oskustekursuste ning üldise maitse ja etalonide muutumisega (vrd Lönnqvist 1999: 119 jj). Ka Eestis käivitus see mudel mõningase hilinemisega enne Teist maailmasõda. Nimetatud maades oli aga selle eelduseks juba varem juurdunud, tegelikult juba läänemaailmale iseloomuliku renessansskultuuriga tekkinud individualistlik kultuurimudel, mis olemuslikult kutsus (uutele) valikutele, samuti hariduselu küllaltki hea seis juba 19. sajandil. 
Eestis avanes tee sellele koos sajandeid kestnud (ja olemuslikult pigem kollektiviseeriva) pärisorjuse kaotamisega 19. sajandi teisel kümnendil. Tegelikum individualiseerumine buumina ning traditsiooniliste väärtuste nihkumahakkamine algas sajandi teisel poolel, mil tekkis tegelik võimalus ulatusliku eraomandi - ennekõike oma talumajapidamise - saamiseks-ostmiseks. 19. sajandi protsesside käigus tekkinud individualistlik väärtussüsteem ei lagunenud Eestis ka 20. sajandil nõukogude võimu aegadel, seda vaatamata kohustuslikule kolhooside loomisele ning teistegi nõukogulike kollektiivsete imperatiivide poliitilisele impordile. Kitsamalt karjatamisest kõneldes võib öelda, et 19. sajandiga kadus Eestist ka kogukondlik ühiskarjatamine, andes teed talupõhisele karjapidamisele (järjest enam tekkivatel kultuurkarjamaadel), seega aga ka karjuseinstitutsiooni ja karjuse kui iseloomuliku rolli taandumisele ühiskonnast.

Kui Eestis oli nõukogude võim ühiskondliku stagneerumise soodustajaks ning alanud moderniseerumise pidurdajaks, siis idapoolsete (hõimu)rahvaste juures on olukord teistsugune. Esiteks pole seal kunagi eksisteerinud valgustuspõhist ilmalikku haridussüsteemi ja kirjakultuuri sellisena nagu see oli 19. sajandiks näiteks Eestis. Individualistlikku religioossust pole vististi soosinud eelkristlik rahvausk, veelgi vähem aga õigeusklik kõrgreligioon. Traditsiooniliste väärtuste suurim konserveerija on administratiivmajanduslikult olnud kogukondlik semstvosüsteem, millele on eraomand ning arusaam selle poole püüdlemisest olnud pigem võõras. Kollektiivseid konservatiivseid väärtusi on kinnitanud ja taastootnud ühistöö ühises omandis olnud maadel, kogukondlikud (st kogukonnapõhised) rahvapühad, aga ka religioossus, milles individuaalse suhte asemel näiteks jumalaga on tähtsam olnud otsekui korporatiivne diplomaatia animistliku loodusmaailmaga. Seda ühiskondlikku süsteemi murendas lühiajaliselt vaid 1920. aastate uus majanduspoliitika (NEP) Nõukogude Liidus, millele tehti lõpp kolhooside rajamisega 1930. aastatest alates.

Kui Eestis tõi nõukogude võim kaasa ühiskondliku stagneerumise, siis idapoolsetel rahvastel saame sellest kõnelda vaid osaliselt. Kahtlemata represseeris leninlik-stalinistlik korraldus ühiskonna individuaalsemalt edasipüüdlikumat segmenti - maal jõukamaid talupoegi, kes tegelesid ka oskustöö ja kauplemisega. Iseloomulik repressioonide laine ja osade inimeste rahvavaenlasteks kuulutamine tabas loomulikult ka Vepsamaad. Teisalt istutus kolhoosi- ja artellisüsteem suhteliselt naturaalselt varasemale semstvokorrale, olles inimestele sellisena palju vastuvõetavam kui oli sõjajärgses Eestis. 
Uus nõukogulik ideoloogia asendas oma üldmustrilt ka varasemat kollektivistlikku religioossust, ehkki religioosne antipropaganda ja pühakodade lõhkumine ei saanud olla tolereeritav.

Võib aga kindel olla, et rahvausu seisukohalt ei olnud niivõrd oluline muutunud võimuideoloogia ise, kuivõrd sellega kaasnenud ühiskondlik muutmistöö, mis muuhulgas asus propageerima ka teaduspõhist valgustuslikku haridust, juurutades samas ka uusaegsemat ellujäämis- ja heaolukogemust. Nõukogude võimu puhul võibki rääkida iseloomulikust ühepoolsest moderniseerumisest (vrd Schöpflin 1999: 54), mis tutvustas senisele paikkondlikule elanikkonnale modernse maailma saavutusi ja selle kaasprodukte. Modernsus istutus seeläbi iseloomulikult (st mitte-euroopalikult) traditsioonilisele ühiskonnakorraldusele, segamata viimast eriti. Suurimaks vapustuseks näib Venemaa maaelanikkonnale olevat olnud mistahes kollektiivsete struktuuride (näiteks ka kolhoosikorra) lagunemine, ning sellest tulenev elutegevuse soikumine, elanikkonna hõrenemine ning pikema aja jooksul väljakujunenud rutiinide hääbumine.

Soovides nimetada traditsioonilisele põhjapoolsele maaühiskonnale iseloomulikku, saame tuua välja järgmisi tunnuseid.

- Paikkondlikkus kui midagi sellist, mis on ühelt poolt otseselt seotud suhteliselt piiratud mobiilsusega ning seostub Venemaal nii semstvokorra, veelgi enam aga nõukogude korra ajal kehtinud maaelanikkonna liikumispiirangutega. Paikkondlikkuse mõõde on Venemaal olnud ennekõike just külastu (vn selo), aga ka küla või külaotsa (vps derún ; aǵ) põhine. Selle piiride ületamine on olnud religioosset ja/või sesoonset laadi, seotud ennekõike laatadel käimise ning suuremate õigeusukeskuste (kloostrite) külastamisega. Oma osa on siin olnud ka meeste ulgutöödel. Vepslased on talviti teinud retki kuni Valge mereni välja. Solovetsi kloostrisse (küllap muudessegi) on religioossete tõotuste (zavet) alusel jäetud noormehi lühemateks perioodideks tööle, millega on omamoodi imporditud ja suurendatud kogukondlikku (kõrg)religioosset päritolu väekust. Sarnased retked on täitnud ka kauplemise ja teenimise eesmärki. Põhjavepslased on teadaolevalt käinud ulgutöödel ka Eestis. Paikkondlikkusega on seotud ka

- kogukondlik eluviis, mis (nagu eespoolgi kõneldud) seab esiplaanile kollektiivsed huvid ning markeerib neid ühistel religioossetel külapühadel ning nendega kaasaskäivatel pidutsemistel (guljanije). Pühadel on olnud kindel koht ka kogukondliku heaolu religioossel 
tagamisel läbi kollektiivsete tõotuste (zavet) "tegemise" (s.o nende andmisel-täitmisel). Kuid kogukondlikkus on esil olnud ka muu igapäevase elukorralduse ja töödega seotult. Ühine on olnud töö semstvomaadel, aga ka alepõletamisel. Selle artikli teemaga seoses märgib kogukondlikkust ka karjatamise korraldus ning küla ühiskarja kui sellise moodustumine. Kogukondlikkuse vastaspoolena nii piirkondlikult (muud külad-külastud-kogukonnad) kui ka religioosselt on kõne all "mitteinimliku kogukonnad" - surnud ja animistlikud vaimolendid, kelle elukorraldust on samuti ette kujutatud kogukondliku, mitte individuaalsena. Teisalt on surnud teatud aegadel ja olukordades inkorporeerunud elavatega - hõimkondlikul tasandil. Rituaalsete kontrollimehhanismide abil on lahkunud esivanemaid käsitletud endiselt hõimu osana. Hõimus või suurperes võibki näha üht kogukonna liiki, milles on kehtinud kindel hierarhiline kord.

- Pärimuslikud tõekspidamised erinevad oma iseloomult ja sisult uusaegsetest teaduslik-valgustuslikest seisukohtadest. Need traditsioonilistes žanrides sõnastatud ja edastatud seisukohad on täitnud mitmeid eesmärke. Nad on olnud paikkonna mõtestamise ja sellesse suhestumise vahendid (kohafolkloor), mis on kehtestanud, õpetanud, kandnud ja kinnistanud eetilisi ja religioosseid norme (sealhulgas inimliku - üleloomuliku suhet), hoidnud üleval traditsioonilist väärtussüsteemi tervikuna (kogukondlikkust, hierarhiaid jm). Pärimuslikud tõekspidamised on kombineerunud väljast tuleva kõrgreligioosse ning metropolitaanse infoga.

- Mitte-infoühiskond - väljastpoolt laekunud info on olnud kasin ning traditsiooniline kogukond on suutnud seda kontrollida, seedida ning langetada asjakohaseid otsuseid. Teabetöötluse kese on asunud kogukonnas, mitte väljaspool seda ning uuele teabele antud hinnangud on lähtunud kogukonna väärtussüsteemist, mitte mujalt. Ilmselgelt on mistahes traditsioonilisele ühiskonnale kõige hukatuslikum välispidise uue teabe äkiline või pidurdamatu pealevool, mille tavapärase enesekohase analüüsimisega enam toime tulla ei jõuta. Selle mõju on fataalsem ka perioodiliste füüsiliste kahjustuste (sõjad, haigused, repressioonid) omast.

- Suulisus on informatsiooni korrastamise ja edasiandmise põhiviis. Suuline kultuur on pärimuslike teadmiste, aga ka väljastpoolt tuleva info käitlemisel oluline kaitse- ja konserveerimisvahend. Mõõduka (ka kirjaliku) informatsiooni juurdevoolu kõrval ei tarvitse 
suuline kultuur alluda kirjalikkuse diktaadile, jäädes selle suhtes immuunseks või kasutades seda oma nihkes kõrvalproduktina. Ilmselgelt ei ole kirjalikkus täielikult kunagi traditsioonilisest ühiskonnast puudunud, kuid küsimus on siin just proportsioonides. Karjusekombestik ning loitsutraditsioon laiemalt on iseloomulik näide suulise ja kirjaliku sünkretismist rahvausus. Situatiivselt ja funktsionaalselt saavad suuline ja kirjalik meedium siin oma ülesandeid jagada. Traditsioonilisele kultuurile omane suulisus on ülekaalus aga seni, kuni on esikohal suulisele kultuurile omased informatsiooni korrastamise ja memoreerimise vahendid. Selle taandumisel (koos kirjaoskuse leviku, eriti aga kirjutamisoskuse üldisemaks muutumisega) asub lagunema, marginaliseeruma ja ununema ka traditsiooniline žanrisüsteem.

- Traditsioonilise ühiskonna tähendussüsteemile on omasem informatsiooni suurem vahetus ja väiksem sümboolsusaste. Traditsioonilises kultuuris (ja näiteks selle poeetilistes väljendustes) ei puudu kindlasti kunstiline väljenduslikkus ja poeesia kitsamalt ning ka traditsioonilise ühiskonna elutegevuse ilmingud on vabalt käsitletavad mitmemõtteliste või sümboolsetena, kuid selline tõlgenduslikkus meetodina ei ole traditsioonilisele ühiskonnale esmaomane. Seetõttu on ka justnagu keerulistel, salateaduslikel või tabulistel usundilistel ilmingutel (kui nad mingil kujul teatavad on) konkreetne ja pigem ühemõtteline tähendus, mis on vaba kaasaegse kunstilise väljenduslikkusega sageli kaasaskäivast ähmasusest. Võiks öelda, et ka poeesia roll on traditsioonilises kultuuris pigem täpsustav kui ähmastav, kunstiline kujund toob tähendust lähemale, mitte ei tekita uusi küsimusi. Teispoolsuse või vaimudeilma kohta eri žanrides edastatavad teadmised muudavad selle maailma konkreetsemaks, mitte vastupidi.

- Traditsioonilises ühiskonnas puudub modernsele linlikkusele iseloomulik atomiseeritus. Kuigi inimesed selles on tunnetavate olenditena avatud isiklikele (ka ainukordsetele) kogemustele, reflektsioonidele ja äratundmistele, ei vii see oluliselt väljapoole kollektiivsest traditsioonilisest seletussüsteemist ning vastavatest kontrollimehhanismidest. Ka väga ootamatu ja eriline otsib (nii inimkäitumises esiletulevana või mõne muu fenomenina) teed tagasi tuttavasse seletussüsteemi, mitte ei ava juurdekasvavalt uusi vaatepunkte, väärtushinnanguid, seletusi, mis ei tarvitse olla omavahel kooskõlas. 
Karjusemaagiaga seoses võime siin öelda, et sellealane teadmiste, praktikate ja kogemuste pagas on kindlasti välja kujunenud ülaltoodud kultuuritüübis. Paljudes üksikasjades avalikkuse eest varjulejääva rahvausulise fenomenina ei saa see taanduda mingile lõpuni lahtiseletatavale kokkuleppele, mille detailidest on kõik ühiskonnaliikmed sarnasel määral teadlikud olnud. Kuid iseloomulikult on traditsiooniline kultuur ning sellest pärit rahvaluuleteated allunud traditsioonilisele ühiskonnale omasele kontrollivale üldistuslikkusele, mis väljendub kasvõi seletuste suhtelises selguses ning eri aegadest ja kohtadest pärit teadmiste kattuvuses.

Tähelepanuväärne on kasvõi see, et ka 21. sajandil keskealistelt inimestelt tehtud talletustes ei esine eriti silmatorkavalt teaduslikust maailmavaatest tulenevat skepsist mistahes üleloomuliku suhtes karjatamisega seotud uskumustes ja praktikates. Kuigi moderniseerumine on Venemaal olnud pigem ühekülgne ja nõukogulik, on see siiski juba aastakümnete jooksul toimunud ning selle peatamise või tagasipööramise võimalikkusest ei saa juttugi olla. See tähendab, et vähemalt 20. sajandi keskpaigas sündinud informandid on üles kasvanud juba suhteliselt nüüdisaegses ühiskonnas, milles on oma kindel ja silmatorkav koht olnud kooliharidusel, kirjaoskusel, massimeedial, usuvastasel propagandal jms. Mis aga teeb olukorra tänapäeva Venemaa maapiirkondades huvitavaks, on asjaolu, et koos ühepoolse moderniseerumisega ei ole kadunud traditsioonilisele agraarühiskonnale omased rahvapärased tõekspidamised ja uskumused.

Võib öelda, et need kaks diskursust - traditsiooniline ja modernne - elavad ka tänapäeva paikkondlikes inimestes erilisse vastuollu minemata edasi. Selles võib näha valgustusliku ja rahvapärase elavat dialoogi, aga ka omamoodi isoleeritust erinevates eluvaldkondades. Vepsa keskealise ja vanema põlvkonna informantidega (ka nendega, kes on juba nooruses linna kolinud) kõneldes torkab silma, et rahvausu fenomenidest rääkides (näiteks animistlikud vaimolendid usundilises jutustamises) ei tõtata otsima nende ilmnemisele ratsionalistlikke seletusi. Pigem kirjeldatakse neid nii, nagu nad esinevad (või on esinenud) elavas folklooritraditsioonis ning ollakse agarad tõdema juhtunu kogemuslikku tõepärasust. See annab tunnistust, et kui inimestel endil (näiteks nüüdisaegses linnakeskkonnas) sellised kogemused puuduvad, on nad siiski endiselt mõjutatud lapsepõlves kuuldud asjadest, kandes seeläbi edasi suuliselt levivat või kogemuslikult tõest usundilist pärimust (mis samal ajal ei sega kuigivõrd nende toimimist täisväärtuslike modernse ühiskonna liikmetena - erialaspetsialistide, pedagoogide, teadustöötajatenagi, kõnelemata tavalistest maainimestest). 


\section{Kodu, mets ja muud sfäärid}

Kodu ja mets on kaks olulisemat sfääri vepsa karjusemaagias. Üldisemalt võiks neile traditsioonilises rahvakultuuris lisada veel veega (jõgede-järvedega) seotud uskumused ja uskumusolendid, kellega on kokku puututud peamiselt kalastamisel, samuti kogukonna territooriumist välja ja kaugemale jäävad linnad ja kloostrid, mis on olnud võõra, samas vajaliku ja ihaldusliku üleloomuliku asukoha- ja päritolupaigad. Jutt käib siin nii religioosse kui ka ilmaliku kõrgkultuuri siiretest traditsioonilisse paikkondlikkusse - linlikest tööstus- ja tarbekaupadest, ikoonidest ja muust kiriklikult väärtustatust, millega on otsekui tõstetud oma koduste või kogukondlike pühakohtade usulist potentsiaali.

Ka kodu- ja kogukonna piirkond on sisaldanud argisest suhtetüübist erinevaid kohti, mis on asustatud ambivalentsete animistlike vaimolenditega ja/või laetud iseloomuliku väega. Ühelt poolt käib siin jutt külakabelitest ning (pool-)looduslikest pühapaikadest, samuti kodustest ikooninurkadest ja muudest võimalikest eriliselt märgistatud objektidest, mis on nõudnud erisuhtumist ning olnud vähemalt periooditi seotud mingite tabude täitmisega. Kabelid ja muud kohalikud pühakohad on lisaks kõrgreligioossele kasutusele (näiteks siis, kui neid on võtnud mõnel markantsemal pühal külastada õigeusu papp) olnud ehk veelgi olulisemad maagilise suhtetüübi rakendamisel argistes toimetustes ja vajadustes. Sel moel on ka justnagu kiriklik või õigeusklik omandanud maagilise agentsuse, millega sidemes olemine on tähendanud nii võimalust kui ka ohtu. Nagu on näidanud karjala rahvausu uurijad (nt Stark 2002: 178-183), leidub läänemeresoome rahvaste rahvausus näiteid kabelist või ikoonist saadud hädade ja tõbede kohta, kui on eksitud nendesse respektiga suhtumise nõude vastu, mida on saanud annulleerida maagiliste protseduuride ja praktikate abil.

Maagiline negatiivne mõju on olnud ka mahajäetud majadel, küllap seoses rahuldamata majahaldjate või surnud omaniku endast märkuandmisega eriti ööajal. Sarnastest kohtadest ohutu möödumine on eeldanud näiteks palvesõnade lausumist. Rahuldamatust mingites olukordades või aegadel on võinud üles näidata ka majapidamispiirkonda asustanud vaimolendid (vt eriti Vinokurova 2006: 256-258). Ilmekamad on iseäranis saunas ja laudas elava vaimolendi tegevuste kirjeldused. Üldjuhul ei tähenda vaimolendi nägemine head. Saun kui iseloomulikult kahetise tähendusega koht on inimeste kasutada 


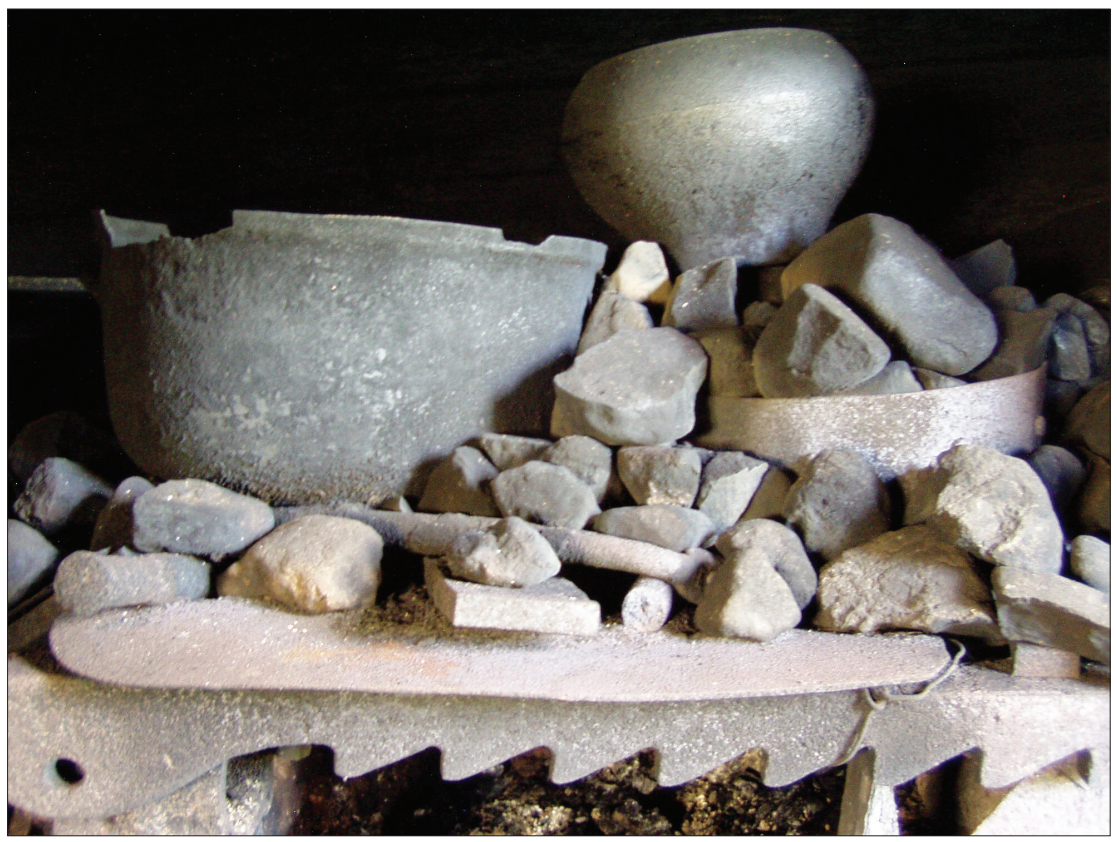

Foto 2. Vepsa suitsusauna keris. Pecoiĺ. Madis Arukase foto 2007.

olnud ennekõike valgel ajal ning seotud siirderiituste ja korrastavate tegevustega. Sünnitamine või pruudisaun on tähistanud sotsiaalset üleminekut ühest staatusest teise. Ravitsemine, aga ka pesemine on olnud inimtervikut korrastavad tegevused, mida on varem läbi viidud omamoodi rituaalselt. Nii ravipraktikad kui ka pesemise viis on sageli rõhutanud inimkeha sümmeetriat või selle markeerimist (näiteks raviprotseduurilised "mõõtmised"). Pestud, muditud ja viheldud on inimfüüsise osi kindlas järjekorras, otsekui taastades perioodiliselt käestminevat algkorda. Otse loomulikult on neile tagavustele fooni loonud paiga - sauna - eriline staatus, kus inimene on külalisena oodatud vaid ajal, mil see ei ole "teise" meelevallas. Ootuspäraselt on tulnud saunahaldjate suhtes näidata üles aupaklikkust ja tänulikkust:

Külbetis ved lähtöd-ka, sanod: passibo ižändäižed-emäǵeized, pesedamöst-vastoimöst; lähtöskand ka ühtnägóoi sanod muga. 
[Saunast minnes ütled: aitäh isandakesed-emandakesed, pesemast-vihtlemast; minnes nii kohe ütled.]

(L. K., Ladv, Leningradi oblast, 1981; RKM Mgn II ${ }^{1}$ )

Vaimolendite kiuslikkus tuleb eriti esile koduloomadega seotud juttudes ja uskumustes. Lauda- või õuehaldjas on võinud mõningaid loomi kurnata kuni lõppemiseni. Peamiselt on seda põhjustanud kodulooma mittemeeldivus vaimolendile, täpsemalt vale värv (Vinokurova 2006: 258). Loomade-lindude hea käekäik majapidamises on tagatud olnud ennekõike siis, kui nad on olnud laudahaldjale soositud karva-näiteks mustad või heledad. Värvuse tähtsus on olnud ilmselt teisejärguline külakarjas, mis on olnud juba karjuse vastutusalas. Samas on karjus pidanud teadma kõikide ühiskarja loomade karva, mis on olnud osa ta maagilisest kompetentsist metshaldjatega suhtlemisel (vrd Fedosova 2010: 134; Durasov 1989: 270).

Nagu saun, ei ole inimeste täielikus meelevallas olnud ka majapidamine ise. Majahaldja olemasolust on teadlik oldud, ta välimust ja sugu on teatud, majahaldja ilmutamises või tema lahkumise nägemises on nähtud halba märki. Majahaldjat on uues majas tervitatud loitsuvormeliga, milles on palutud tema soosivat suhtumist uutesse elanikesse. Selliseid loitse on teatud üleüldiselt ning neid mõistavad vepsa informandid öelda ka tänapäeval, näiteks:

Ižandaized, emagaized, dedaižed, babaižed, lapsuded, vellíuded, sõzaruzed, primkad tide kanza mid, minun lapsid, pidaga kui ičetoi, (neljad čogaiž kummardade)

[Isandakesed, emandakesed, taadikesed, eidekesed, lapsekesed, vennakesed, õekesed, võtke enda hulka mind, minu lapsi, hoidke kui endi omi, (ja nelja nurga poole kummardada)]

(V. L., Kurb, Leningradi oblast, 2008) 
Sellised vormelid ei ole olnud kellegi eest varjatav salateadmine nagu seda on kasvõi karjuse- või raviloitsud. Vepsa traditsioonilises kultuuris on need kuulunud iga inimese kohustuslikku repertuaari samamoodi, nagu peab tõsiseltvõetav kristlane oskama kõige elementaarsemaid palveid. On tähelepanuväärne, et kui nõukogude aeg võorutas terve põlvkonna vepslasi kristlikust palverepertuaarist, ei peatanud see sedasorti maja- (aga ka metshaldjale) adresseeritud vormelite kasutamist ja edasiandmist. Vastava pöördumise abil on võimalik olnud majahaldjat ka elukoha vahetamisel endaga kaasa kutsuda. Järgnevas näites seletab informant, miks uues kojas majahaldjaga kontakti võtta tuleb:

Tariž pakita, miže ižändäižen, emägäižen..., hot mäned hot' vi... perthe mičheäine, nu-ka voidas $i$ anta magada, ed magad aigoine, a paned-tö, ka sanud-ižändäižen, emägäižen, pästkät mindei öks, bohaslovigat mindei magata - silloi ni midä uniž ed ńäged $i$ magadad. [---] Naprimer tännä tuližin minä-da, sijäle pandas, nu-ka sanun - ižändäižen, emägäižen, pästkät mindei öks, bohaslovigat mindei magata - silloi uniž ed nääge ni midäd $i$ magadadki. A ku muide pannet, ö-ka, voidaz... $i$ anta magata. [---] Udenki stroid-ka, tariž pakita. Udenki-ka stra..., pakita tariž.

-A kut?

Ka mugažo. Mise ižändäižen, emägäižen, pästkät mindei netśe eloile, bahaslovigat mindei, et mini eläda, netsit.

[Peab paluma, et isandake, emandake..., kui lähed mõnda majja, võib olla, et ei lasta magada, ei maga võib-olla, aga heidab magama, siis ütled - isandake, emandake, lubage mind ööseks (siia), õnnistage mu und - siis ei näe mitte midagi unes ja magad. [---] Näiteks tulin siia, heidan asemele, siis ütlen - isandake, emandake, lubage mind ööseks (siia), õnnistage mu und - siis unes ei näe midagi ja magadki. Aga kui niisama heidad, siis võib... ei lasta magada. [---] Kui uue (maja) ehitad, peab paluma. - Kuidas?

Niisamuti. Et isandake, emandake, lubage mind siia elama, õnnistage mind, et saaksin siin elada.]

(D. F., Ladv, Leningradi oblast, 1981; RKM Mgn II) 
Loetletud sfääride kõrval on suur tähtsus olnud ka surnuaial ning seal asunud surnute kogukonnal. Matuse- ja mälestuskombestik, iseäranis aga monumentaalne ja poeetiliselt keelelt väga väljaarendatud itkurepertuaar väljendavad lahkunute suhtes suurt respekti, samas on nende esmane ülesanne kontrolli hoidmine elavate-surnute piiril, nii lahkunute heaolu kindlustamine kui ka nende soovimatu ilmnemise ärahoidmine maagilis-puhastavate, ennekõike aga just itkudes väljendatud diplomaatiliste vahenditega. Varasemates ettekujutustes on surnute asukoht olnud maa all, kus on jätkunud tavapärane hõimkondlik elu igapäevaste toimetustega. Kujutlust sellisest allilmast on esitanud üks vepsa tedai veel 21. sajandil (Arukask 2009: 139). Surmailma minemisel on oluline olnud lahkuja rahulolu ja muuhulgas hea füüsiline vorm, mis on taganud ta olemise kvaliteetse jätku surmajärgses elus. Loomulikult on vepslastele tuttavad surmajärgse hinge lahkumisega seotud perioodid, mida on markeeritud vastavate rituaalidega mälestusaegadel. Sarnaselt teistele loetletud sfääridele on suhe surnutega olnud kahepoolne, kus elavate poole pealt on keskne roll olnud itkejal kui spetsiifilise kommunikatsioonikeele valdajal. Kujutlus põrgust ei ole vepsa rahvausus ülemääraselt levinud, ehkki kloostri- ja kirikukristluse mõjul on vastav teadmine loomulikult tuttav.

Iseloomulik ja samas komplitseeritud teemavald on ülailma taeva paradiisiga seotud temaatika. Nagu Põhja-Venemaa teistegi rahvaste ettekujutustes, on taevas olnud jumala asupaik. Jumala kuju oma tegevuslikkuses (müristamine) on võinud olla seotud ka Nikolai Imetegijaga. Rahvapärases (st mitte kõrgreligioosses) õigeusus ei saa me aga nimetusega "jumal" tähistatud uskumusolendis näha üksühest kattuvust kristliku isa-Jumalaga. Jumal on esindunud mistahes ikoonides (jumalaine), samas (nagu juba nimetatud) on ikoonide toime olnud ambivalentne ning suhe nendesse mitmeski mõttes maagiline. Rahvausu jumala mehhaaniline samastamine kõrgreligioossega tekitab paratamatult olukorra, kus palju vernakulaarselt iseloomulikku lihtsalt "tõlkes kaduma läheb". Põhjapoolsete kütikultuuride taevasest valitsejast on kristlike joontega jumal kujunenud alles viimastel aastasadadel (vrd Siikala 2012: 431). Looduslikus pühapaigas "jumalale" tõotusandi (zavet) tehes võib sünkretistlikult esindatud olla nii kõrgreligioosne kui ka rahvapärane (eelkristlik) ettekujutus.

Peatumata sellel probleemil pikemalt olgu vaid öeldud, et näiteks usklikkus ja "õige inimese" (riśtit) kontseptsioon on vepsa rahvausus seostunud kõigi animistlike vaimolendite ning kristlike (või kristlikku 
päritolu) pühakute ja Jumala austamise, mitte ühe poole diskursiivse eristamise või soosimisega. Vaimolendite ambivalentsus ei ole vepsa rahvausus viinud nende sel määral demoniseerumiseni nagu paljudel teistel põlluharijarahvastel. Samas ei näi taevaste jõududega läbisaamine või maagiline argumenteerimine siin nii iseenesestmõistetava või võimalikuna nagu see on teiste sfääride ja nende esindajate puhul.

Vaatamata kodusfääri asustatusele erinevate respektivajavate vaimolenditega, on see ühtlasi olnud ka inimeste asu- ja turvapaik. Koostöös majahaldjaga on seda kaitstud võimalike maagiliste ohtude eest. Kalendaarses tähtpäevakombestikus on tuttavad praktikad, kus markeeritekse majapidamise piire, mil koju on toodud külapühal või kaugemal õnnistatud ohutisi (oksad, munad, vesi jne). Samavõrd tähtis on olnud pidada silmas, et majapidamisse ei satuks (salaja tooduna) halva maagiaga laetud esemeid, mis võivad avastamata jäänutena mõjutada fataalselt inimeste õnne, tervist, sigivust. Ka 21. sajandil ei ole informantidele võõrad maagilise ärategemise lood ning näited ühe või teise inimese või perekonna luhtunud elust, mida on varjutanud pahatahtlik pinge, mille on tekitanud kellegi teise sihipärane (vastu) tegutsemine. Kodu pole rahvausus olnud tingimusteta hea paik. Selle terviklikkust on tulnud pidevalt tagada usundiliste (vastu)võtetega.

Alekultuurile iseloomulik side metsaga pole siiski tähendanud sellega samastumist, vastupidi: metsa ja inimsfääri vahel on valitsenud piiritletus, piiri hoidmine on omakorda olnud esmaoluline inimliku identiteedi ja inimeste turvalisuse seisukohast. Piiriületused selles vallas on olnud iseäranis ohtlikud ja anomaalsed, metsa eksimine on tähendanud võõrasse meelevalda sattumist, sellesse kadumist või sulandumist, mille tagajärg on võinud olla hukatuslik. Mets (samuti veemaailm) on olnud omalaadne inimtegelikkuse paralleellookus, mida on mõistetud sarnase kaudu (metsaühiskonna hõimkondlikkus, hierarhilisus jne), kuid selle koha sisu on olnud olemuslikult erinev, eristav, võõristusttekitav. Metsapiirkonna rahvaste folkloorse repertuaari iseloomulikumaid teemasid on kahtlemata eksimislood, aga ka eksiolekust pääsemise tehnikad ja vastavad lood (vt nt Heikkinen 1994: 150-154).

Rahvajuttudes on eksimise või kaotsimineku põhjus võinud seisneda kas inimese enda hoolimatus või ettevaatamatus käitumises, metshaldjate pahatahtlikkuses, aga ka juhuslikkuses - sattumises metsa olemusliku anomaalia meelevalda. Viimane on võinud olla seotud või seletuda ka kahe esimese põhjusega. Halva või ebakohase inimkäitumise karistajana on metsal olnud otsekui moraalivalvuri 
roll. Rahvajuttudes pole siiski metsa kui eksitaja kohta hinnanguid antud. Eksimise põhjus on juttudes peitunud ikkagi inimkäitumises, mõnes ekslikus teos. Harilikult on niimoodi karistatav olnud metsas vandumine või metsamineja hurjutamine kojujääja poolt. Elulised on lood, kus marjule kippuvale tütarlapsele, kes ei malda tõsiselt võtta vanema käsku jääda koju, öeldakse õnnistuse asemel kaasa vandesõna (selliseid tõsielulugusid on mul ekspeditsioonidel mitmel korral kuulda õnnestunud). Metsas eksimine on seejärel seaduspärane, mets sellistes juhtumistes aga kodus ettemääratud sündmuse toimumiskoht. Dualistlikuma vaatepunkti järgi võib siingi näha otsesemat skeemi vandumisega on mineja antud otseselt halva meelevalda, mitte hea kaitse alla.

Metsas näib seega kehastuvat halb potentsiaal, isegi soov halba teha. Selle vastu on kasutatud ka spetsiaalseid loitse. Lauri Kettunen on oma eelmise sajandi alguse lõunavepsa keelenäidete seas publitseerinud näiteks sellise loitsuteksti muu hulgas ka metsast tulla võinud häda vastu (metsan višketišes, Kettunen 1925: 143-144):

Nouzen mä rabboožee aigašti i pezeme vauktašti, $i$ lähten mä ukses ukshe $i$ väroos väroožhe, $i$ lagedha peüdhe $i$ vihandha romhu, $i$ vihandas romus ištub vauged ukoone, šuukuune bardaańe, $i$ vaškšet_silmad $i$ raudaažed hambhad i rahaažet_kinded, $i$ otab nétii rabaabožiaa stiopaapä pričiam_prizoran $i$ osudan $i$ rossudan $i$ hondon pahan tegotišen, $i$ hondon pahan laiitišen $i$ rodiitélskeian došpeskan $i$ vezitégotišen $i$ metsan_višketišen i tuliaažen tégotišen i dvorovikaa tounitišen, ougotab hänen iliiči ihtsäs mas i zelenskeiaha maha $i$ kiviižhe romhu i netit_časus $i$ ńetid aigassaa, $i$ ot niń $i$ do véki vékof.

[umbkaudu: Tõusen mina, Jumala ori, varakult ja pesen puhtasti, ja lähen ma uksest ukseni, välisuksest välisukseni, ja lagedale väljale ja haljale heinamaale, ja haljal heinamaal istub vanake, siidine habe, ja vasksed silmad ja raudsed hambad ja hõbedased küüned, ja võtab sellelt Jumala orjalt Stjopalt külge hakanud vaeva ja (kohtu)otsuse ja viha ja halva paha haiguse, ja halva paha puuduse ja vanematelt tulnud halva ja veest tulnud vea ja metsast saadud häda ja tuulest tulnud tõve ja õuehaldja pandud õnnetuse, saadab selle üheksa maa taha ja rohelisse maasse ja kivisele heinamaale ja sellest hetkest ja sellest ajast, ja nüüd ja igavesti.] 
Halvale jäljele sattumise seletus viitab sellele otseselt - metsas on otsekui mingi endasseneelav potentsiaal, mis võib inimest tabada kõigele vaatamata, juhuslikult või ettekavatsetult. Siiski ei saa metsa vepsa rahvausus võtta kristliku ürgkurjusena, mille puhul aitab vaid religioosne vastuvägivald. Selle tunnistuseks on vepsa informantide teiselaadsed praktikad metsaminekul - lepituse, aga ka isegi soosingu otsimine. Nagu majahaldja puhul, oskavad vepslased metshaldjatele adresseeritud palveloitse, mida metsaminekul on tulnud lugeda ning milles on palutud metsa poolt hoidmist ja tuge - metsasoleku ajaks. Sellise eelduseta soosingule ei saa kuidagi läbi ka jahipidamine ning vastav maagia. On ka iseäralike personaalsete rituaalide kirjeldusi, kus marjule või seenele läinu pöördub puude (st metsa) poole palvega saada jõudu ja tervist. Alloleva teksti esimeses pooles on juttu tavapärasest metshaldjatega suhtlemisest ja neilt seene-marjasaagi palumisest, seejärel aga kasepuult abi palumisest:

Ižändaižele... mänen, da tesharad nakka-no, tesharad nakkano, tesharad-dorogad mändasoi.. sižutamoi... mecižändaižed, mečemägaižed, pästkätei mindai metžaiheže töiä, ankatei mińoi marjoid, griboid, ankad minei terhud, väged... no, mińa kaika ljudan, kaika antasoi mińei, rissitud - kui sa ljusid griboid da śened? ljusin mińa ičein tahoil, lähtežkanden, mecas koiranke kaika mińei... koir... mikšed-ni suhrižed libo kandoižele, lindoižele da... likeidam, śüöndad... emägeižele da ižändaižele... mecaspäi lähton, mesta tulon, sille tahole, mesta, kumardamoi: spasibo ižändäižed, emägaižed, andoite minei terhuh, andoite väged, andoite marjoid, griboid. Spasibo, kalliš sińä minun armaz mecaine, kaika ńinga sanun. mecas kävelen, da surdun, koivud da sured, sištazoi, mägež-da mogo, miš krõšus libuda... koivužen sebädan - armaz sińä koivuine, lehedad sinun leh'toižed, tihedad sinun okžaižed, armaz mińun sinä, puhud, anda sińä minui terhud, anda väged, abuda tämbei minei kode sadhas. Noh, vei minei čoma, mecäs kävelen ka, mińa voin sile, en läžu, kodiž kaik aig läžuna, a mečäs, siga prijatno kävelda

[(mets)isandale (ütlen)... lähen, ja teeharud niimoodi, teeharud niimoodi, teeharud-rajad lähen, seisatan... metsisandad, metsemandad, lubage mind teie metsa, andke mulle marju, seeni, andke mulle tervist, jõudu... noh, mina kõike leian, kõike antakse mulle, inimesed (küsivad) - kuidas sa leidsid marju ja seeni? Leidsin mina oma kohtadest, hakkan minema, metsas, 
koeraga kõik minu... koer... mõned kuivikud (?) kas kändudele, lindudele ja... lõikan, söödan... emandale ja isandale... metsast tulen, (teatud) kohale tulen, sellele kohale, paika, kummardan: aitäh, isandad, emandad, andsite mulle tervist, andsite jõudu, andsite marju, seeni. aitäh, kallis sina minu armas metsake, kõik niimoodi ütlen. Metsas käin, ja väsin, suured kased, peatun, selline mägi (?), et üles (?) ronida... kallistan kaske - sina armas kaseke, värsked (on) sinu lehed, tihedad su oksad, armas (oled) sa mulle, (???), anna sina mulle tervist, anna jõudu, aita mul täna koju jõuda. Noh, (?) mind kenasti, metsas (kui) käin, (siis) seal ma suudan, ei põe, kodus kogu aeg põen, aga metsas, seal on hea käia.] (M. A. Ladv, Leningradi oblast, 2010)

Kõik see iseloomustab metsa kui partnerit, kellega ka lihtinimesel on võimalik asju ajada. Rahvapärases juturepertuaaris torkavad siiski rohkem silma lood, mis on seotud metsa ohtlikuma pale ja vastavate juhtumistega. Neil puhkudel on olnud vaja juba spetsialisti abi. Igasugune (metsa) kadunute otsimine, olgu kadujaks inimesed või koduloomad, on olnud teadjate tööpõld (vrd Heikkinen 1994: 154 jj; Salve 1995). Näib, et kadumine kui selline üldse (ka mitte metsa) on olnud metshaldja "tegevussfäär" ning neil juhtudel on teadja asi olnud astuda haldjaga dialoogi - eeldusel, et tal on alust kahtlustada konkreetses kaotsiminekus metsa.

Teadja "töökohtumised" metshaldjaga on olnud seotud üleloomulike kogemustega metshaldja saabumisel kohtumispaika inimliku ja metsiku piirimail (metsaservas, teederistil). Kirjeldatud on tohutut tuult ja puude paindumist (vrd Salve 1995: 372), milleks teadja on pidanud kindlasti valmis olema. Kui kadumaläinute vabastamise palve on alusetu, mõjudes nii süüdistusena, võib see kaasa tuua otsese ohu teadja elule. Positiivse lahenduse korral on kadunud loom või inimene metsavallast vabastatud ning ta on saanud koju pöörduda. Metsa eksitavat ja endasse haaravat efekti on seletatud omamoodi nähtamatusega, millega eksinu-kadunu kaetakse nii, et ta otsijatele nähtamatuks jääb (Holmberg 1923; Pentikäinen 1987: 145-146; Salve 1995: 364; Järvinen 2004: 207-211; vrd ka Moroz 2001: 246-247). Samal ajal viibib otsitav nagu mingis teistpidises-teistsuguses reaalsuses, millest tal omakorda puudub väljapääs, lõpuks ilmselt ka teadlikkus või tahtlikkus välja pääseda. Abi on olnud efektiivsem alati võimalikult kohe pärast eksimist. Mingi perioodi järel (näiteks 9 päeva, vrd Mišurinskaja 2000a: 68) on kadunu loetud juba lõplikult metsa meelevalda jäänuks. 
"Lihtsamatel” või õnnelikumatel juhtudel on pääsemisele võinud kaasa aidata enda oskuslik käitumine. Mets kui varjav või varjutav maailm on pidanud eksinule läbinähtavaks muutuma, "selginema". Sattumine metsa teispoolsusse on võinud olla ajutine, sealt pääsemiseks on aidanud ümberpööratusele ümberpööratusega vastamine riiete ja jalanõude teistpidi selga-jalgapanek pärast eksimist, enese ajutine alastivõtmine. Selliste võtete abil on end vabastatud metsa varjavast, segiajavast, eksitavast toimest. Ümberpööratus on toiminud ka "jälgede keeramisel". Neil puhkudel on abi olnud sellest, kui kaduma läinud looma või inimese poolt teele jäetud jälg pööratakse mehaaniliselt (näiteks labidaga) vastassuunda - metsa suunas minev jälg kodu suunas.

Mets on paljuski sarnane teistele otsese inimtegevuse välistele või ka selle sisse jäävatele animistlikele sfääridele. Sellegipoolest näib mets mitmeti markantsem. Selle esimene põhjus on asjaolu, et vepsa asualadel on mets loodusmaastikuna valdav. Pääsud ühest inimasulast teise, teed kalastamiseks oluliste veekogude juurde, alepõllumaadele on viinud läbi metsade. Järved, sood, alemaad, kõnelemata seene- ja marjakohtadest, ongi asunud metsades ning metsa võib seega käsitleda domineeriva maastikuelemendina. Metsale on alternatiivi pakkunud vaid suuremate veekogude kaldaäärne asustus - näiteks põhjavepsa Äänisjärve-äärne asulate ahel, samuti jõgede (nagu Ojat) ääres paiknevad asulad.

Teiseks on mets olnud inimtegevuse olulisemate ressursside allikas. Ilma metsaste karjatamiskohtadeta poleks loomapidamises läbi saadud, samuti nagu põllumajanduses on sajandeid domineeriv olnud alemaade tegemine. Aletamine-kalastamine on perioodiliselt suunanud inimesed metsa elama. Kogukondadel on metsades, alemaade naabruses olnud kergemad hooned, kus soojemal ajal (alates kevadisest alepõllundusperioodist) on täiskasvanud võinud elada nädalaid, samal ajal, kui lapsed ja vanemad inimesed on külas hoidnud muud majapidamist. ${ }^{2}$ Nii võime vepsa traditsioonilises eluviisis näha metsaga kombineerunud kultuuritüüpi, mis baseerub vastastikusel koostööl.

Ka karjatamises ja sellega seotud uskumustes ja maagias tuleb näha eelkõige kooperatsiooniprintsiipi. Karjatamine on vaieldamatult üks kesksemaid, aga ka keerukamaid komplekse, milles inimliku ja mitteinimliku, kodu ja metsa sfäärid ning huvid kohtuvad ja põimuvad. Eelpool metsaga seostatud üksikasjad (kadumine, nähtavusnähtamatus metsas, vaimolenditega läbisaamine ja nende soosingu saavutamine, iseäranis aga inimpoole esindajate iseloomulik agentsus) 
tulevad kõne alla ka karjatamisega seotud praktikates. Karjatamisel ei ole suhe metsaga olnud kunagi personaalne (nagu näiteks lihtsal marjakorjamisel või metsast kütte või tohumaterjali varumisel), vaid kogukondlik - rolliliselt kesksel kohal olnud karjus on esindanud nii materiaalselt kui maagiliselt inimkogukonna huve, olles samal ajal osaliselt "teine" ka kogukonna silmis.

\section{0. sajand ja olude muutumine}

Tänapäevaks on loomapidamine vepsa külades peaaegu välja surnud. Ojati-äärsetes külastutes on tavaline, et leidub vaid 2-3 majapidamist, kus veel lehma peetakse ning heina tehakse. Ette tuleb ka üksikuid eraettevõtjate või kollektiivmajapidamiste suurkarju (viimastel aastatel on sellist näha olnud Vilhala kandis), mida saadavad karjused. Siiski on karjatamine kui kunagine keskne tegevusvaldkond oma endisel kujul suhteliselt taandunud, sellega koos on muutunud ka vepsa külade ja ümbruskonna maastikuline ilme: hein kasvab omasoodu, karjamaad võsastuvad. Viimane sellesuunaline muutus leidis aset koos kolhooside likvideerimisega 1990. aastatel. Nõukogude kord, mis oma ateismipropagandaga lõpetas kirikute ja kabelite tegevuse, ei küündinud tegelikult kuigivõrd paljude muude rahvausu praktikateni. Nii säilis ka kolhooside ajal tavapärane karjusemaagiale toetunud karjatamisviis koos selle juurde kuuluvate karjusepoolsete rituaalide ja uskumustega. Karjusetööd võidi edasi anda põlvest põlve, mis kindlustas maagiliste teadmiste ja praktikate jätkumise.

On siiski alust arvata, et karjatamine tõi kolhoosikorra tingimustes endaga kaasa tervikpildi muutumise ja vaesustumise. See puudutab just perenaise ja kodu rolli oma loomade saatmisel külakarja, mis oli karjatamise juures iseloomulik. Samas ei lõpetanud nõukogude võim täielikult kodust loomapidamist, seega kestis ka perenaise institutsioon ja eriline suhe lehma loomapidamisel edasi. Kui kolhoosikarju hoidsid professionaalsed traditsioonilised karjused, vajasid nad oma maagiliste taigade toimetamisel ka teadjate abi. Tedai-institutsioon säilis 20. sajandil seega suhteliselt stabiilselt seoses kogukondlikult vajalike toimetuste - ravitsemise, kadunud asjade, inimeste ja loomade otsimise, armumaagia ning samamoodi ka karjatamisega. Pole vale väita, et teadja roll 20. sajandil mitte niivõrd ei marginaliseerunud, kuivõrd spetsialiseerus. Arstiabi paranemise ja professionaliseerumisega ei saabunud lahendusi kõikidele tervisehädadele, seletamatu 


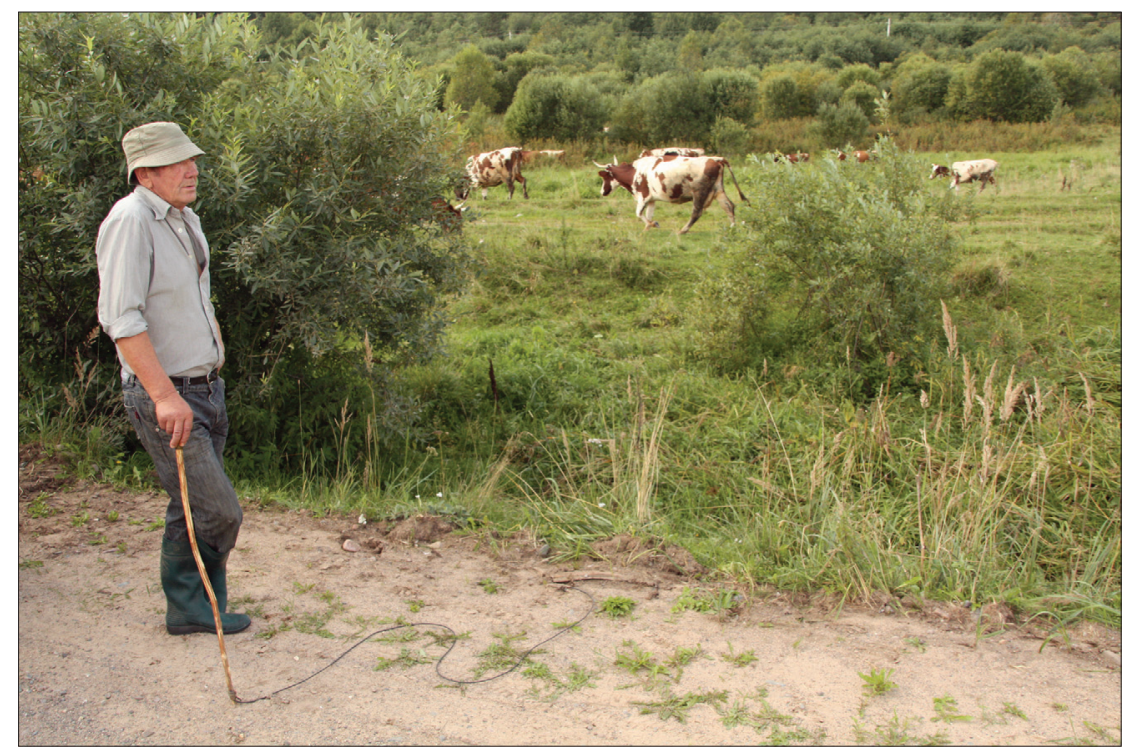

Foto 3. Loomade karjatamist tuleb Vepsamaal ette veel ka tänapäeval. Vilhal. Madis Arukase foto 2011.

vastu abi otsimisel on tee viinud ikka teadja poole (vrd ka Kristi Salve artiklit käesolevas kogumikus).

Tedai-institutsiooni taandumise põhjusena võiks näha mitte niivõrd vajaduse, kuivõrd suhtumise muutumist - nii on modernse ees taandunud paljud traditsioonilisele ühiskonnale omased jooned. Inimese käitumist ei määra mitte niivõrd ratsionaalne või teaduslik vaateviis, kuivõrd suhtumine, mis ei väärtusta enam üht või teist praktikat või seletussüsteemi. Seoses karjusemaagiaga ja teadja osaga selles on kahtlemata oluline olnud ka süsteemi ja kogu maamajanduse järsk muutus 20. sajandi lõpul, mis on maal sisuliselt kaasa toonud loomakasvatuse hääbumise.

On väga kaheldav, kas loomapidamisega seoses võiks siin midagi tagasi tulla. Asi pole mitte ühes elatusalas, vaid kogu eluviisis ja suhtumiskultuuris. Tänapäeva talunik, kelle eesmärgiks on tootmine ja majandustegevus, pole endine talumees semstvos, kelle suhe oma keskkonnaga oli palju rikkam ja mitmekesisem, ühtlasi ka konserva- 
tiivsem ja tundlikum. Tänapäevast maakapitalismi (ükskõik millises riigis) pole mõtet võrrelda kunagise rolliderohke maaühiskonnaga, kuhu teiste seas kuulusid ka meid siin huvitavad iseloomulikud traditsioonilised eristaatused - karjus, teadja, peremees ja -naine jne.

\section{Karjuse tegevus informantide silme läbi}

Saamaks midagi teada tänapäevaks suhteliselt tahaplaanile jäänud rahvausu fenomenist, peab küsitlussituatsioonis omama ennekõike ise mingeid eelteadmisi jutu juhtimiseks ja üksikasjade täpsustamiseks. Päris kindlasti ei ole karjusemaagia aines, mis välitööolukorras esimeste teemade seas välja tuleks. Probleem on siin mitmetahuline. Vaieldamatult teadvustab iga keskealine ja vanem vepsa/põhjavene informant endale karjuse erilisust - kui mitte rolli, siis vähemalt isiksusena - nagu ta teda omal ajal hoomanud on. Ootuspäraselt teataksegi karjust tema põhitegevuse kaudu - karjatamise üldjoontes kirjeldamisega vajadusel probleeme pole. Karjuse rituaalidest võidakse kõnelda seoses jüripäeva toimingutega karja rituaalsel piiramisel, mida on pealt nähtud. Asjatundmatul uurijal võib infosaamine sealtmaalt ka lõppeda ning kogu materjal jääda etnograafilise kirjelduse tasemele. Karjus on sel juhul vaid ühe elatusala osis, mitte iseseisva folkloristliku, rahvausulise kompleksi keskpunkte.

Informantide mäletamis- ja memoreerimisviisi võib võrrelda kärjelaadse kogumiga (vrd Raudalainen 2001: 66), kus mingi teadmisega külgnevad teise teadmise servad - nagu meeanumakesed mesilaskärjes. Samas ei tarvitse üks teadmine viia automaatselt külgnevale, vaid informatsiooni osad võivad jääda üksteisest isoleerituks - kui uurija ei tea või ei märka informanti sillastusele juhtida. Õnnelikel juhtudel võib informant ka ise "kullasoonel" edasi liikuda, kuid ka siin on oht, et pikka arengut ei toimu - kui uurija ei suuda kooruva materjali väärtust tajuda, seda ära tunda ning katkestab oma teadmiste piiratuse tõttu teema.

Karjuse tegevuse kirjeldamist võib kuulda ka juhtumisi - näiteks kõneldes välitöödel traditsioonilistest külapühadest, muuhulgas ka jüripäevast. Tavaline kirjelduspilt kujutab siin karjust sõela asetatud maagiliste esemetega - ikoon, terariist jms külaserval karja piiramas ümbarduzt läbi viimas (vrd Guljajeva 1986: 180; Vinokurova 1994: 75, 1988: 14 jj; Fišman 1986: 192; Moroz 2001: 247-248 jt). Jutuks võib tulla ka perenaise vastav tegevus loomade kodunt külakarja andmise 
eel - eriti kui informant seda ise teinud on. Üldjuhul siitmaalt jutt ka lõpeb, kuna kogukonna tavaliikme "kaamerasilm" üldjuhul karjusega kaasas ei käi ning tema tegemiste siseringi ei küündi. Kogukonna tavaliikme perspektiivist saadav informatsioon on reeglina katkendlik:

- Kut nece lehmad pästäs?

Ka lehmad pästäs, nägid, mi ka jumalaižen paneme, nece, ningada siga jumalaižen-se heitame, pästäme. Esmeisen kerdan-se tanhupei tuespissa.

- A minne birb...?

Birbvičeisansegi andami... mińel vośil $i$ ole paimet mide deru$n a s-k a$, iče paimendame, a edu ka andami paimnele ningoman vičeisen, sebered nicoided o meda.

- A mit nece paimen radob?

A paimen, hän muražmättoižehe.. - tedäte murheižen? - muražmättoižehe pa'ab sigä ka, kut nene murheižet ühtes kohte, näit, elätäs, muga nece stadaine elägähä, silloi ka lehmized ümbärdäb ninga ümbride...

- Ümbardab? Ak?

Ka. Jumalaiženke, edu ka kaika muga, a nü̈de iče paimendamika. Domna, nakka da se paimendela. Nece ümbardelam, muité ka em me ümbardol.., edu ümbardzimi kaik... paimńele.

- A nece Domna paimen oĺ?

Domna oĺ paimen, üheža kezad paimensi. Eśki ak oli. Üheza kesad. A śid Johor eń tea kuverdan kezad paimenśi. Da muga.

- A miń täht nened ümbardada?

Ka miš-e, nä̈ged, zveride täht-da.., i.. zver-sa koskadiš, händikas, tak, hän sin täht ümbardi. Jumalaiženke.

- Ka, ka, i hädikas i kokseta?

Ka, miše händikas i kožketeiž, nened živataižed.

[- Kuidas lehmi välja lastakse?

Lehmad lastakse..., näed, me paneme ikooni, niimoodi, seal ikooniga laseme. Esimesel korral laudast tulles.

- Aga oks...?

Urbenädala oksa anname... eelmisel aastal ei olnud meie külas karjust, ise karjatasime, aga enne andsime karjusele selle oksa, sellised seltsid on meil (???).

- Aga kuidas karjus töötab? 
Aga karjus.., ta paneb sipelgapessa - teate sipelgaid? - selle (ümbarduze), nii nagu sipelgad koos elavad, nii olgu ka kari koos, siis ümbardab ka lehmad, käib ümber...

- Ümbardab? Naine?

Ja. Ikooniga, enne kõik niimoodi tehti, aga nüüd karjatame ise. Domna, see, näed, karjatas. See tegi ümbarduzt, niisama me ei ümbardanud, varem ümbardasime kõik... karjusele.

- Aga see Domna oli karjus?

Domna oli karjus, üheksa suve karjatas. Nainegi oli. Üheksa suve. Aga Johor ei tea mitu suve karjatas. Niimoodi.

- Aga mispärast ümbardatakse?

Aga, näed, metsloomade pärast, et metsloom ei puutuks, hunt, ta sellepärast ümbardas. Ikooniga.

- Ja, ja, ja hunt ei puutu?

Jah, et hunt ei puutuks, neid loomi.]

(L. P., Ladv, Leningradi oblast, 1981; RKM Mgn II)

Mõnevõrra erinev võib olukord olla siis, kui karjus on olnud oma pere liige, näiteks isa. Siis on täheldatav lapse pilk vanema teatavale erisusele mingis iseloomulikus situatsioonis (vrd ka varemtoodud näide), kuid olukorra lähem teadvustamine võib olla suhteliselt piiratud või ühekülgne ka siis.

On iseloomulik, et traditsioonilise jutustamise seisukohast torkavad enam silma naisinformandid, kellele suhtlussituatsioonid võõraga (uurijaga) samavõrd huvi pakuvad. Nii võib juhtuda, et informatsioon jääb soolises plaanis mõnevõrra ühekülgseks või kiputaksegi kogu kogukondlikku traditsioonilist kultuuri nägema naisekeskse või ainunaiselikuna (vrd Heikkinen 1994: 164-166). Nii võib kujunev pilt osutuda ühekülgseks või lausa vildakaks. See oht on olemas ka karjusemaagia käsitlemise puhul, kuivõrd tegemist on teemaga, kus on olulisel kohal kultuuriliselt konstrueeritud sugu. Võib olla kindel, et meesinformantide vaade erineb antud teemal naiste omast, sest 20. sajandi teisel poolel olid ühiskonna tugevama soo esindajad rahvausu teemade suhtes kas tõrjuval või lausa eitaval seisukohal. Pikaajaline kohaliku sovhoosi peainsener A. P. Nemža külast, kellega oleme sageli välitöödel vestelnud, vestles küll meeleldi majandielu ja selle likvideerimise teemadel, tutvustas ka oma perekonnalugu, kus sagedasti kordus kulakukstegemise teema enne sõda. Loomapidamise ja karjatamisega seotud maagiast rääkimast ta aga hoidus, sest ei 
pidanud seda kõneväärseks, kuigi ta pidi kahtlemata teadma, et ka nõukogude ühismajandite karjused viljelesid 20. sajandil selles piirkonnas traditsioonilist maagiat, mistõttu neid ka hinnati.

Sootuks oma seisukoht on nähtavasti karjusel, kes lähtub pigem talle kohustuslikust vaikimisdiskursusest. Ladvas elav, 27 aastat karjuseametit pidanud ja karjuste perekonnast võrsunud V. V. rõhutas 2010. aastal antud (paraku küll valdavalt venekeelses) intervjuus korduvalt, et karjuse asi oli hoida keel hammaste taga. Ühtlasi lausus ta kujundlikult, et karjuseks hakanu "sünnib uuesti". Mees, kes oma viimase piiramisriituse viis läbi 1993. aastal, kirjeldas ka (liigutustega ette näidates) metshaldja karistust - kes suruvat kokkuleppe suhtes eksinud karjuse kaelapidi mahakukkunud roosavarre alla ning murdvat niiviisi varrele peale surudes ohvri kaela. Loitsuteksti ütlemisest keeldus V. V. kategooriliselt, kuigi ta enam karjusena ei töötanud.

Karjusemaagia uurimisel saame seega kõnelda laias laastus kahest vastandlikust perspektiivist: kogukonna tavaliikme (harilikult naise) esitatud perspektiivist, milles karjus jääb tegelikult tabamatukspüüdmatuks, ning karjuse (rituaali läbiviija, maagilise vahemehe või saladuse hoidja) vaatevinklist. Üks väheseid otse karjuselt pärit tekste leidub ka M. Zaitseva ja M. Mulloneni vepsa tekstide kogumikus (1969: 228-232), milles (nais)karjus kirjeldab 1964. aastal ümbarduze tegemist, kus loitsu luges tema asemel rituaalis osalenud teadja:

Ümbärdeliiiń živataažed kaek. Kut ümb ärtas? Saba karvaažiid, da avadmed zamkamu da munan, da tohusut kandaažen. Sidomaa paikha nece ümb’ärtes: muna i tohusuti kaek. Panomaa kirffen ńecen, ülahaks jumalaažen śidomaa rehtho, a sid ńecen živatan ümb’ärdaamaa koumašti. Kirvez käzivardoo ülhäkspää teraa pidän. Astun jälghe, toeńe meź lugeb (mina en mahta_ka): “zvériišpää kaekiišpää, $i$ ken mas ujeleba ka śiišpää”... ümb’ärdamaa koomhe kerdha ńecen živataažen, śid rehton avaedamaa $i$ pästamaa necen živatan ühthe. Rahvast nikeda eba pästa śina. Ümb ärdaba kodiš, pöödos. Ken ümbärdeleb, ka obhodanandai sanub: "ala śiga laide, ala matikoite, ńimida pakostí ala, ka śilaa lehmaažed oloba družnas méecas $i$ tuloba kodhe".

[Piirasin kõik loomad. Kuidas piiratakse? Võtta karvad ja võtmed lukuga ja muna, ja küünlajupp. Seome räti sisse selle ümbarduze: muna ja küünal ja kõik. Paneme kirve, seome üles 
väravalaua külge ikooni, ja siis piirame need loomad kolm korda. Hoian kirvest teraga ülespidi. Astun järel, teine mees loeb (mina ju ei oska): "kõigi kiskjate eest, ja kes maas roomavad..." piirame kolm korda need loomad, siis avame värava ja laseme kogu karja kokku. Inimesi sinna ei lasta. Piiratakse kodus, väljal. Kes piirab, ümbarduze andja, ütleb: “ära seal sõima, ära vannu, midagi halba ära tee, siis sul on lehmad metsas koos ja tulevad koju."]

Karjuse ja tavainimese erinevate perspektiivide tagant kumab erinev religioosne kogemuslikkus ja sellele vastav kujutamislaad. Kasutades siin religioosse kogemuse käsitlemisel ja liigitamisel Harvey Whitehouse'i imagistic - doctrinal jaotusmudelit (2008: 41-44), on vastandlikkus ilmne. Esimesel juhul (imagistic) domineerib võimas isiklik (traumeeriv, ekstaatiline) kogemus, mis paneb aluse arenenud isiklikule, teadlikul reflektsioonil põhinevale teadmisele; aga ka religioossele innovatsioonile. Teisel juhul (doctrinal) on tegemist doktriinse õpetatuse ja rituaalse korduse mõjuga, milles isiklik kogemuslikkus nii suurt rolli ei mängi. Selline perspektiiv loob pigem süstematiseeritust, religioosset korda/ korrastatust. Karjusemaagia ja -rituaalid rahvausu osana kujutavad endast mängumaad, kus leidub ootuspäraselt ruumi mõlemale vaatele.

Kogukonna tavaliikme vaatenurgast on karjuse tegevus stereotüüpne, piiratud, sellisena kindlapiiriliselt visualiseeruv ja omamoodi tavaline. Päris kindlasti on karjuse tegevust jüripäeval (nagu ka muid kalendaarse kombestikuga seotud sündmusi) aasta-aastalt nähtud ja jälgitud, ise otseselt sündmuste keskmes asumata. See on loonud korrastava ja süstematiseeriva teadmise karjusest ja tema tegevusest, mis võib piirduda mõne lause või jutustusliku lõiguga. Sellisena ei tarvitse karjus oma tegevuses näida enama kui veidra marginaalina, ühiskonna äärealale tõrjutud ametimehena, kes lihtsalt peab oma kohust täitma vastavalt kogukonna tellimusele ja vajadustele. Kujutluspilt temast on moodustunud läbi korduste aastast aastasse, läbi pealtvaatajate silmade, kes pole kunagi üritanud või saanud asuda muule vaatepunktile. Sellise ühekülgse allikainfo korral võib rahvausku uurides kujuneda kergesti materjali vaesustav olukord. Uurija asub siin enesestmõistetavalt kogukonna tavaliikme positsioonile, milles lahjendatud religioosne kogemuslikkus paardub interpreteeriva terve mõistusega. Sellisest vaatenurgast sündivad kvaasiühiskonnateaduslikud arutluskäigud ei ole pahatihti kuigi asjakohased ega huvitavad. 
Kogemuslik, imaginistlik perspektiiv, mida karjusemaagia puhul esindaks loomulikult karjuse enda vaatepunkt, pakub seesolija erakordset nägemust, kujutades endast sama mündi teist külge. Kuivõrd karjus on mitmetel juhtudel võinud pidada läbirääkimisi teispoolsuse (metsa) esindajatega või on ta vähemalt viibinud teadjaga koos läbirääkimistel, võime ette kujutada sellega seonduvat ebatavalist pinget ja erilist kogemust üldse, mida ta üldjuhul ei ole pruukinud saada kellegagi otseselt jagada. Ühe Nemžast pärit kirjelduse kohaselt on metsas läbirääkimisi pidanud teadja kutse peale "maa seest välja kerkinud hallipäine olend, kasvades kohalolijate silme all metsast kõrgemaks" (Trifojev 2013: 60-61; vt ka kirjeldusi Guljajeva 1986: 179; Moroz 2001: 255-256).

Karjus on olnud suletud omaenda maagilisse teadmisse, mida ta on pidanud kandma kogu oma olemuse ja käitumisega. See on suurendanud ta rolliomast erandlikkust (ja eraklikkust). Näib, et üldjuhul pole karjusel olnud midagi peale hakata kogukonna arvamuste või ettekujutustega tema usundiliselt laetud tööst, see on tema seisukohalt olnud kõigest profaanne keelepeks või rumalus. Kogukonna-keskse ühtlustava perspektiivi asemel on iga karjuse puhul eraldi valitsenud kogemuslik ja rituaalne ainukordsus, mis tegelikkuses väljendub iga ümbarduz-rituaali kui lepingu individuaalsuses, selle punktide varieeruvuses isikuti, millele viitavad ka erinevad paikkondlikud kirjeldused.

Karjuse kombekohane suletus ja isoleeritus on genereerinud ja taastootnud tema suhtes kohustuslikke stereotüüpe, mida üksikasjades võivad sealsamas iseloomustada samuti vasturääkivused. Põhjavene kultuuriruumis laiemalt ei näi valitsevat ühest selgust sellest, kas karjus on pidanud olema füüsiliselt ebatavaline, muuks tööks mittekõlblik või hoopis vastupidiselt tugev ja otsekui äravalitu suhteks teispoolsega (Mišurinskaja 2000b: 59; ka Fišman 1986: 194-196). On ilmne, et karjuse määratlemisel domineerib füüsilise asemel hoopis kultuuriline stereotüüp. Karjus on pidanud olema kogukonna poolt irrutatu, kultuuri äärele tõrjutu, ning tema sellisena märgistamiseks või äratundmiseks on sobida võinud väga erinevad jooned.

J. Lotman ja B. Uspenski (1982) on käsitlenud sellist sotsiaal-psühholoogilist tüpaaži kui "oma võõrast" - rolli, mis samaaegselt tekitab võoristust ja austust, on igal juhul ühiskonnale/kogukonnale vajalik, samas distantsi hoidev, temaga samastuda mittetahtev. Sellised iseloomulikud jooned on äratuntavad ka karjuse juures põhjavene (sh vepsa) kultuuriruumis. Karjus ei ole seal üheplaaniline põlualune 


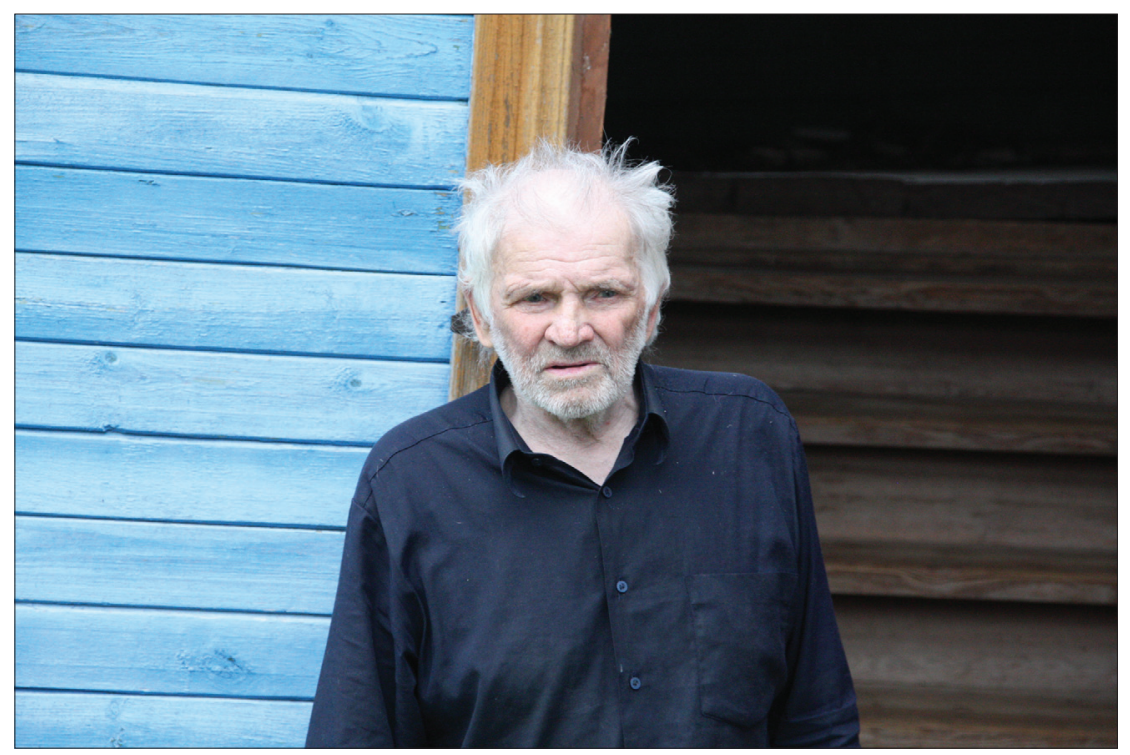

Foto 4. Eluaegne karjus Ladva külastust. Madis Arukase foto 2011.

või alavääristatu, nagu seda esineb näiteks lõuna pool (vrd ka Zelenin 1991: 87). Vastupidi: siin tunneb ja tajub karjus hästi oma rolli, selle kohustusi ja piire, teda on respekteeritud, ning see respekt pole olnud ühemõtteliselt positiivne või ülistav. Karjuse kui kultuuriliselt irrutatu vastuolulises kujus võib näha n-ö eelkultuurilisi jooni, mis ei allu lihtsustava (õhtumaise) hea-kurja vms dihhotoomiale. Ühes lõunavepsa muinasjutus esineb karjus vastanduses papiga, kelle loomi ta karjatama peab (vt Kettunen 1925: 41-43). Papiga konflikti sattudes paneb karjus maksma oma maagilised võimed pillimängu näol, millel on inimühiskonnale destruktiivne mõju - ta tantsitab nõrkemiseni nii loomi kui ka inimesi. Eelnevad näited viivad meid küsimuse juurde karjuse kui sellise kultuurilisest geneesist, sellest, millisest religioossest rollist ja kultuuritüübist võiks pärineda tema arhetüüp. See küsimus ei ole põhjavene kultuuriruumi kultuurilist ja etnogeneesilist mosaiiksust arvestades sugugi põhjendamatu või kohatu. 


\section{Piiramisrituaalile eelnevad tegevused}

Piiramisrituaalist (vps ümbarduz) oli ühes eelnevas keelenäites juba fragmentaarselt juttu. Kogukonna tavaliikmed on saanud karjuse rituaalset tegevust jälgida karja väljalaskmispäeval, milleks harilikult on olnud jüripäev, mõningatel juhtudel ja ilmastikust sõltuvalt ka mõni teine aeg, näiteks nigulapäeva paiku (vrd Moroz 2001: 233; Guljajeva 1986: 173-174; vepslastel Vinokurova 1988: 6, 14-19; 1994: 69-70, 73-75). Sel päeval on toimunud rituaalne karja piiramine (ümbarduz, obhod). Siiski on ka sellele eelnev aeg sisaldanud karjusele olulisi tegevusi seoses rituaali ettevalmistuse, selleks ja karjatamiseks vajalike esemete ja vahendite saamise, eelkõige aga maagilise lepingu sõlmimise ja selle tingimuste üle läbirääkimisega.

Maagilise lepingu sõlmimiseks metsaga on karjus pidanud läbirääkimisi pidama kas ise või on seda toimetanud temast teadjam isik - kogukonna teadja või mõni kogenum karjus (vrd Stepanov 2006: 257-258; Bobrov \& Fintšenko 1986: 155-157 jt). Siin võime juba näha rollilist jaotumist. Ilmsesti on leidunud nõidkarjuseid, kes on olnud võimelised kandma rituaali maagilist poolt ja karjusetööd täies ulatuses, olles üheaegselt nii tegevuses agentsust omavad subjektid kui ka mingis mõttes lepingu objektid. Siin avaldub kogu karjatamiskompleksi jaotumine dünaamiliseks ja staatiliseks pooleks, just karjuse seisukohast. Dünaamilisust võib näha jüripäeva ja piiramisrituaali eelses perioodis, milles karjus (või teadja tema eest) on läbirääkija, maagiliselt aktiivne pool partnersuhete sõlmimisel, piiriületaja, kes siseneb inimlikult poolelt metsa sfääri. Pärast tingimustes kokkuleppimist ja lepingu kinnitumist tuleb karjust käsitleda staatilise karakterina, kelle põhiülesanne on olnud kokkulepetest ja tabudest kinnipidamine, ja just sellega oma ülesande (ja kutsetöö) täitmine kogukonna ees.

Siinkohal tuleb märkida, et jutt käib just sellest ümbarduze liigist, milles teiseks lepingupooleks on animistlik metsasfäär eesotsas metshaldjaga. See on tähendanud ühiskarja andmist metsa meelevalda, metsa hoida. Metsas kui animistlikus sfääris on nähtud karja heaolu eest seisjat, mis kogukonna tavaliikmete silmis on kehastunud karjuse isikus. Mets on seega olnud ühteaegu nii karja ohustaja kui kaitse garantii, sealjuures on inimliku poole pealt vaadates olnud suurim vastutus just karjuse kanda, mis on taganud ka karjuse iseäraliku respekteerituse kogukonna silmis. Samas on karjusele langenud ka suurim pinge, alates lepingu sõlmimisest teispoolsega ning tabudest 
kinnipidamisega seejärel. Samas on selle pinge ja kohustuste väljapidamise korral olnud karjuse tegelik töövaev suhteliselt olematu - karja pole nii de jure kui de facto hoidnud mitte karjus, vaid animistlik mets või metshaldjas, kusjuures karjuse ülesanne on olnud vaid karja hommikune metsa juhtimine ning ta tagasitoomine või -kutsumine õhtul.

Selle nn metsiku leppe kõrval on eksisteerinud ka "jumaliku" leppe variant, mis on tähendanud, et tegeliku karja hoidjana on nähtud taevaseid jõude (vrd eriti Moroz 2001: 235-240; ka Durasov 1988: 103-104; 1989: 276; Fišman 1986: 193-194). Sel juhul pole toimunud lepingu sõlmimist metsaga, ehkki piiramisrituaal on läbi viidud samuti. Kristliku (st siin kristlusekesksema) rahvakultuuri seisukohalt on tegemist olnud ilmselt läbinähtavama toimemehhanismiga, igal juhul pole sõlmitud maagilist lepingut metsaga, mida venelaste seas on nimetatud ka "kohutavaks" (vn strašnõi, Moroz 2001: 238) või Tveri karjalastel "kuratlikuks" (Fišman 1986: 193). Sellise lepingu korral on karjuse töövaev olnud ilmsesti suurem, kuigi uskumuslikult on siingi tegemist maagiaga, kuivõrd karjatamisel on abiks olnud pühakud, kellele on adresseeritud ka vastavad loitsud. Mõistagi on meie ees usundiliselt ja ideoloogiliselt laadilt kaks täiesti erinevat karjatusviisi, vähemalt dualistliku maailmavaate seisukohalt. Partnersuhe kas metsa või jumalike jõududega viitab ilmselt erinevatele traditsiooniökoloogilistele uskumustüüpidele, ehk ka loodustingimuste ajaloolistele mõjudele ning erinevatele elatusviisidele. Kolmanda tüübina võiks välja tuua veel täiesti mehhaanilise karjatamise ilma otsese maagia ja eriteadmisteta, mida meie käsiteldavas läänemeresoome-põhjavene areaalis on vähem ette tulnud. Just viimases tüübis võib karjust pidada täiesti tähtsusetuks marginaaliks, kelle suhtes kogukonna tavaliikmetel on jagunud vaid põlgust. Sellisena on teda kirjeldatud ka slaavi traditsioonis üldisemalt (Zelenin 1991: 87; Moroz 2001: 249).

Rahvapärase jutustamise seisukohalt pole "metsiku" ja "jumaliku" karjatamise eristamine võinud esialgu (või üldse) mitte välja tulla. ${ }^{3}$ Võimalik, et inimesed pole otseselt teadnud karjuse maagilisest seljatagusest, partneritest ja vastavate maagiliste võtete arsenalist. Erilise ametimehe suhtes pole nad võinud ega saanudki sellist huvi üles näidata, jättes kokkuleppeliselt ja vaikimisi kõik professionaalsed eriteadmised karjuse enda teada sellest teadlikult distantseerudes. See omakorda on suurendanud ka karjuse kui rolli üldist anomaalsust. Kahe erineva karjatamisviisi erinevus tuleb jutustamises esile vaid üksikutes detailides. Paljud iseloomulikud ja värvikamad üksikasjad karjustest kõnelemisel näivad aga viitavat just "metsiku” lepinguga 
seotud karjatamisele, ehkki mitte täielikult. Nagu öeldud, on karjuste tegelikud ümbarduzed (nii lepingute kui rituaalidena) olnud alati individuaalsed ning üldistava astme on neile andnud justnimelt rahvasuu.

Jüripäeva eelses dünaamilises faasis (mida vepsa keeles on nimetatud ka veraz aig - Vinokurova 1988: 7; 1994: 70) on karjus viinud läbi toiminguid, mis on võinud hilisemal karjatusperioodil olla talle keelatud või võimatud. Just nüüd on ta valmistanud omale kirve- või noatööd eeldanud karjusekepi või -pasuna (hilisem puude-taimede raiumise keeld), samuti kogunud omapäi mööda lautu käies karjatatavate loomade karvu (Durasov 1989: 267), et neid hiljem kaitsemaagias kasutada. Juba selline, kõrvalisele otsekui lubamatu lautaminek viitab karjuse rolli erilisusele, eriti arvestades, et traditsioonilises ühiskonnas on laut olnud võõraste eest pigem suletud sfäär, mida on hallanud pererahvas (eeskätt perenaine) koostöös õuehaldjaga. Karjuse tungimises perenaise sfääri võib näha ka seksuaalset konnotatsiooni või intriigi - mille juurde tuleme tagasi ka hiljem.

Nagu juba öeldud, sisaldab karja väljalaskmisele eelnenud aeg endast piiriületust (või -rikkumist) võimaldavat perioodi, mil muuhulgas on metsast toodud ka sipelgapesi ning puistatud neid karjateele. Sipelgad ja sipelgapesad on analoogiamaagiliselt olnud seotud karja terviklikkuse, koospüsimise ja kokkuhoidmisega, mis kajastub ka vastavates loitsuvormelites. Teiseks on karja väljalaskmisel maagiliselt kasutatavateks abivahenditeks olnud urbepäeval kirikus või kabelis onnistuse saanud oksad (vrd Vinokurova 1994: 75; 1988: 18 jpt). Ehk saab siingi näha metsikusest pärit inimühiskonda transformeeritu näidet, mis nüüd vajalikku rakendust leiab.

"Metsiku" lepingu puhul on pidanud toimuma ka läbirääkimine maagilise lepingu tingimuste üle. Mõned teated sellest viitavad "tavapärasele" olukorrale metsas või piirialal, kus leiab aset sageli üleloomulike kogemustega seotud kohtumine karjuse (teadja) ja metshaldja vahel ning vastav läbirääkimine või isegi võitlus (vrd nt Fišman 1986: 196-197; Guljajeva 1986: 179). On iseloomulik, et neil puhkudel on karjus võinud kanda villaseid kindaid (ka Krinitšnaja 1986: 184). Folklooritekstides leiavad sellistel puhkudel metshaldja saabumisel aset koletud nähtused - suur tuul, puude paindumine (Salve 1995: 372) - mille suhtes inimliku poole esindaja peab üles näitama erakordset meelekindlust. Ühes 1916. aastal üles kirjutatud vene folklooritekstis on sarnast lepingusõlmimist muuhulgas kirjeldatud järgmisena: 
Karjus võtab metsiku ümbarduze (originaalis: otpusk)

(Tuttav karjus, kes enam ei karjatanud, rääkis:) Aga vot, räägib, missuguse ümbarduze ma võtsin. Vot, räägib, homme on vaja kari välja ajada - ma lähen metsa, kolm korda vilistan, panen sõrmed suhu. Vot, tuleb metsisand [---] Selline vennike tuleb. Nagu inimene, vanamees tuleb. Tervitame, teeme suitsu. Mina, - ütleb, - talle: "vot, mina olen karjus, kuidas seda teha, te annate ümbarduze, räägitakse, noh, mis sa selle eest võtad? Et sa mulle ümbarduze annaksid, et metsloom mul loomi ei puutuks ja inimesed, et loomad kaduma ei läheks?" Tema [metsisand] räägib: "Vot mis ma sult võtan: kõige parema lehma." Aga kuidas, - räägib [karjus], - ma kõige parema lehma? - Aga vot, kui välja ajad, hakkad neile ringi ümber tegema, löö teda piitsaga. Tema, - räägib, - jookseb ära ja rohkem tagasi ei tule.

Vot, - räägib [karjus], - karjatamise eest võttis ta mult lehma. - Aga edasi, ja, - räägib (metsisand), - sulle tuuakse lõunat, seal midagi head tuuakse, - teatud heinakuhja pane. Siis ma sulle niimoodi, kui täidad mu käsud, aja ainult [kari] välja siia maatükile, aga ülejäänu (st sealt edasi) karjatan mina. Aga [karja koju] ajama ära tule, võta siit, siin on kõik.

Kõik sai(?), sest et, noh, ta selline kindlakäeline [karjus] oli. Räägib, - nagu kokku lepime: vot, kui ütleb, et vot perenaine, et tuleks alati riides välja, rätikuga, aga mitte nagu ei tea mis. Vot nii. Nii nad tegid. Ja tema kogu suve karjatab, ja temal, mõtle, räägitakse, käivad hundid karjas ja ei puutu lehmi. Ise jutustas: "Hundid tulevad, käivad, - räägib, - karjas ja ei puutu lehmi." Aga kui lehm nagu maha jäi, nii ta ainult läheb sinna karjatuskohta, kõik rääkisid, läheb karjatuskohta, kolm sõrme paneb suhu, vilistab ja istub, ja lehm tuleb.

[Kas ümbarduzel sõnad olid?] - Kuidas muidu, ikka olid, no sõnu [ei öelnud].

(Moroz 2001: 255-256)

Karjused, kes ise maagiliseks lepingusõlmimiseks ühel või teisel põhjusel võimelised pole olnud, on pidanud kasutama teadja abi. Võib arvata, et sel juhul on lepingu metsaga teinud teadja, kelle "töökohuste" hulka metsaga sidemes olemine (näiteks kadunud loomade-inimeste otsimisel) nagunii kuulub. Arvatavalt on karjus seeläbi saanud ka 
oma konkreetse lepingulise kohustuste-keeldude "komplekti" antud karjatamishooajaks, millest kinni pidada. Sõnaühend "ümbarduzt võtma" viitab selle saamisele kelleltki (metshaldjalt; teadjalt), samas justnagu ka mingile karjuse-poolsele aktiivsusele või agentsusele selles tegevuses. Karjustel, kel endal pole teadjakompetentsi olnud, on jüripäeva eel olnud teadjate juurde sihipäraselt asja, kuivõrd karjust on hinnatud just tema maagilise kompetentsi tõttu, mis on aga olnud ka mingi tasu eest omandatav. Ümbarduze all saame antud juhul mõista niisiis mingit maagilist vormelit, mis on kas saadud-omandatud äraõppimise teel või siis eksisteerib esemelisel kujul - loetuna teadja poolt millelegi (vrd ka Bobrov \& Fintšenko 1986: 154).

Ilmselt ennekõike seoses "jumaliku” ümbarduzega on karjus võinud vallata või omandada ümbarduzt ka kirjalikul kujul. Jutt käib siin pikematest juhendilaadsetest loitsukogumikest, mis on võinud endast kujutada otsekui väikseid käsikirjalisi raamatukesi. Selliseid üleskirjutusi on võidud üksteiselt osta, ning nad on käibinud kinnitustena karjuse kompetentsist ja maagilisest potentsist. Sellised kirjalikud obhodid on levinud ennekõike just põhjavene piirkondades ning mõningad neist on jõudnud ka uurijate kätte (vt eriti Bobrov \& Fintšenko 1986; Morozova 2001). Paljuski viitavad nad (ka stilistiliselt) kristlikule-kirikulähedasele päritolule (Fedosova 2010: 132 jj), mis annab alust siduda neid ennekõike "jumalike" lepingutega. Nende geneesipiirkonnana on oletatud vanausuliste asuala (Bobrov \& Fintšenko 1986: 164), kus kirjaoskus on olnud kõrgemal tasemel. Kuivõrd ajalooliselt on tegemist olnud pigem venekeelsete kirjalike tekstidega, ${ }^{4}$ on küsitav, kuivõrd nad said kasutuses olla vepslaste hulgas, kelle vene keele oskus oli 20. sajandini pigem kesine. Ladva külast pärit eelmainitud karjus V. V. ütles, et "tekst oli kirjas vene keeles, loeti aga vepsa keeles". Siinkohal tuleb arvesse võtta, et kirjalik obhod on võinud käibida ka artefaktina - piisanud on üksi tema olemasolust, või on selle rituaalis ette lugenud mõni kirjaoskaja. Suulise kultuuri suhe kirjalikkusega on nagunii spetsiifiline, mille juurde veel tagasi tuleme.

Näeme seega, et nagu maagias kohane, on ka karjuse hooajaks ettevalmistavate (dünaamiliste faasi) toimetuste puhul võimalik igasugune asendamine. Oluline pole olnud mitte konkreetse isiku otsene agentsus, vaid see, et mingid toimingud on tema nimel õigeaegselt ära tehtud, misjärel karjus on saanud oma hooajalist põhikohust täitma asuda. Võib arvata, et kõik see on taas vaid suurendanud karjuse kui rolli mõistatuslikkust tavainimese silmis. 


\section{Piiramisrituaal}

Piiramist (vps ümbarduz, vn obhod, otpusk, spusk jm, karj kierokšet, kierros) võib käsitleda kui omalaadset universaalset võtet millegi kaitse alla saamiseks / ohuallikast eraldamiseks seda ringikujuliselt ümber piirates. Maagiline ring võib rahvakultuuris esineda ka muudel riitustel, eriti kalendritähtpäevadel. Sarnast võib leida ka kõrgreligioonides (näiteks ristikäik ümber kiriku) ning loomulikult kerkibki siin küsimus karja piiramise rituaali konkreetsest algupärast - kas selles võib olla midagi kristlikust kombestikust tulenevalt jäljenduslikku? Ilmselt on selles siiski piisavalt universaalset (püha kui algselt struktureerumatu situatsioon, mille käigus toimub uuestipiiritlemine, - korrastamine vrd Anttonen 1992: 2519).

Jüripäevase karja väljalaskmise kombestikuski võime jälgida tegelikult karja piiramist rohkem kui ühe korra. On tavaline, et enne, kui loomad kodusest majapidamisest ühiskarja (karjuse käsutusse) lastakse, viiakse esimene piiramine läbi kodus, laudas või hoovis. Selle viib enamasti läbi perenaine, mis muuhulgas iseloomustab ka tema maagilist suhet oma loomadega. Just erilisem suhe perenaise ja ta lehma(de) vahel ilmneb ka alloleva näiteteksti lõpus:

Paimen, ka paimen pästab, živataized pästab, pouktasse paimnhedab, pästab živataized meca, tordusen tegeb, tropkeižen$d a$ (imiteerib häält), en tä, kut hän tordub se, en mahta mińä torde.. Lehmeižed meca mändas, sigä pa-ajab, veras tedab ka.., ei mit tuldas ičehil lehmižed.. en tä mińhe sigäs.. lõüdüdas-ka, mina sid en tedä, miń lehmäd tuldas iče.. Meil so... kogonaine lehm kadoida ühtel vodol, paimhe pästi meda Järvešsa, en tä, mellel tä meń kunassa lehmeine, em voi doda luda enambad, mugai kons om män lehmad elmei kezan. Živatad pästas jälge jürgi, jälge miklanpä-dä, jälge miklanpät pästas, toižol po miklanpäs pästas, prasnik om miklanpei, tögä prasnuda. Pästa živataižed, jumalaižel ümbärdas edol, jumalaižes alliči pästas, a ńuguda i pästkoi jumaližes alliči-ka, edu ol jumalai.. jumalaižen ottase, lehman pästasse, kaiki živatoid pästas jumalaiženke, a nugud i päžttkoi-že muga-ka, en tedä kut edu.., edu živataižein jumalaiženke pästliba, da nece barbeiženke-da (...)

- A isand, nece isand..

$E i$, emäk pästab, se emäk pästab lehmeižen, ižand heboižen kärdhä-da edo pašme ajab, mec.. kesämad tegessa-ga pašib, 
libad mändob-da.., hernes semendab-da, konsgi mida ka pašme ajeb, hän o heboine kädhe, hebo kädhes, ižandol, a emägol lehm.

[Karjus, (kui) karja välja laseb, metsa laseb, teeb pasuna, karjateel (puhub), ei tea, kuidas ta puhub, mina puhuda ei oska... Lehmad lähevad metsa, ajab (nad) sinna, võõras (karjus) teab, et... ei tule (oma) lehmadega.., ei tea mina seal... (kas) leitakse ka, mina seda ei tea, minu lehmad tulevad ise... Meil soos... ühel aastal kadus lehm täitsa ära, karjus lasi välja Järvedes, ei tea, kuhu (mis jälgedele?) ta läks, ei suutnud teda leida enam [---]. Loomad lastakse välja pärast jüripäeva, nigulapäeva järel, pärast nigulapäeva, nigulapäeval on praasnik, siin peetakse. Loomad lastakse välja, ikooniga piiratakse alguses, ikooni alt lastakse läbi, aga nüüd ei lasta ikooni alt läbi, enne oli... võeti ikoon, lasti lehmad, kõik loomad lasti ikooniga, aga nüüd ei lasta niimoodi, ei tea, kuidas enne... enne lasti ikooniga ja nende vitstega (...)

- Kas peremees...

$\mathrm{Ei}$, perenaine laseb, perenaine laseb lehmad, peremees hobused...]

(D. N., Viĺhal, Leningradi oblast, 1982; RKM Mgn II)

Kui karjuse poolt hiljem läbi viidav ümbarduz tegeleb kogukonna ja metsa vahelise piiri problemaatika ning karja kaitsega metsloomade/ metsa stiihia eest, siis perenaise poolt läbiviidav kodune ümbarduz markeerib kodu ja koduvälise sfääri piirisuhet. Maagilises mõttes leiab see aset õuehaldja pilgu all ning muuhulgas küllap ka tema "nõudmisel", mets ja selle animistlik esindaja siin asjasse ei puutu, küll aga püha Jüri (vrd Vinokurova 1994: 70) ${ }^{5}$.

Vepslaste karja väljalaskmise rituaale on iseäranis uurinud Irina Vinokurova, kes on välja toonud ka siin esile tulevaid regionaalseid eripärasid. Perenaine on piiranud loomi laudas, kasutades selleks tuulamissõela pandud maagilisi esemeid - ikooni, mõnda terariista, põlevat küünalt, rituaalset leiba, karjakella, muna, ka muud. Käes on võinud olla ka kirves, samuti suitsevad söed. Siis on perenaine lasknud loomad laudast välja, markeerides künnise maagilise esemega - asetades läve alla noa või kirve (metall) või omapunutud vöö (Vinokurova 1988: 7-10; 1994: 70-71; Durasov 1989: 269 jj; Stepanov 2006: 255-256 jpt). Loomad on läinud läbi ka ikooni alt, mis on kinnitatud ukse ko- 
hale. Kodusel ümbarduzel on kasutatud ka süsi või suunatud loomi läbi lõkkesuitsu, lõunavepsas on pruugitud kivikesi, mida on üksnes vepslastel tarvitatud ka ennustamisel ja otsimisel.

Väärib tähelepanu, et juhtudel, kui perenaine on kevadel saanud käo poolt "petetud", st maagiliselt ära tehtud, kuuldes ootamatult käo kukkumist, pole ta ümbarduzt teha saanud ja seda on pidanud tegema keegi teine (Vinokurova 1994: 74). Võime arvata, et see pole viidanud mitte üksnes inimese rituaalsele ebapuhtusele, vaid tema otsesele seotusele teispoolsuse/metsaga, mida selles rituaali etapis olla ei tohi, kuna (eriti V. Turneri rituaaliteooriat silmas pidades) tegemist on alles irrutamisega koduses miljöös. Perenaise puhul on karja väljalaskmisel (nii jüripäeval kui ka igal hommikul hiljem) olnud tähtis tema "kultuuriline" markeeritus kombekohase riietusega. Väljalaskmisel pole perenaine kindlasti tohtinud olla katmata peaga või paljajalu, seda on muuhulgas jälginud ka karjus.

Kapša ja Ojati jõgikonna vepslastel, samuti lõunavepslastel on piiramisrituaal kodus haaranud endasse kogu majapidamise ja selle liikmed, toimudes ümber hoonete koos vastava loitsuga. ${ }^{6}$ Kui mujal on rituaali läbiviimisel domineerinud naispool (perenaine), siis Lõuna-Vepsa asualal on koduses piiramisrituaalis olnud juhtiv koht peremehel, seal on jüripäevaga seoses olnud säilinud laiemalt esivanemate kultusega seotud toiminguid, mis on vististi eeldanud meespoole juhtivat kohta. Irina Vinokurova on siin oletanud üldisemat soomeugri rahvastele omast kevadist esivanematekultust, mis lõunavepslastel on seotud ka karja väljalaskmisega (Vinokurova 1988: 14; 1994: 73).

Väljalaskmisrituaali teise etapi on Vinokurova lokaliseerinud teekonnale kodustest majapidamistest küla servale, kus kari on antud karjuse valdusse. Paljudes põhjavene piirkondades on see etapp võinud muuhulgas sisaldada ka loomade ajamist kabeli juurde ja nende õnnistamist vaimuliku poolt. Perenaised ajasid oma loomad mööda karjateed külast välja metsaserva, kasutades selleks muuhulgas urbenädala oksi, mis hiljem anti kas karjusele või hävitati muul moel rituaalselt.

- A bibričüd? Bibričüd andabad paimenele?

Birbnicad? Andoiba. Birbnicad andlimi.

- Emäg andab?

Emäg. Nu-ka birbnicäižen andab, ka paimen kogohoda.., en teä kuna hän birbhe... paimen ned uberheb, birbicad, em-i mińä. - A miń täht nened bibričüd andabad? 
Birbnicaižed? Eń tä. Miž što živataine sohranno käumiž. Metzas dveŕdi täht.

- A mižpei nened otavad nenüd bibričüd?

A birbnicaižed ot́limi penzaspei, nüdega. A muité pagastad oliba. Edu pagastas slušbad oliba, ka pagastaha todaz birbnicoid birbnicpühanpean. Edehko eät peti pühanpean. Pagastaha todaz väiböžed vicižed pö̈̈dän, no $i$ antaz birbniceižen tohusuden.

- A ken andab?

Pap. Eń t'ä, pap śigä.., storož vei.., eń mužda, ken andoile.

[- Aga urbepüha oksad? Kas neid antakse karjusele?

Urbepüha oksad? Anti. Oksi andsime.

- Perenaine annab?

Perenaine. Annab oksad, karjus kogub kokku..., ei tea, kuhu ta oksad... karjus paneb need, oksad, ei tea mina.

- Aga mispärast neid oksi antakse?

Oksi? Ei tea. Et loom kaitstud oleks. Metsas kiskjate pärast.

- Aga kust need oksad võetakse?

Urbepüha oksad võtsime põõsast, nüüdsel ajal. Aga muidu olid kirikud. Enne olid kirikus teenistused, kirikusse tuuakse oksi urbepühapäeval. Enne peeti väga urbepühapäeva. Kirikusse tuuakse vitsad põllult(?), ja antakse oksad küünalde eest(??)

- Aga kes annab?

Papp. Ei tea, papp või kirikuteenija..., ei mäleta, kes andis.]

(F. M., Ladv, Leningradi oblast, 1981; RKM Mgn II)

Loomadele - nii omadele kui võõrastele - jagati koduses ümbarduzes kasutusel olnud leiba (ristliib). Nagu sipelgatega seotud uskumus, pidi ka see ühendama ja siduma loomi ühte karja, et nad ei jookseks laiali ja säiliksid (koos). Karjusele on antud muna, ta taskusse on proovitud poetada münte (vrd nt Lonin 2000: 34). Seda rituaalietappi võib seostada ka üleminekuga kahe mõttelise ruumi/staatuse vahel, rituaali liminaalse faasiga (vrd van Gennep 1960), mil kodu, perenaise või õuehaldjaga seotud eri perede loomad on muudetud metsas viibivaks, metshaldja valitsusalas asuvaks jagamatuks ühiskarjaks karjuse vastutusel.

Karja saatmine kodunt metsaservale karjuse kätte on olnud aeg, mille jooksul pereinimesed on saanud (viimast korda?) omalt poolt mõjutada ka algava hooaja piimasaaki. Näib, et kuigi suurem osa sellega seotud maagiast on taas olnud karjuse hallata, on lüpsiõnne 
mõjutada saanud ka naised, heites näiteks karja saatmisel kasutatud õnnistatud oksad jõkke (vette). Üldiselt on usutud, et maagiaesemete seotus veega (nende heitmine või peitmine sinna) suurendab piimasaaki. Parema piimasaagi nimel on vette võidud jätta ka paberile kirjutatud ümbarduze tekst:

Paimen homesuu barabańib, živataižen pästab da päivas mécha ii_mäne, mäneb ehtkoižuu toĺko. hänou spuskaine lugesoi ükś remnile. Ŕemńiižen pidab v'üu. Živatan pästab ka remńińn välĺlendab, a živatan kogodaškab, remńiižen kinǵitab. Živataine gö kaik hänolo kogoho da lähemba kodit' kaik kogodasoki. A kudamban spuskan panod, bumagan-so, védho ka śüu kezau lehmad oma maidokah'embad. A kudambon kopab murazmätho ka śüu kezau lehmad maidon kadotadas, vähemban äjad anttas. Nu ka ńinga paimeta lehmad oma kebnembad i hän nadeiše, miše ńi mitt́e zver ii ńäge hänon živatad. Astub zveŕ päliči hänon stadas, nu ka zverille, hot kondi, hot' händikaz, nä̈gutoiš hänolo živat kandod da kived. Proidub hän päliči - kandod da kived, hän kosketa hiit ii, a paimen nadeiše, śikš i elab kaik päivad kodiš. a spuskata om paimeta pahoiń löumaiń.

[Karjus lööb hommikul trummilauda, laseb loomad metsa, aga ise päevaks metsa ei lähe, läheb õhtul alles. Üks spusk on tal rihmale loetud. Rihm on tal vööle kinnitatud. Kui loomad välja laseb, siis laseb ka rihma järele, aga kui loomad kokku kogub, siis pingutab rihma. Loomad kõik tal kogunevadki kodu lähemale. Aga kui spuski paned, paberi, vette, siis sel suvel annavad lehmad rohkem piima. Aga kui kaevab sipelgapessa, siis sel suvel jääb lehmadel piima vähemaks, annavad vähem. Noh, niimoodi on kergem karjatada lehmi ja ta loodab, et ükski metsloom tema loomi ei näe. Läheb metsloom läbi ta karja, ja metsloomale, olgu ta karu või hunt, näivad loomad kui kännud ja kivid. Läheb läbi - kännud ja kivid, ta ei puutu neid, aga karjus loodab, seepärast on kõik päevad kodus. Aga ilma spuskita on karjatada päris raske.]

(Zaitseva \& Mullonen 1969: 149-150.)

Kodusele ümbarduzele ja loomade juhtimisele külast välja on kolmandana järgnenud karjuse poolt läbiviidav ümbarduz. See on üldjuhul toimunud küla ääres, metsa piiril, kuhu on võidud ehitada ka spet- 
siaalne aedik. Aediku puudumisel on piiramine võinud teoks saada ka muul selleks sobival lagendikul külast väljas. Küla loomad on nüüd juba üksnes karjuse käes, teistele on jäänud rituaali eemalt jälgimine, mida on ka tehtud. Mõistetavatel põhjustel on just see olukord kõige rikkalikum karjuse tegevust puudutavate folklooritekstide temaatiline allikas - karjus piiramisrituaali läbi viimas. Karjus on olnud siin autonoomne peategelane, rituaalispetsialist, kelle tegevusse piiratud ruumis teised sekkuda saanud pole. Erandiks on siin võinud olla vaid olukord, kui karjuse eest on rituaali läbi viinud keegi teadjam või oskajam - teadja, vanem karjus, kasvõi naissoost isik (vrd nt Stepanov 2006: 257 jt, ka siin varem esitatud näitetekst), kel on olnud vastavad teadmised. Võib öelda, et neil juhtudel on karjusel olnud läbinisti staatiline roll lepingust kinnipidajana karjatushooaja jooksul.

Karjuse poolt läbiviidava piiramisriituse struktuur on olnud põhijoontes seesama, mis varemkirjeldatud kodusel ümbarduzel. Erinevus on ennekõike selles, et kui kodus on piiratud vaid oma loomi valdavalt laudas ja kõrvaliste nägemata, siis nüüd on see toimunud lahtise taeva all kõigi silme all. Harilikult on karjus teinud kolm ringi ümber karja (tavaliselt päripäeva), hoides käes sõela, milles on varieeruvalt võinud olla juba varem nimetatud maagilised abiesemed. Ühe atribuudina on karjusel käes või vöö vahel olnud kirves. Samas on karjus ümbarduzel kasutanud ka vahendeid, mida kodused rituaalid eriti tundnud pole. Silmapaistvalt huvitav on asjaolu, et maagiliste abiesemete seas on mõnede teadete kohaselt võinud olla ka vöö vahele riputatud haug (Bobrov \& Fintšenko 1986: 158; Moroz 2001: 233). Soovi korral võiksime siin näha seoseid šamanistliku, abivaimudega seotud pärandiga. On tõsi, et haug on rahvausus laiemalt tuntud kui veevalla valitseja. Karja kaitseloitsudes pannakse haug alla neelama võtit, millega kari on rituaali käigus sümboolselt ohtude eest "lukustatud". Šimǵäŕe vepslastel on haug olnud jüripäevasöögiks (Vinokurova 1988: 17; 1994: 74 ), samuti on selle piirkonna vepslased kasutanud haugi hambaid ohvriannina metshaldjale (Vinokurova 2006: 211).

Loomi on võidud ajada läbi lõkkesuitsu, kasutatud on ka hõbedat (hõbeeset), samuti on vepsa traditsioonist teada, et üheks karjuse kasutatavaks atribuudiks on piiramisel olnud ka ülesjuuritud noor kuusk. Varem, jüripäeva eel lautadest kogutud loomakarvad on karjus võinud koguda vahast palli, mis on sellisena võinud olla ka üks keskne maagiline objekt, millele on loetud ka ümbarduz-loits. Loitsu objektiks ning kaitsemaagia kandjaks on võinud olla ka lukk, mille pooled on rituaali alguses olnud eraldi (lukk lahti), lõpuks on see aga 
suletud. Tasub mainimist, et mõnede teadete kohaselt on maagiaeseme osiseks ümbarduze tegemisel olnud ka haualt toodud muld. Sellised maagiaga laetud ja lepingut kandvad vahendid on karjatushooajaks peidetud vaid karjusele teadaolevasse kohta.

Mistahes maagiaese, millesse on maagiline leping rituaalis või selle eel inkorporeeritud, millele on loetud vastav loits - kas mõni sümboolne ese (lukk, vahapall karvadega, karvakakk), karjuse signaalriist (pasun, trumm, piits) või muu vahend (karjusekepp, rihm, vm) -, üldjuhul on tulnud see kas karjatushooaja lõpul või vahendi "eluaja” lõppemisel hävitada, enamasti põletada. Hooaja lõpp on tähendanud sõlmitud lepingu lõppemist, mistõttu on tulnud vahepeal peidetud esemed uuesti peidust välja tuua ja "avada". Loitsudega varustatud muid vahendeid, mis muidu on nagunii võinud olla vaid karjuse kasutuses, ei ole sellistena kunagi võinud kasutada argises inimelus.

\section{Maagia semantika, terviklikkus ja selle rikutavus}

Piiramismaagia osistest võib esiteks järeldada, et kaasata on püütud erinevaid kõikvõimalikku päritolu vägesid/sfääre - tuld, metalli, surma-, metsa-, inimkultuurset. See viitaks nagu maagilisele kumulatiivsusele, soovile kindlustada karja "frontaalselt", võttes kasutusele kõikvõimalikku abi. Teine seletus võiks vihjata enam struktureeritud lähenemisele, kus maagias on esikohal olnud metsa ja ktoonilise teispoolsusega seotud elemendid (muld, puit, haug jms). Kuivõrd tegemist on ennekõike individuaalse lepinguga, on selle elementide süsteem võinud igal üksikjuhul olla erinev. Suurt rolli on võinud mängida ka asjaolu, kas tegemist on olnud "jumaliku" või "hirmsa, metsiku" ümbarduzega.

Universaalne näib aga olevat püüdlus sulgevale-varjavale semantikale nii tegevustes, sümboolikas kui ka loitsutekstides. Kari on pidanud läbi hooaja püsima koos, ühtse tervikuna. Seda keskset eeldust on kindlustatud maagiliselt, sidudes loomakarvu ühtsesse vahapalli, sulgedes lukku, samastades loomakarja sipelgapesa kokkuhoidmisega, vaigistava toimega on võinud olla ka hauamuld. Need maagilist lepingut kandnud ja rituaalis kesksel kohal olnud esemed on seejärel karjatushooajaks peidetud - uputatud vette, pandud sipelgapessa, karjusepasunasse, ka ikooninurka, karjuse enda riietesse jm (Moroz 2001: 234, 236-237; Krinitšnaja 1986: 185-186 jpt). Varjamine 
on taganud sõlmitud kokkuleppe rikkumatuse, eelkõige jälgides, et kõrvalistel inimestel ei oleks sellega mingit (füüsilist) kokkupuudet, mis automaatselt lõpetanuks maagilise lepingu kehtivuse ja toonuks kaasa karja kao. Et lapsed ei satuks kogemata näiteks sipelgapessa peidetud lepingut kandva maagiaeseme peale, on neid keelatud metsas sipelgapesi lõhkumast.

Teiselt poolt ei ole ka inimühiskond tohtinud ümbarduzrituaalist läbi käinud ja sellega metsa suhtes kokku "pitseeritud" karja lahutada, selle peade koosseisu muuta või rikkuda. Keelatud on olnud karjatusperioodil loomi välja müüa või tappa, samuti lisada - see oleks mõjunud hävitavalt kogu karjale (Zelenin 1991: 87-88; Moroz 2001: 234; Štšepanskaja 1986: 165-166 jt). Kaitstud ei ole olnud niisiis loomad ükshaaval (kuigi seda on pereti taotlenud iga perenaise poolt laudas tehtud ümbarduz jüripäeval), vaid üksnes karjas koos, tervikuna.

Teine keskne kujutelm, mis maagias kajastub, on karja varjatuks või nähtamatuks muutmine (Durasov 1989: 271-271; Moroz 2001: 246 jpt). Loitsutekstides lastakse karja ümber kasvada raudne sein, millest metsloomad üle ja karjale ligi ei saa (nt Bobrov \& Fintšenko 1986: 141; Vinokurova 1988: 8). Kariloomi on "muudetud" metsloomadele nähtamatuteks - kivideks-põõsasteks. Juttudes on karu võinud karja juurest lähedalt mööduda, sellest isegi läbi minna, ilma et loomad talle nähtavad oleksid olnud. Ilmselt on koduloomadele sama nähtamatud olnud ka metsaelukad. Selline justnagu paralleelmaailmade toimimine tingimusel, et lepingut ei rikuta, on karjatamisel olnud ideaal, millest on küllap teadnud vaid lepingu sõlmijad ise - metshaldjas ja karjus või teadja. Karja nähtamatuse kõrval on usutud siiski ka seda, et karja on metsas kogu aeg ümbritsenud animistlikud metsaolendid, kes seda (karjuse asemel) hoidnud on. Mõnel harval juhul on neid ka karja ümbruses nähtud.

Dünaamiline periood jüripäeva piiramisrituaali eel on karjusel võimaldanud nii maagilist tingimist kui ka tulevase partneri sfääri kuuluva füüsilist rikkumist-vigastamist, mis hiljem on olnud tabuline ja võimatu. Sel ajal on ta saanud muretseda rituaaliks vajalikud looduslikku päritolu tarbed - näiteks puine karjusekepp, vahest ka juuritud kuusk keskvepslastel (vrd Vinokurova 1988: 23; 1994: 75) (hiljem on puidu raiumine-lõikamine olnud mõeldamatu). Pärast rituaali ei ole karjus (sageli) tohtinud ka metsas maapinnal lõket teha. Rituaalis kasutusel olnud terariistad on samuti olnud hiljem tabulised, et neid kasutades kedagi või midagi vigastavat juhtuda ei saa. 
Sama on kehtinud ka suhtes loomadega, kes rituaali järel on otsekui "metsa omad" - karjus ei ole tohtinud neid lüüa ega nende peale häält tõsta. Pikka piitsa on karjus võinud viibutada vaid heli tekitamiseks loomade liikuma ajamisel. Õieti ongi ta andnud vaid loomadele metsamineku või kojutuleku signaale, kasutades selleks piitsa, pasunat või kuuselauast trummi - millele on võinud olla loetud vastavad loitsud, st tegemist on olnud samuti maagia, mitte lihtsa sundimisega. Samamoodi on toiminud ka karjusekepp või rihm, millele on loetud loits - keppi maha lüües või rihma pingutades on sunnitud kari paigal seisma või kokku kogunema ja vastupidi:

Paimen homenso libub, ne akad libutas, lehmad upravdas, lipsas, da jotas, söotas, kartohkoižed antas.., paimen libub $i$ soitüiže soitab - tul-lul-lul-lul-luu - eras $i$ kule, a eras kuližtab-ka upraiža, a vo, eras $i$ kule, a hän vo-toĺko teren annussa-tullul-lul-lul-luu - ninga. He kaik libuba, upravissa i lehmaižid.. paimen pästäb, soitab ninguine torvudhese, tordab, lävän.. tanhan avaitas, lehmaižen otab, dorogal oigendab paimen, töižö hosjaika po-mugažno lehmaižen otab, dorogal oigendab, kaiken derunan proidib nece paimen. Nu i lehmaižeid sleba provadlenneb, tolko iks paimen otli lehmaižed, meca pi(i)kseb. [---] No lehmaižed kaik setluessa, kaik setlassa ninga-ni. Važaized i lambhaižed i lehmaižed i kaik. Pabetkoiutžeb, ehtjo tegeža, nece otab noraižen ni.. vehuden kingitab ninga vähäižö-lehmaižed kaik kogoiže, kogoiže, kogoiže, i med dorogalle, i kodhe kaikid $i$ tob. Kodhe tuldaz. Kaik saobtab aihta, upraviseb, i magatha pannessa kaik spakoino.

[Karjus tõuseb hommikul, perenaised tõusevad, lehmad talitavad, lüpsavad, joodavad, söödavad, kartulit annavad..., karjus tõuseb üles ja puhub pasunat - tul-lul-lul-lul-luu - mõni ei kuule, aga mõni kuuleb ja talitab, aga mõni ei kuule, aga tema vot - küla otsas (?) - tul-lul-lul-lul-luu - niimoodi. Need kõik tõusevad, talitavad lehmad... karjus laseb välja, mängib sellist pasunat, puhub, laudauksed avatakse, võtab lehmad, juhib välja tänavale, karjus, teise perenaise käest samamoodi võtab lehmad, juhib välja tänavale, kogu küla käib läbi, see karjus. No ja lehmade järel käib, ainult karjus üksi läks lehmadega metsa [---] No lehmad on kõik koos, kõik on koos niimoodi. Vasikad ja lambad ja lehmad ja kõik. Lõunatab, õhtu tulles võtab nööri... vöö 
tõmbab koomale väheke - lehmad kõik kogunevad, kogunevad, kogunevad, ja lähevad teele ja koju kõik toob. Tullakse koju. Kõik pannakse kinni, talitatakse ja minnakse magama rahulikult.]

(A. K., Korvoiĺ, Leningradi oblast, 1975; RKM Mgn II)

Loomade löömine-sõitlemine on tähendanud kokkukuulumistabu rikkumist. Löödud loom on vastavalt ettekujutusele läinud metsale, st saanud murtud või läinud metsa kaduma. Ka loomakarvade kogumine (s.o looma füüsilise terviklikkuse rikkumine) on ootuspäraselt olnud võimalik üksnes enne ümbarduzt, pärast seda on kõik pidanud säilima põhimõtteliselt puutumatuna.

Küll on aga karjus tohtinud perenaist piitsaga lüüa, kui see on tema ette ilmunud näiteks katmata pea või paljaste jalgadega (nt Štšepanskaja 1986: 169; Moroz 2001: 244). Karjus pole niisiis passiivselt hoidnud üksnes metsikuse terviklikkust, vaid omamoodi ka inimkultuuri moraalsust, mille abil on markeerunud inimliku ja loodusliku erisus ja piir. Ta on pidanud kontrollima, et inimlikus käitumises ei ilmneks "metsikusele" viitavaid hälbeid ja segunemist, saamata samas ise tavamõttes inimlikule (argisele) väga ligidale minna.

Maagilise lepingu kõige kindlam tagatis karjuse poolt on olnud staatilisus, letargilisus, äraolevus, ehk isegi autistlikkus, mis on aidanud ära hoida soovimatud käitumuslikud eksimused. On ootuspärane, et kui lepingu ja rituaali tegemise eest on vastutanud keegi teine (teadja), siis ongi edasiseks tööks (lepingu kandjaks) sobinud kõige paremini autistlike joontega, tavamõttes ebanormaalne inimene - roll -, kellena karjust tihti ka nähtud on või keda on karjuseks pandud. Siin võib võrdluseks tuua kümneid muinasjutumotiive karja saadetud rumalast tegelasest. Rituaalieelses dünaamilises faasis on karjus olnud aga tingija, metsa- ja lautatungija, rikkuja ja piiririkkuja, sihipärast agentsust enam omanud kuju. Pole vähetähtis mainida, et karjatusperioodi välisel (talvisel) ajal on õige paljud karjused tegelnud küttimisega, teiste kõrval harrastas seda ka näiteks mu varemmainitud Ladva külast pärit karjusest informant (V. V.).

Lepingu sõlmimisel on karjuse asi olnud muu hulgas ka metshaldjale "tasu" lubamine karjatusperioodil tehtava töö eest. See on toimunud kõige ehtsama maagilise tingimise abil, milles pole ilmsesti puudunud vajadusel ka kavaldamine või pettus. Nagu eespool mainitud, on karjus lepingu tegemisel võinud kanda kindaid - mis viitab toimingu suurele rituaalsusastmele ning selle kaitsemaagilise turvamise vajalikkusele. Ühe teate kohaselt on karjus võinud esimesel aastal metshaldjale tasu- 
des läbi ajada ka vaid mõne munaga (nt Moroz 2001: 238-239). Hiljem on aga tasu pigem suurenenud, tavapärane on, et mets on igal aastal nõudnud ühe lehma karjast, mis on märgistunud kas karjuse tahtel või metshaldja valikul ning läinud karjast kaduma üsna karjatusperioodi alguses. Tasuteema leiab puudutamist ka järgmises tekstis:

Konz pästäškathe živatan mecha, käutihe eduu päivašt́ muražmätod tomha mécha. Todas puzuižuu da pandas uličähä, levitadas, miše kogomba živatad ḱäutas mécas. A potom aiditesho hiid kükstas arghiižuu päivau. Ümbriži živatoid om spusk paimńuu, kiŕǵitadut hänuu om bumagalo. Bumagaupäi hän lugeb ümbri živatoiš kuumé kerdat, a potom ńecon spuskan panob žerdiižen allo zavoroihe, kuspäi živat proiduškab mecha, vaudalo. Eraśiš spuskiš om, eźmäińe živat kudamb proidub, sen živatan mecauk otab. Necon živatan hän kuti edelozo paukaź paimetos, ńeco mecauk, a paimńele kebnemb paimeta linńeb.

[Kui loomad metsa lasti, käidi päev varem metsast sipelgapesa toomas. Tuuakse korvis ja puistatakse külatänavale, et loomad paremini koos metsas käiksid. Aga pärast argipäeval aetakse nad aedikusse. Loomade ümbardamiseks on karjusel spusk, kirjutatud tal paberile. Ta loeb paberilt kolm korda ümber loomade käies, aga pärast paneb selle spuski värava juurde laua alla, kust kaudu kari läheb metsa, omapäi. Mõne spuski puhul on, et see loom, kes esimesena läbi läheb, selle metsisand võtab. Selle looma ta nagu endale kauples karjatamiseks, see metsisand, aga karjusel on kergem karjatada.]

(Zaitseva \& Mullonen 1969: 149-150)

Karjus on, nagu eelpool mainitud, võinud tasuks karja hoidmise eest lubada metsale ka karja või mõne looma piimasaaki. Viimasel juhul on see võinud perenaistes tekitada kahtlusi, et mängu läheb just nende looma piim, millega seoses on püütud võita karjuse poolehoidu. Kui karjast on karjatusperioodil mõni loom surnud, siis on seegi kuulunud (vastavalt kokkuleppeloogikale) metsale - sel juhul on tavaline, et loom on tulnud maha matta terviklikult ja vigastamata - see tähendab, et temalt ei ole tohtinud näiteks nahka maha võtta, et seda majapidamises tarvitada saaks (Zelenin 1991: 88).

Eelnevast ilmneb rituaalijärgse loomakarja ühtesulatumine metsa, looduse ja maaga. Metatasandil on siin tegemist samastumise-samas- 
tamisega, ühtesulamine ei ole vaid ajutine silmamoondus. Karjus ei ole tohtinud mingilgi moel viga teha oma loomadele, aga ka mitte elusale loodusele ja maale. See on olnud (vähemalt "metsiku" lepingu puhul) universaalne imperatiiv, mis on tinginud ja taganud karjusele iseloomuliku rolliidentiteedi. Loomakarja terviklikkuse ning karjuse ja tema maagiliste riistade puutumatus on kohustusena kehtinud kõigile inimestele. Joonistub välja iseloomulik suhtetüpoloogia inimühiskonna ja metsa ja metsikuse vahel, mille keskel karjus (kuigi suhteliselt staatilisena) on mediaatori rollis, vahendades kahepoolselt erisuunalisi huvisid. Seesama vahepealsus on jälgitav ka karjusele kehtivate konkreetsete kohustuste puhul, samuti inimeste kohustustes tema suhtes.

\section{Karjuse käitumine ja talle kehtivad tabud ning kogukonna kohustused tema ees}

Karjuse positsiooni vahepealsus on väljendunud ka tema käitumises, talle kehtivates lepingulistes nõudmistes ja keeldudes, lõpuks ka väljanägemises ja iseloomulikus moraalsuses. Nagu juba öeldud, mahub karjuse tüüp traditsioonilise ühiskonna rollide galeriis kõige iseloomulikumalt “oma võõra” kujju (vrd Lotman \& Uspenski 1982), täpsemalt on selle tinginud nii ühiskondlikud ootused ja stereotüübid, rahvausu seisukohalt aga maagilise lepingu üksikasjad, millele karjusel on tulnud alluda. Asjata ei ole karjust võrreldud askeedi, pühamehe või ka eunuhhiga, st isikuga, kellele laienevad nii väljastpoolt seatud kui ka enda võetud ebaharilikud kohustused. Aunuse kubermangus on teda võidud nimetada otsesõnu mungaks (Fišman 1986: 195).

Lotman ja Uspenski on seoses "tõrjutu" kujuga vene kultuurikontekstis maininud tema sagedast pärinemist mujalt - antud indiviid on olnud kas välismaalane või vähemasti pärit väljastpoolt kogukonda. Seesama paistab silma ka karjuse päritolu käsitledes kogu läänemeresoome-põhjavene kultuuriruumis - hinnas on olnud just lähemast või kaugemast naabrusest pärit karjused, kusjuures paikkonniti on lausa välja kujunenud kindlad lähtealad (-rahvad), kust pärit karjuseid on peetud iseäranis väekaiks ja kuulsaiks. Nii on eri piirkondade vepslastel karjustena hinnas olnud vagaanid ja tšerepaanid (st Vaga jõe ja Tšerepovetsi kandi venelased, vrd Vinokurova 1988: 24-25), vadjalaste seas on hinnatud olnud Soikkola poolsaare isuritest karjused (Talve 1981: 54-55; Adler 1968: 135), Tveri karjalaste juures Arhangelski kubermangust pärit karjused (Virtaranta 1967: 103) jne. On ilmne, 
et selliste mujalt pärit karjuste puudumisel on võinud "kõlvata" mõni oma kogukonna marginaal. Salvestustes võib ka kohalikku päritolu karjusest jutustamisel tabada suhtumist "aga meil oli siin üks...", mis viitab otseselt mingile välistamisele, karjuse mittepidamisele tavaliseks inimeseks.

Kuivõrd iga lepingu puhul on tegemist olnud individuaalse üksikasjaliku kokkuleppega, ei saa luua mingit universaalset nimekirja rahvausus karjustele kehtinud nõudmistest. Võib olla kindel, et vahet on siin teinud (lisaks üksikjuhupõhisusele) ka see, kas tegemist on olnud "jumaliku" või "hirmsa" lepinguga. Eriti viimasel juhul on rõhutatud suurt askeetlikkust - karjus on olnud otsekui pühitsetud millessegi pingutustnõudvasse ja sealsamas salajasse. Karjuse tabudest kõneldes peame arvestama, et informatsioon pärineb ennekõike kogukonna tavaliikmete repertuaarist ning on seetõttu vähem või rohkem kumuleeritud ja üldistav.

Kehtinud keeldudest (vt Vinokurova 1988: 21-22; Moroz 2001: 240-241; Durasov 1988: 102-103; 1989: 274-275; Guljajeva 1986: 178; Štšepanskaja 1986; Mišurinskaja 2000b jpt) saame välja tuua jooni, mis kinnitavad eelpool väljatoodud printsiipe maagias: karja ja sellega seotud terviklikkuse olulisust; maa ja looduse, aga ka karja kui loodusele hoiuleantu hoidmise kohustust; inimestelt eeldatavat respekti karjuse-karja suhtes; karjusele endale kehtinud nõudeid, et mitte hälbida või libastuda maagilistest kokkulepetest, mis puudutavad ka seksuaalsust ja religioossust. Kuivõrd karjus on iseloomustatav inimkultuuri ja metsa või metsikuse vahemehena, kelle asi on olnud hoida tasakaalu, võib paljut tema käitumises iseloomustada just sellega - sfääridevaheline tasakaal on toiminud läbi karjuse enda psühhofüsioloogilise konditsiooni, mis ei ole tohtinud ei vaimselt ega füüsiliselt kahjustatud saada. Seda on taganud nii karjuse puutumatus muude poolt (mis on omakorda suurendanud tema tõrjutust ja anomaalsust), aga ka karjuse enda enesedistsipliin.

Just enesespüsimine ja mitte enesest väljaminek on olnud põhilisi imperatiive. Karjus ei ole tohtinud kellegi või millegi peale vihastuda. Suhetes karjusega on pererahvas pidanud hoidma mõistlikku distantsi ning hoiduma (halvemal juhul kasvõi väliselt) tema suhtes ebasümpaatia väljendamisest. Seda on toetanud ka mitmed tavakäitumuslikud nõuded. Kogu karjatusperioodi on karjus ööbinud kordamööda eri peredes. Talle on tagatud magamisase ja söök (sh ka metsa kaasa võtmiseks), mis üldjuhul ei ole tohtinud olla kehvem kui teistel. Lisaks varem kogukonnaga tehtud kokkuleppele palga osas, 
on iga pere pidanud karjust sel päeval, mil ta nende juures öömajal on, ka riietama - karjus on sel päeval karjas käinud talle perest antud riietega, mille ta ôhtul on vahetanud oma riiete vastu, liikudes järgmisel päeval uude peresse (vrd Guljajeva 1986: 174 jpt). Pere riietusega metsas käimises võib näha huvitavat sidet küla ja metsa vahel, mis on seotud karjuse füüsisega.

Samas on füüsilist kontakti karjusega kirjeldatud tabulisena. Karjus pole andnud kellelegi kätt (Štšepanskaja 1986: 168; Durasov 1988: 102), samuti pole ta tohtinud kelleltki midagi otseselt vastu võtta. Karjusele antud asjad on võidud asetada maha, kust karjus need siis võtnud on (Moroz 2001: 243). Karjuse distantseeritus ilmneb ka selles, et ta on võinud peredes söömisel kasutada eraldi, üksnes talle mõeldud toidunõusid ja süüa eraldi, samuti on ta käinud saunas pesemas teistest eraldi. Karjusel on olnud keelatud ka teiste jälgedesse astumine (Fišman 1986: 195). Füüsilised tabud viitavad otsekui karjuse erilisele laetusele, mis on võinud olla ohtlik kas muudele või siis (ühtlasi) maagilisele lepingule. Tuletame meelde, et karjuse asi on olnud kaitsta kõrvaliste (st kõigi teiste) eest ümbarduzt selle ainelisel kujul - kui maagilise lepingu kandjat. Ilmsesti on maagiline lepingulisus vähem või rohkem laienenud ka karjuse enda füüsisele, mistõttu on mõistetav tema füüsiline pühadus (või püha roojasus) kontaktides muude inimestega.

Pole teada, et karjus oleks saanud toimida mingi positiivse energia kandja või edastajana - karjuselt pole teadaolevalt saadud õnnistusi ega ole temaga seotut teadaolevalt kasutatud kasutoovas maagias. Sellega seoses on huvipakkuv, et mõne teate kohaselt pole karjus tohtinud käia kirikus (Fišman 1986: 195), ilmselt küllap "hirmsa" lepingu korral, st puutuda kokku (kõrgreligioosse?) kristluse kui "inimlikuga". Sealsamas on teiste teadete järgi pidanud karjus end eemale hoidma surnust või surmaga seotust - ta ei ole tohtinud olla lähedal, kui külas on olnud surnu (Moroz 2001: 240). Kalmistumulla kasutamine ümbarduze tegemisel on tulnud küll kõne alla (vrd Guljajeva 1986: 178), kuid see on kuulunud karjatamise perioodi eelsesse dünaamilisse faasi, mil eri vägede kasutamine on olnud asjakohane ja ilmselt lepingu efektiivsust suurendav. Hiljem, nagu karjusele kehtivatest tabudest ja vastavast kombestikust välja lugeda võime, on muud väed (peale metsa) olnud ("hirmsa" lepingu puhul) pigem välistatud.

Karjuse tasakaalust väljaviimisest hoidumisena võiksime käsitleda ka vandesõnade kasutamise ja riidlemise keeldu. Igasuguseid konflikte on karjus pidanud vältima ning ta pole tohtinud tegeleda 
muude, oma töö väliste probleemidega. Siia alla võiks lugeda ka karjuse kohustuse hoida ennast eemale lõbustustest ja seksuaalsuhetest. On rõhutatud, et karjus ei ole tohtinud osaleda ringmängudel - külanoorte lõbustustel, samuti magada naisega - samas pole karjusel olnud kohustust olla vallaline, kuna väljaspool karjatusperioodi on tal lubatud elada tavapärast elu. Selle taga pole ilmselt olnud üksnes tasakaaluhoidmise kohustus, vaid ka laiem sümboltaust, millest tuleb juttu eraldi. Riidlemise-pahandamisega samavõrd oluline, kui mitte veelgi tähtsam, on olnud karjusele verega seotud tabulisus. Karjus ei ole tohtinud valada kellegi verd (vrd siin ka keeldu loomi lüüa) ega teha iseendale viga nii, et veri välja tuleks. Karjuse ja kariloomade (kui lepingusse otseselt inkorporeeritud osapoolte) puhul on ilmne, et vere väljapääsuga saanuks taas rikutud mingi oluline tervik, mille kohta leping on sõlmitud. Teise inimese vere valamisega on karjus võinud aga rikkuda iseenda lepingulist puhtust, st muutunud lepingupartneri silmis ebakohaseks, määrituks.

Ilmsesti just "metsiku" lepingu puhul pole karjus tohtinud oma terviklikkust rikkuda ka juukseid-habet ajades, mille tulemusel on ta kujunenud ka väljanägemiselt igati "metsikuks". Karjus on olnud külas äratuntav seega mitte ainult oma tegevusala, vaid ka väljanägemise, haabituse tõttu. Vigastamiskeeluga seoses pole karjus kasutanud ka (metallist) tööriistu. Täpsemalt: ta polegi tohtinud teha töid, millega ta oleks võinud endale või teistele viga teha. Siin tuleb mõista aga juba mitte enam niivõrd teisi inimesi, kuivõrd just elusat (st metsikut) loodust ja selle esindajaid. Karjus pole tohtinud murda-lõikuda metsas puuoksi, aga nähtavasti pole ta samamoodi tohtinud niita heina. Keelatud on olnud metsas marjade söömine (mõne teate järgi "hirmsa" lepingu puhul musta karva marjade söömine). Iga tööga valitses ka oht teha tahtmatult viga loomariigi esindajatele (kasvõi putukatele) mis oli aga karjuse puhul välistatud. Karjus pole tohtinud arvatavasti tappa isegi sääski, misosas võiks teda vabalt võrrelda džainistlikule mungale kehtivate keeldudega igasuguse elu rikkumatul säilitamisel. Karjusele kehtinud tabud tulevad esile ka alljärgnevas näitetekstis, üldisemalt on need kokku võetud ja temaatilistesse klastritesse jagatud sellele järgnevas tabelis. ${ }^{7}$

Hän nece paimen, näge, $i$ voi ..., meca mäneb, ńägeb - marjad omma, marjoid $i$ voi kerata. Mid tatam oti peńemban necen sisaranke meca, mi mäńim(m)e i kerazime mustikeižen $i$ murikeižen. Tatam $i$ voin kerata. Tatam i tože en ollen puhud 
čapta ni mittužd. Ni midä-i ... Daže astud, ka muide astu. Kunutanke, kunud, kaika paimen kunutan karaulib ičellas nece rintol. Kunut nece hän om klavne kut ne obereg. I konz ottasoi necen [---] zavetan [---] obhodas otab hän ka, hän i mene..., ni

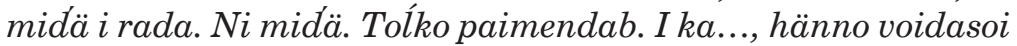
živatan travja, ili końdi tulob, ili häńdikas otab, ili muide lehm kunasse hajedab, $i$, näge, ende ka, nece, erasoi lehmoil maid haini, nece paimen toivuti mec-išandoile, miž-što algat kostku-i, voide konskai maidon otta, näge, no vot, muga oli. A muide ka $i$ ŕohtit ni midä rata. Kosketad mid̈̈, radad ka, ičellais hubudan teged, $i$ emägäd vet sindei patom radaso-i.

- Miced zapretad völ oliba paimenel?

$K a$, joda vinad $i$ san, a jo muga, humaloita hän ole $i$ san, torata

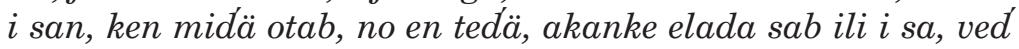
sab nece... a muide hän om muide ka kaik siäd kesan..., kut ne..., kut, tedan, evnuhhad elatasso muga, miž-što ni mid̈̈..., mine ni midä en rada, mine olen svjätõ ristit, tože olda..., kut nä..., kut sanuda..., angelad ka..., i nece..., i što mińä ni midä hubut en rada. Ni midä. Paremb i tehta hubad, ni midä en rada. Hän i hougoi, hän i pilí, hän i ni midä $i$ rada. Äkkid hän radab ka mičen ni živataisen ili mičen ni selžo säsken možet rikob ili

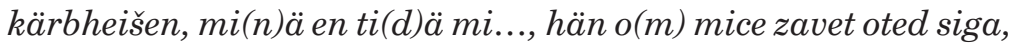
micen hän... paginan.

[Karjus, näed, ei või... metsa läheb, vaatab - marjad on, marju korjata ei või. Isa võttis meid väiksema õega metsa, me läksime ja korjasime mustikaid ja murakaid. Isa ei tohtinud korjata. Isa ei tohtinud samuti puid lõigata üldse. Mitte midagi... Kui astud, siis niisama astu. Piitsa, piitsa kõik karjus valvab, hoiab enda ligi. Piits see on talle kõige tähtsam, otsekui talisman. Ja kui ta võtab selle... obhodi võtab ta, ta läheb..., ja mingit tööd ei tee. Mitte midagi. Ainult karjatab. Ja... ta kari võib saada kahjustatud, või karu tuleb, või hunt võtab, või lehm niisama kuhugi kaob, ja, näed, enne ka, mõnel lehmal piim kadus, selle karjus lubas metsaisandale, et midagi ei juhtuks, lasi piima ära võtta, vot nii oli, näed. Aga muidu ka ei tohtinud mitte midagi (tööd) teha. Puutud midagi, teed tööd, teed endale halba, ja perenaised sind pärast enam ei palka.

- Millised keelud karjusel veel olid? 
Jah, viina juua ei saanud, niimoodi, purjus olla ei tohtinud, riielda ei tohtinud, kes mida võtab; no ma ei tea, kas naisega elada saab või ei saa, võib-olla saab..., aga muidu on ta, muidu kõik asjad suvel..., kui see..., nagu, ma tean, eunuhhid elavad niimoodi, et mitte midagi..., ma mitte midagi ei tee, ma olen püha inimene, samuti on..., kui see..., nagu öeldakse..., inglid ja..., ja see..., ja et mina mitte midagi paha ei tee. Mitte midagi. Et parem mitte halba teha, ma ei tee midagi. Ta ei lõhkunud puid, ei saaginud, ta ei tee midagi. Äkki ta töötab ja mõnele loomale teeb midagi või sääse äkki tapab või kärbse, ma ei tea..., mis lubaduse (zavet) ta võtnud on, millised... sõnad.]

(V. L., Vidl, Leningradi oblast, 2010)

\begin{tabular}{|c|c|c|c|c|}
\hline $\begin{array}{l}\text { Seoses } \\
\text { loodusega }\end{array}$ & $\begin{array}{l}\text { Seoses keha- } \\
\text { lise terviklik- } \\
\text { kuse ja vaimse } \\
\text { tasakaaluga }\end{array}$ & $\begin{array}{l}\text { Seoses } \\
\text { seksuaalsu- } \\
\text { sega }\end{array}$ & \begin{tabular}{|l|} 
Seoses \\
maagilise \\
lepingu/ \\
loitsuga \\
\end{tabular} & $\begin{array}{l}\text { Seoses muu- } \\
\text { de sfääride / } \\
\text { rituaalidega }\end{array}$ \\
\hline $\begin{array}{l}\text {-loomadele, } \\
\text { lindudele, } \\
\text { putukatele } \\
\text { viga teha } \\
\text { (täielik } \\
\text { töökeeld) } \\
\text { • puid- } \\
\text { põõsaid } \\
\text { vigastada } \\
\text { •metsaande } \\
\text { korjata-süüa }\end{array}$ & $\begin{array}{l}\bullet \text { juukseid-habet } \\
\text { ajada } \\
\bullet \text { ennast või } \\
\text { teisi veristada } \\
\bullet \text { vanduda- } \\
\text { riielda }\end{array}$ & $\begin{array}{l}\bullet \text { naisega } \\
\text { sugulises } \\
\text { vahekorras } \\
\text { olla } \\
\bullet \text { näha (pere) } \\
\text { naise kuu- } \\
\text { verd, tema } \\
\text { paljaid jalgu, } \\
\text { katmata pead } \\
\bullet \text { meelelahu- } \\
\text { tustes osaleda }\end{array}$ & $\begin{array}{l}\text { •läbi aia- } \\
\text { augu ronida } \\
\text { •ümbarduzt } \\
\text { hoidvaid } \\
\text { esemeid } \\
\text { (kepp, rihm } \\
\text { vm) käest } \\
\text { anda }\end{array}$ & $\begin{array}{l}\text { •käia } \\
\text { matustel } \\
\bullet \text { käia } \\
\text { kirikus }\end{array}$ \\
\hline
\end{tabular}

Tabel 1. Karjusele kehtida võinud keelud.

Puutumatus inimlikku on võinud väljenduda keelus võtta-katkuda põllult naereid või viljapäid (mis ilmselgelt ei ole seotud metsiku loodusega). Rõhutatud on, et karjusel on olnud keelatud läbi aiaaukude ronimine. Siin võib näha sidet loitsudes esineva karja ümbritseva maagilise tara sümboolikaga. Aiaaugust läbi ronimisega oleks karjus otsekui viidanud karja kaitsva tara läbitavusele, rikkudes sellega jälle lepingu pidamist. Oleme siin jõudnud rituaali põhimõiste juurde - ümbarduz, obhod jne ning seda tähistanud maagiline tegevus väljalaskmisel põhinebki kaitsval ümberpiiramisel, mis ühtlasi teeb 
kariloomad ka nähtamatuks-tabamatuks, põhineb aga sealsamas kokkuleppel, mille hapra balansi hoidmine on karjuse põhitöö.

Ümbarduz tähistab ühelt poolt mitut justnagu erinevat asja, mis rahvausu metatasandil iseloomustavad kontseptuaalselt aga üht ja sedasama. Ümbarduze all saab mõelda piiramisrituaali ennast; lepingut kogukonna ja metsa vahel, vastavat loitsuteksti suulisel või kirjalikul kujul; loitsu/lepingu materiaalset kandjat või kehastajat (vahapalli loomakarvadega, lukku, signaalinstrumenti jne), mida on vaja olnud hoida salajas või kõrvalistele kättesaamatuna; ehk ka helilist signaali, mis on olnud vaid karjuse vallata loomade kutsumisel. Lepingu osana on ka karjus ise olnud otsekui osa ümbarduzest - tema isik on olnud kõige sellega lausa mehhaaniliselt seotud, lahutamatu.

\section{Kultuuriliselt konstrueeritud sugupool ning seksuaalsus karjusemaagias}

Mitmed aspektid karjatamisega seotud kombestikus kutsuvad uurima soo - ennekõike kultuuriliselt konstrueeritud soo osatähtsust kogu nähtusekompleksis. Kuivõrd karjatusperioodil, maagilise lepingu kehtimise staatilises faasis on karjusele kehtinud mitmeid tema argiselt inimlikku olemist (sealhulgas ka seksuaalsust) piiravaid või muutvaid ettekirjutusi, ei saa see olla pelk juhuslik "moraalinorm". ${ }^{8}$ Teiselt poolt pole laiem sümboolne seksuaalsus võõras vist üheski uskumussüsteemis, kus näiteks jumalike olendite selleteemaline läbikäimine mõjutab otseselt inimlikku maailmakorda jne. Kolmandaks tuleb silmas pidada, et igasugune traditsioonilises kultuuris esinev viljakuse ja edenemisega seotud uskumuslikkus kaldub implitsiitselt olema seotud seksuaalsuse, ka orgiastilisusega.

Viimasega seotut võib märgata ka karjatamisega seotud kombestikus, seda just kogukonna/naiste poolt esitatuna. Mõnede teadete (Zelenin 1991: 90) kohaselt on perenaine võinud karja väljalaskmisel pühkida loomade selgi särgiga, milles ta on mehega maganud. Selles saab näha otsest viidet seksuaalsusele, mida kontaktsuse teel saab edasi kanda, eesmärgiks loomade hea sigivus (vrd ka Tarkka 1998: 121). Just naiste riideesemed ja nende kandmisega seotud tähendused on siin kesksel kohal, mille kaudu joonistub välja perenaise (feminiinse) seotus karjaga, seda vähemalt kodu/inimliku sfääris (mis on ka mõistetav ja ootuspärane). Ilmsesti tekib siin omamoodi konkurentsimoment kogukondliku ja metsaga seotu vahel, kus karjusel on tulnud täita 
vahemehe rolli, ennekõike aga hoolt selle eest, et inimlik ei saaks kuidagimoodi domineerida lepingupartneri - metsa - üle. Seda võib välja lugeda mõnest näitest: kui loomi välja lastes on naiste seelikuääred mingil põhjusel (tuul) üles tõusnud, on usutud, et loomad saavad suvi otsa, sabad seljas, ringi jooksma. Viimast saab aga karjuse seisukohalt tõlgendada ebasoodsana. Karja väljalaskmisel on naiste-tüdrukute hüppamine tähistanud-soodustanud karja reipust ja jõudlust suvel (Zelenin 1991: 89). Karjala ainesele toetudes on väidetud, et naiselik seksuaalsus ja viljakus oli karjaga kõige otsesemas seoses - nii sümboolselt kui ka vastava kontaktsuse ja rituaalsuse vahendusel. Laura Stark on eristanud positiivset ja negatiivset naiseliku seksuaalsuse mõju, käsitledes harakoimise (nom harakoiminen) nimetuse all tuntud rituaali või olukorda, kus kariloomad lähevad välja laudauksel seisva naise harkis jalge vahelt või kui naine juhtub üle astuma mingist asjast või esemest, millele ta avaldab seeläbi spetsiifilist mõju (Stark-Arola 1998a: 47-50; 1998b: 166-168, 224 jj). Kodusfääris (st naise maailmas) on sellel olnud positiivne, kaitsev mõju, mitte aga väljaspool. Selge vahe on siin olnud lehmade ja hobuste vahel, viimased on olnud selgelt meeste teema (vrd Vinokurova 2006: 290, 320-322). Perenaise suhe oma kariloomadega (ennekõike lehmadega) on olnud sensuaalne (Tarkka 1998: 121).

Seega on ilmne, et naistel on olnud karjale teatav maagiline mõju, mida karjus on pidanud kontrolli all või üldse ära hoidma. Nagu juba varem kirjeldatud, on karjusel tulnud kontrollida perenaise riietust (paljapäi-paljajalu olemise keeld) karja juures, vajadusel perenaist kasvõi piitsaga korrale kutsudes. Karjuse suhe karjaga on olnud pigem vaigistav ja rahustav. Ta on pidanud olema seksuaalsuse taltsutaja. Võib olla kindel, et eelmainitud surnuaiamulla kasutamine ümbarduzel on teeninud just sama eesmärki. Naisele on omistatav ühtpidi seotus kodusfääriga ning ta ei ületanud üldjuhul piiri metsikusse sedavõrd nagu seda tegid mehed. Samas on naised olnud seotud looduse ja stiihiaga oma viljakuse kaudu (vrd Tarkka 1998: 116-117). Karjuse roll on seega olnud kummaliselt vahepealne - ta on pidanud puhverdama inimlikku ja stiihilist, kus iganes see ka esile ei tule. Tundub, et just selles rollis on inimvälise stiihia (metsa) ja inimühiskonnas esile tuleva stiihia (naiselikkus) tajumine, ohjamine ja omavaheline maandamine olnud kesksel kohal.

Perenaise ebakohase riietuse nägemise või mittesallimise kõrval on karjusele ilmsesti sama ohtlikud olnud otsesed viited feminiinsele viljakusele või viljastatavusele. Sellega on seotud karjusele kehtiv 
keeld osaleda külanoorte ringmängudel. Karjus ei ole tohtinud näha menstruatsiooniverd perenaise riietel (Štšepanskaja 1986: 169), üldse pidi perenaine pärast mehega läbikäimist end pesema ja riideid vahetama enne, kui sai minna karja välja laskma (Stepanova 2000: 31). Viimast võib siduda ka üldisema verekeeluga karjuse tabude seas, aga kindlasti on siin mängus ka seksuaalne aspekt. Üldine tabu on karjuse jaoks olnud seksuaalsuhe naistega, ka oma naisega. Siit koorub välja omamoodi "kolmanda soo" kultuuriline konstrueeritus kindla bioloogilise soo esindaja seksuaalse orientatsiooni ajutine või täielik muutmine peamiselt ühiskondlikest huvidest lähtuvalt. Sarnaseid näiteid võib ajutistena tuua näiteks šamaanirituaalidest, kus vastaspoolega efektiivse suhtlemise nimel kogukonna hüvanguks oma geenust muudetakse. Pidevat (eluaegset) "kolmandat sugu" võib leida mitmelt poolt maailmast (India, Tai, Albaania ${ }^{9}$ jne), erinevates ühiskondlikes olukordades.

On ilmne, et karjuse puhul võib juttu teha soolise orientatsiooni muutmise esimesest, perioodilis-ajutisest juhust. Oma ülesande täitmise nimel ning suhetes teispoolsusega (metsaga) ei saa karjus esineda aktiivse, maskuliinse osapoolena, vaid peab võtma seksuaalselt passiivse, pigem "sootu" või "kolmandasoolise" positsiooni. Täpseim on siinkohal nähtavasti karjuse võrdlemine eunuhhi või mungaga. Laiemalt kinnitab seda ka karjuse töökeeld. Just tööde kaudu on traditsioonilises ühiskonnas markeeritud erinevaid soorolle (meestetööd vs naistetööd). Karjus pole tohtinud ega saanud demonstreerida oma mehelikku jõudu, mis töödes esile tuleb. Samuti pole ta saanud karjatamisperioodil kasutada terariistu (samuti mehelikule aktiivsusele viitavad atribuudid). Karjus on olnud passiivne piirihoidja-piiripidaja, mitte aktiivne sissetungija. Sellega koos pole ta tohtinud viga teha maale-loodusele, mida saab samastada feminiinse poole seksuaalse rikkumise, sissetungiga.

Karjuse roll karjatusperioodil on olnud selles osas vastupidine teise metsa ja maagiaga seotud rolli - küti - omaga. Ehkki ka jahimees on pidanud teadvustama ja ilmutama respekti metsa ja metshaldja kui saakloomade isanda suhtes ning võinud kinni pidada mõnedest seksuaalsetest tabudest (vahekord naisega jahi eel, naiste ja naiseliku väe eemalehoidmine jahiriistadest), on tema suhe metsa olnud siiski teistsugune. Erinevalt karjusest pole jahimees liikunud piirialal, vaid olnud metsatungija - sissetungija, kelle asi on olnud ajutine tasakaalu rikkumine (saakloomade tabamine, tapmine), kusjuures hiljem on see tasakaal vastavate riituste abil taas jalule seatud. Nii küti tegevus kui 
vastav sõnavara kubiseb seksuaalsetest konnotatsioonidest. Sarnaselt armumaagiale on kütt kavaldaja, meelitaja, "jahtija”, jahilkäigu sümbolkeel on samastatav kosimise või abiellumisega (ka Tarkka 1994: 253-254; 1998: 99-109; Ilomäki 1986: 59, 126-130). Jahipidamist iseloomustab just perioodiline piiririkkumine. See on reeglitepõhine sissetung võõrasse sfääri, mehelikkust esile toov tegevus.

Kolmandasoolisusel on ühiskonnas alati piireületav funktsioon. See on pigem (ennast)ohverdav rollilisus, millele pealtnäha ei ole omane inimlik kirglikkus. Jahipidamise emotsionaalsus on iseloomustatav saagiiha ja hilisema rituaalse kahetsusega, ühtlasi ka soovitusliku peenetundelisusega eesmärgi saavutamisel. Seesama iseloomustab ka mehelikku seksuaalsust või seksuaalsust üleüldse. Kui tavapärases seksuaalsuses on isiklikud ihad ja instinktid üpriski esilolevad, siis kultuurilise kolmandasoolisuse puhul on need allasurutud - nii selle praktilised kui ka maagilised ülesanded lähtuvad kollektiivsetest huvidest. Sellele, et karjus ei ole tabude kehtimise perioodil "tavaline mees" vaid keegi muu (kolmas), viitab ka Nina Hagen-Torni poolt 20. sajandi esimesel poolel talletatud teade, et isuri abielunaiste suletud ringi orgiastilistele jüripäeva pidustustele, kus rikuti tavapäraseid käitumisnorme, võis tulla ka karjus (vt Pantšenko 1998: 103). Karjus on pidanud niisiis ohverdama oma tavapärase meheliku seksuaalsuse, et ühiskonna huvides tulla toime üldisema elutähtsa tasakaalu hoidmisega. Seetõttu on karjuseks võinud paiguti olla ka poisikesed või vanamehed, ehk siis inimesed, kes ei ole fertiilses eas (vrd Tarkka 1998: 122).

\section{Karjus ja kristlik maailm}

Eelnevas on juba juttu olnud karjuse tihedast seotusest metsa ja inimvälisega. Igal konkreetsel aegruumilisel juhul peame inimese ja metsa suhet eraldi silmas pidama. Vepslaste puhul võime jälgida pigem pikka neutraalset partnerlussuhet metsaga, eriti võrreldes läänepoolsemate läänemeresoome rahvastega, aga ka venelastega. Üheks selle oluliseks põhjuseks võime pidada alekultuuri kestmist 20. sajandi keskpaigani, milles pikaajaline kokkupuude ortodoksse kristliku kõrgreligioossusega pole kaasa toonud otsest animistliku maailma demoniseerumist, vaid pigem osapoolte omavahelist kombineerumist. Vene rahvakultuuris näib "metsiku" ja "jumaliku" obhodi vahel valitsevat selge hinnanguline veelahe, ent on võimalik, et veps- 
lastel pole seda nii selgelt eksisteerinud. Üks põhjusi on võinud olla ka keeleline distants, mis säilis vene keele keskpärase valdamise tõttu samuti 20. sajandi keskpaigani ning takistas vastavate venekeelsete kirjalike loitsude tundmist ja levimist.

Oluline osa kristlike ideede tungimisel rahvakultuuri ja nende suhtes rahvalikult vastuvõtlikumaks muutumisel on olnud nähtusel, mida võib nimetada rahvapäraseks hardusliikumiseks. Näib, et selle levimisel on suur tähtsus olnud just vahetul kokkupuutel kirikliku ja kloostrieluga, suurtel pühadel ja ristikäikudel käimisega, personaalses plaanis on võinud seda soodustada elulised vapustused ja läbielamised. Viimastel sajanditel on selle levimisele kaasa aidanud ka mitmed lahkusulised sektantlikud liikumised Põhja-Venemaal. Just selliste arengute tõttu on rahvapärane maailmapilt võinud muutuda hüppeliselt dualistlikumaks, mille tulemusena kogu ümbritsev on kujunenud otsekui hea ja kurja, jumaliku ja metsiku kompromissituks võitlusväljaks (nt livvikarjalase Nastja Rantsi jutupärimuses (Järvinen 2004: 147 jj)), kus poolevalimine on olnud möödapääsmatu. Tundub jällegi, et võrreldes muude etniliste rühmadega on vepslastel olnud selle teemaga mõnevõrra tagasihoidlikumad kokkupuuted. Vaieldamatult on kohalikud kabelipühad, aga ka pikemad sesoonsed kloostriretked ning noorukite perioodilised sinna teenimajäämised olnud tähtis osa vepslaste elust. Samas näib, et suures osas on sellest ikkagi eemale jäädud, st kõrgreligioossete otseallikate ja igapäevaelu vahele on jäänud piisav keelelis-kultuuriline ja elulaadiline filter, mis on jätnud vepslased pikemaks ajaks elama neile omasesse maailma.

Kirjalik kultuur on põhjavene areaalis olnud sajandeid seotud jumalasõnaga. Raamatud on olnud kiriku ja kloostrite atribuutika osa ning nende kaudu levinud kirjalikkus on mõtestunud autoriteetsena ka kirjaoskamatutele inimestele. Karjusemaagias paistab see silma kirjalike otpuskite hinnatuses, mis on suurendanud karjuste autoriteeti või olnud mitmel pool lausa nende palkamise eelduseks. Selliste karjuste valduses olnud kirjapandud "raamatukeste" sisu on olnud ennekõike kristlik-apokrüüfiline, mis omakorda viitab pigem "jumaliku" obhodi ja pühakutega partnerlussuhte suunas, kus metsal on võinud olla pigem negatiivne kui neutraalne konnotatsioon. Ka vepsa karjuste puhul leidub teateid sellest, et karjustel on olnud selliseid "dokumente". Ühe suulise teate selle kohta kuulsin 2011. aasta suvel Vilhalas (Leningradi oblast) sealselt kauaaegselt kooliõpetajalt ja pärimusega seotud asjade healt teadjalt A. Š.-lt. 2015. aasta välitöödel 


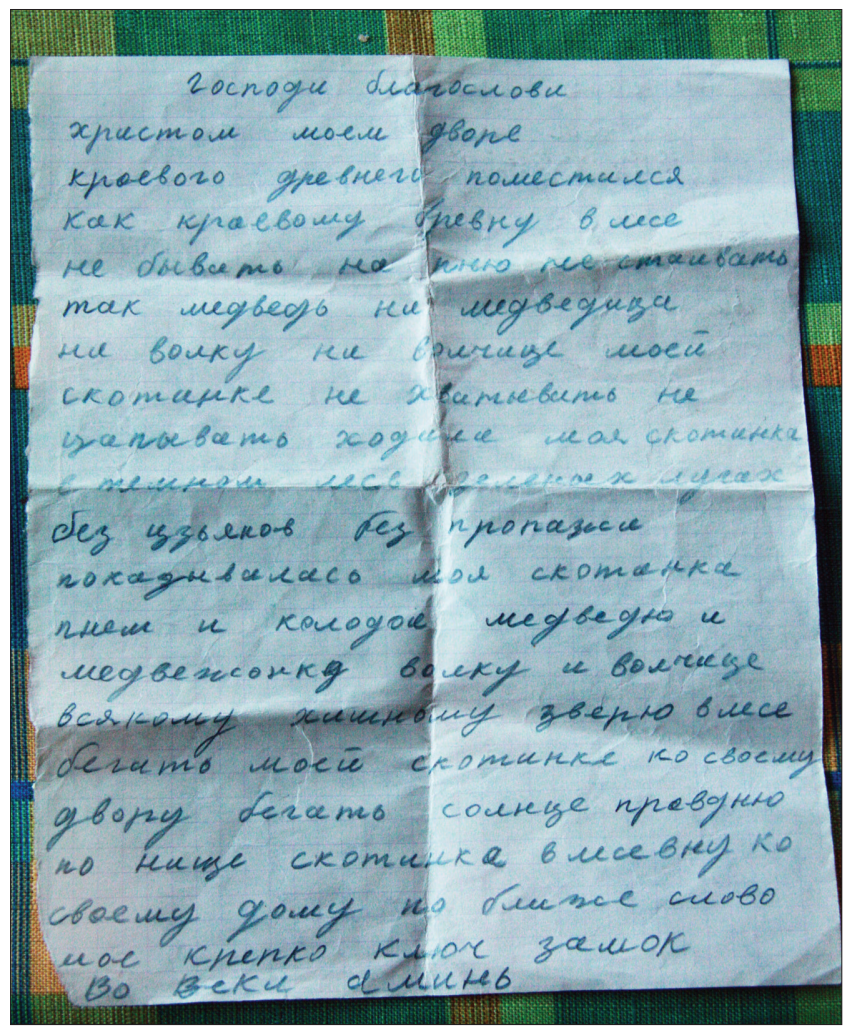

Foto 5. Karjuse kirjalik otpusk. Maagiline tekst Päzarest. Madis Arukase foto 2015.

õnnestus mul Päžaŕes (Vologda oblast) kopeerida kaks sellist venekeelset vihikulehele kirjutatud teksti, mida nende omanikud - vepslastest karjused - olid veel hiljaaegu kasutanud. Loomulikult on kirjalikkus ja raamatulikkus (seda ka kirjaoskamatutele ning mõistmatus keeles) omanud autoriteedi ka vepslaste silmis - ehkki anomaalse ja pigem mitteomana. Teadaolevad säilinud karjuste "raamatud" põhjavene areaalis on kõik ootuspäraselt venekeelsed ning nende varasem päritolu seostatav ilmselt vanausulistega. 
Omaette huvitav küsimus on seotud vepsakeelsete loitsude üleskirjutamisega ning sellega, kas vepsakeelsed ümbarduzega seotud tekstid on kirjapandutena võinud kuuluda ka karjuste maagilisse "varustusse". Küsimus on asjakohane, sest vanimad teadaolevad läänemeresoomekeelsed loitsude üleskirjutused (ilmsesti küll mitte rahvapäraselt) on teada ju 17. sajandi esimesest poolest (nn Aunuse kogumik - Toporkov 2010). Kuigi neis võib kohata ka maagilise seina ehitamise kujundit, ei ole ühelgi juhul tegemist otseselt karjamaagias kasutusel olnud tekstidega. Me ei saa eitada võimalust, et vepsakeelseid vastavaid tekste on piisava kirjaoskuse korral üles kirjutatud ning et nad on sel moel ka karjustel kasutuses olnud, kuid vastavate andmete puudumisel jääb meil oletada, et pigem on sellistena levikus olnud ennekõike venekeelsed tekstid, mille kasutajad on olnud valdavalt ehk vene karjused, mis omakorda võiks kõnelda ka kristlike suundumuste (“jumalik" obhod) suuremast levikust just vene ning vähem läänemeresoome (või vähemalt vepsa) karjusemaagias (kuivõrd sellesarnaste loitsude adresseeritus on üldjuhul suunatud kristlikele pühakutele).

Tuleb muidugi silmas pidada, et otsese mehhaanilise seose nägemine pühakuid appikutsuva loitsuteksti ja kristliku maailmavaate vahel võib olla samuti forsseeritud, kuivõrd rahvapärane toimimisviis on ennekõike brikolaažne, mitte ideoloogiline. Kristlik hardusdiskursus on siin kindlasti oma korrektiive teinud, kas see on saanud tungida aga sügavale karjusekombestikku, on kaheldav. Karjuse valdkond on kõigele vaatamata olnud piisavalt autonoomne ja tema roll kohustuslikult äärepealne. Vaatamata kuitahes kristlikule maailmapildilisele mõjule on siin alles jäänud oma iseärased inimkultuurivälised metsaga seotud kontaktid ja kogemused, millega karjusel on tulnud silmitsi seista kasvõi tahtmatult (vrd nt Pentikäinen 1987: 84).

Karjus on äratuntavalt eraldiseisev ka rahvapärase legendirepertuaari tegelasena, mis kinnitab tema iseäralikku positsiooni just põhjavene-läänemeresoome kultuuriruumis. Iseloomulikult on siin kõne all jumaliku naistegelasega seotud süžeed, ja tegelane, kelle suhtes karjus käitub oponendina. Selline legendipärimus on eriti levinud Ingerimaal (ja üldse mitte niiväga vepsa traditsioonis), aga ka vene traditsioonis ning käsitleb Jumalaema, eriti aga Püha Paraskeva ilmutusi kas inimlikul kujul või ikoonina. Üheks sellise ilmutusloo tuntuimaks toimumiskohaks Loode-Venemaal on Ilješi küla, kus vastav legend on seotud ka loodusobjektidega - kasepuuga, mille otsas naispühak karjusele ilmnes või kuhu ta karjuse eest põgenes, samuti 
kivi, millele jäid püha naistegelase jäljed, kui ta oli puult alla tulnud, või oja, mis jäi temast põgenemisel maha.

Vastavas pühakulegendis näeb metsas karjatav karjus iseäralikku naisolendit, keda ta arusaamatul põhjusel vaenama asub - üritades puu otsa pagenud naist kas piitsaga lüüa (mille peale võib piits puusse kinni jääda) või kividega visata (kivi jääb puusse kinni). Alles seejärel teatab ta juhtunust teistele külaelanikele, misjärel ilmutuse positiivne pühalikkus laiemalt mõistetavaks saab. Ergo-Hart Västrik, kes on uurinud vastavaid vadja tekstivariante, on nimetanud karjuse sellist teguviisi ebaloogiliseks ning katsunud lugu interpreteerida kui hübriidi algsest etioloogilisest (dualistlikust) tekkeloost, mis hiljem on segunenud kristliku ilmutuslooga. Karjuse käitumine on seeläbi seletatav rudimendina varasema hiiu tegusemisest, kes loobib kive või on muul viisil vastaliselt meelestatud (Västrik 2007: 146-151). Et pühakuloos on keskseks negatiivseks tegelaseks saanud (laste kõrval) just karjus, jääb siin juhuslikuks või on seletatav asjaoluga, et selline roll saabki loos sobida vaid marginaalile, samuti on karjusele avaldatud ilmutuslikkus omane legendirepertuaarile ka rahvusvaheliselt.

Ehkki võib tõdeda, et karjus võib neis legendides esineda sarnases positsioonis metshaldja või kuradiga (vrd näiteteksti Pantšenko 1998: 154), ei ole vist siiski vajadust otsida tema tagant mingit varasemat arhailisemat tegelaskuju. Karjuse "vastalisus" on legendis igati ootuspärane ja seletatav ta tavapärase (staatilise) rollikäitumisega. Veelgi enam, pole vist juhuslik, et mitmed pühakuloo variandid sisaldavad ka inimlikule ebakohasusele ja/või seksuaalsusele viitavaid elemente, mille suhtes karjus ei võinud ükskõikseks jääda. Nii on Paraskeva/ Jumalaema vastavates folklooritekstides kas lahtiste juustega või paljajalu, puu otsas istudes on ta jalad risti (vrd jalg üle põlve istumise tabulisus traditsioonilises rahvausus ja kombestikus). Kuivõrd karjuse asi on olla kontaktis teispoolsega (saada ilmutusi) ning lugeda märke, siis põhjendab see ka tema käitumise automaatsust - ta sõitleb ja lööb ebakohaselt ilmuvat naist, mis viitab kriitilisele olukorrale, milles karjuse seisukohalt on ohtu sattunud tasakaal inimliku ja mitteinimliku vahel, nagu me seda eelpool juba kirjeldasime.

Tähelepanuväärne on pühakulugudes ehk ka see, et naisolend toimib siin selgelt loodust muutva-transformeeriva tegelaskujuna temast jääb kivisse jälg, samuti rikub ta maapinda, tekitades sinna oja või allika. Maa/looduse rikkumine on samuti üks karjusele negatiivselt mõtestuvaid asju, talle isiklikult tabu. Pühakuloos esitatud situatsioon on karjuse vaatepunktist seega "eluline" ning karjuse käitumises pole 
midagi ebaloogilist. Legendi geneesi silmas pidades on pigem huvitav, miks on pühakulugu liidetud just karjuse kuju ja tegutsemisega. Vastus sellele on samavõrd ootuspärane, ning siin joonistub välja juba antud temaatikat kesksena läbiv vastuolu või üleminek eelkristliku ja kristliku, metsiku ja jumaliku ning muude sarnaste muutumislooliste seikade vahel, mis karjusekombestikus meile esile tulevad.

Lisaks teadjale on nõidkarjus metsavööndi kultuuriruumis olnud ilmsesti kõige sobivam roll eelkristliku kultuuripildi kehastuseks, sattudes nii lõpuks pühakuloos ühte ritta metshaldja ja kuradiga. Ilmselt on see põhjuseks, miks karjus võib legendis lüüa mitte üksnes ebatavalist naist, vaid ka ikooni. Samas ei ole üha enam kristianiseerunud rahvakultuur oma traditsioonilisel kujul lõpuni läbi saanud nimetatud vastandlike (või vastaliste) rollideta - teadja, karjuseta. Me võime näha, kuidas on toimunud karjuse ja karjatamiskombestiku ja -uskumuste (ennekõike esmakordsel väljalaskmisel) järk-järguline modifitseerumine kristliku suunas, kuid karjus sellise rollina nagu ta on meie ees põhjavene ja läänemeresoome rahvaste idapoolsemate (vepsa, karjala, Ingerimaa) rühmade traditsioonis, on hakanud kaduma alles koos traditsioonilise kogukonnapõhise eluviisi minetumisega, koos moderniseerumise ja hilisema ajaloo ühiskondlike vapustustega.

\section{Kokkuvõtvaid küsimusi}

Kui vaatleme karjusekultuuri läänemeresoome-põhjavene kultuuriruumis, avaneb meie ees rida küsimusi. Siinkirjutaja silmis huvitavaimad probleemid on seotud kahe valdkonnaga - metsaga lepingus oleva nõidkarjuse kui rolli genees ning läänemeresoome-slaavi kultuuri-suhete ajalooga seotud küsimused selle taustal.

Esimese probleemi keskmes näib omakorda olevat karjuse kultuuriliselt konstrueeritud soo küsimus, selle võimalik taust ja juured, mille paralleelid tunduvad olevat üpris mitmekesised. Karjusele kehtinud tabud - ennekõike teatud vaikimiskeeld ja elusloodusele kahjutegemise keeld - esinevad mitmetes muudeski kultuurides. Hea, kuigi mitte geneetilises suguluses oleva näitena respektist putukariigi ning muu elusa vastu üleüldiselt on näiteks India džainism. Selle usundi munkadel-nunnadel on muuhulgas keelatud millegi elusa tahtlik või tahmatu vigastamine. Askeesiharjutuste hulka kuulub seal ka enese sääskedel süüalaskmine. Keeld endale kogunevaid putukaid tappa- 
peletada esineb ka karjusetabude seas. Loomulikult on džainismis rangelt jälgitud ka seda, et juhuslikult ei tehtaks kellelegi viga - pühendunumad kannavad endaga pidevalt kaasas luuakest, pühkides liikudes teed enda ees, et mitte tallata väikemaid elusorganisme.

Võrdlus džainismiga on siinkohal loomulikult näitlik, mitte geneetilisele seosele viitav. Vaikimiskeeldu võib aga kohata märksa lähemal - õigeusklikus kloostrikultuuris, kus see kehtib iseäranis rangele askeesile pühendunud usuränduritele (strannikud). Õigeuskliku kõrgkultuuri seoseid karjusetraditsiooniga võime märgata nii piiramisrituaalis tervikuna - piirkonniti-juhuti on karja õnnistamist võinud toimetada ka õigeusklik papp ning sel juhul on see toimunud loomulikult õigeusklike palvete saatel. Kirjakultuuriga paardunult levinud "jumalik" obhod on võimalik näide õigeusu ja rahvakultuuri sümbioosist, kui mitte lausa kõrgreligiooni elementide või kogu rituaalistruktuuri kandumisest õigeusust rahvakultuuri. Sel juhul oleks karjuse anomaalsus või "pühamehelikkus" seletatav otsese kopeerimisega õigeusust, mis rahvakultuuris on võtnud iselaadse travestia kuju.

Tähelepanuvääriv on ka seksuaalsuse ja kultuuriliselt konstrueeritud soo küsimus karjuse puhul. Antud juhul on ilmselgelt tegemist ajutise "soovahetuse" või seksuaalse orientatsiooni muutmisega, mis kehtib üksnes hooajalisel karjatusperioodil, karjuserolli "staatilises" faasis. Ka siin võiks näha paralleele õigeuskliku mungastaatusega, mis kujutab endast vastava tõotuse andmist ning sellele järgnevat (kas ajutist või igavest) pöördumist maisest elust, koos kõige selle juurde kuuluvaga. Neile liistudele asetatuna mõjuks karjuse askeetlikkus taas veidra laenu või kopeeringuna õigeusklikust kõrgkultuurist, kõrvuti rahvapärase, kristlike segmentidega loitsutraditsiooni ning muu apokrüüfilisega.

Ilmsesti ei ole karjuse "kolmandasoolisus" käsiteldav eluaegsena, iselaadse eunuhluse või kultuurilise soovahetusega, liikumaks ühest soost igaveseks teise. Vastupidi: karjuse seksuaalsetes tabudes naispoole suhtes võib märgata korrelatsiooni maa ja loodus - feminiinne. Karjusele on koos sugulise lähedusega keelatud ka maa/looduse rikkumine. Midagi sarnast võib kohata ka seoses läänemeresoome maahinguse pühitsusega, mil on keelatud olnud maaga seotud tööd või üldse maapinna rikkumine-vigastamine mistahes moel, paiguti aga ka seksuaalne lähedus naisega (st naise terviklikkuse rikkumine - vrd nt teade Põlva kihelkonnast: ristineljapäivan es tohi mehega magada, sis pand lina kõik maha nigu hakki, Hiiemäe 1984: 182). See kompleks on tõenäoliselt seostatav põlluharimiskultuuridele iseloomu- 
liku maa feminiseerimisega, millele vastandub taeva isasus. See, mis meestele kehtib vaid mõnel üksikul päeval, on karjusele kehtiv kogu hooajal - tagamaks piiri püsimist ja rikkumatust eri poolte vahel. Sel moel viibiks karjus maagilise lepingu garandina otsekui kogu aeg pühas - kogu karjatamisperiood on tema jaoks otsekui püha aeg ja situatsioon. Kas selline pühalikkus on kitsalt (ja kopeerivalt) õigeusklikku päritolu, pole samas kindel. Saati on vepslaste (aga substraatselt ka põhjavenelaste) puhul tegemist ikkagi metsarahvaga, kelle kultuuris domineeris alepõllundus (mitte põlispõllundus) ning suhted metsa kui teispoolsusega ei põhinenud mitte üksnes vastandumisel, vaid ka partnerlikel suhetel.

Siinkohal tõstatubki küsimus seoses karjuse, ennekõike "metsikut" ümbarduzt läbiviiva nõidkarjuse kui rolli mittekristlikust geneesist. "Metsikus" lepingulisuses võime kõige selgemalt tajuda partnersuhet metsaga - mets ja metsahaldjas kui kokkuleppelise tasu ja tingimuste eest karja (oma loomade eest) hoidev usaldusisik. J. Lotman on juhtinud tähelepanu igasugu lepingulisuse paganlikule anomaalsusele ja tõrjutusele õigeusklikus vene kultuuris (1999: 241 jj), selge on aga see, et läänemeresoomelik karjusemaagia ei kujuta endast paganlikku päritolu rooma õigusega Euroopast laenatud nähtust, vaid pigem midagi algupäraselt kultuuriomast. See viitab aga karjuse kui rolli kultuuriliselt teisele võimalikule kaalukale juurele, mis tuleneb kristluse-eelsest rahvakultuurist.

Soomuutused rituaalsetes olukordades on iseloomulikud šamanismile, kus šamaanil tuleb oma teispoolsete kaitsevaimudega adekvaatseks läbimiseks (vrd pühas ühtimiseks) ajutiselt (kultuuriliselt) sugu muuta. Selline transvestiitsus on šamanismis pigem tavaline ning sooliste rollide mitmekesisus (aga ka leplikkus nende suhtes) näib šamanistlikes (eelkristlikes) kultuurides üldjuhul olevat suurem ja levinum. Šamanistlikke jooni läänemeresoome teadja-kultuuris on esmajoones käsitlenud Anna-Leena Siikala (2002). Fakt on kindlasti see, et šamanistlik kultuuritüüp koos sellele omase transi- ja teispoolsuselembusega on millalgi ümber vahetatud teadja-keskse (ale)kultuuri vastu, milles teispoolse ja püha sfäärid asuvad füüsiliselt hoomatavamas läheduses ning suhtlemine nendega ei eelda sedavõrd muutunud teadvuse seisundit ning selle saavutamise kultuurilisi tehnikaid. Šamaanilaulude asemel retsitatiivseid loitse kasutav teadja on ise olnud maagilise teadmise kandja ning pole selle hankimiseks pidanud pidevalt transsilangemist praktiseerima (vrd Siikala 2002: 345-346). 
Sellegipoolest mõjuvad mõned karjusemaagias esiletulevad jooned otsekui kaudsed viited šamanismile. Jutt käib siin ennekõike juba kõneldud soolise orientatsiooni ajutisest muutumisest, aga miks mitte ka metsa kui abistava animistliku sfääri toest tervikuna, samuti karjuse instrumentide (pasun, piits, kuuselauast trumm jne) maagilisest mõjust tegelikkusele. Karjus "oma võõrana" (vrd Lotman \& Uspenski 1982) pole kaasaegses perspektiivis kultuurikeskne, vaid piiritagune, sealt tulev ja oma tööajal ka "seal asuv". Ta on kontrollivas-sanktsioneerivas suhtes argise tegelikkuse ja kogukonna igapäevaeluga. Samas ei kahtle keegi läänemeresoome või põhjavene kultuuris tema autoriteedis ja vajalikkuses, tema kui erilise suhtes tuntakse respekti ning püütakse olla talle meelepärane. Põlluharijakultuurile iseloomuliku asemel (resp. sellega kõrvuti) oleks siin meie ees läbikäimine teispoolsega, mis ei orienteeru kuigivõrd kristlikul religioossel maastikul, vaid kasutab endiselt varasemaid skeeme ja võtteid. Olgu siintoodud tabelis näha mõned olulisemad erinevused kultuuritüübi, karjuse kui rolli ja vastava maagia asjus:

\begin{tabular}{|l|l|}
\hline Alekultuur & Põllumajanduskultuur \\
\hline $\begin{array}{l}\text { Looduse ja inimkultuuri vaheline } \\
\text { partnersuhe }\end{array}$ & $\begin{array}{l}\text { Looduse ja inimkultuuri vaheline } \\
\text { võistlus }\end{array}$ \\
\hline Suulisus & Osaline kirjalikkus \\
\hline "Metsik" piiramisrituaal & "Jumalik" piiramisrituaal \\
\hline Nõidkarjus & Karjus kui marginaal (tobu) \\
\hline Karjus kui piiri kontrollija & Karjus kui piiri rikkuja \\
\hline $\begin{array}{l}\text { Karjuse perioodiline } \\
\text { "kolmandasoolisus" }\end{array}$ & Karjus kui läbikukkunud mees \\
\hline
\end{tabular}

Tabel 2. Traditsiooniökoloogiliste kultuuritü̈̈pide erinevused karjusemaagia põhjal.

Kuivõrd iseloomustab käsiteldav karjusekultuur etnostevahelisi, st läänemeresoome-slaavi ajaloolisi suhteid? Arvestades asjaolu, et karjuse eriline staatus on levinud just soome-ugri aluspõhjaga metsastes piirkondades ja sellisena üldse mitte vene lõunapoolsetes piirkondades või ka näiteks ukraina kultuuris, võime üsna julgelt oletada selle läänemeresoomelist algupära. Selle vaate kohaselt on slaavi põlluharimiskultuur hiljem kombineerunud metsakarjatuskultuuriga ning lisanud sinna oma kõrgreligioosseid ja kirjakultuurseid elemente. See seletus tundub üpriski loogiline. Huvitava nüansina 
tuleb aga märkida, et ka idaslaavi kultuuriruumis eksisteerib oma metsakultuur, millel ei ole arvatavasti sedavõrd seost läänemeresoome (soome-ugri) aluspõhjaga. Jutt käib siin metsastest Polesje piirkondadest, kus on täheldatavad sarnased karjusekultuuri jooned seoses metsa ning karjuse erilise rolliga.

Päris selgelt on karjatamine metsastel Põhja-Euroopa idaaladel juurutanud end mõne viimase aastatuhande jooksul ning on sellisena vanem põlispõllundusest, samuti kristluse tulekust. Seega tuleb möönda vaadeldud karjusmaagia soome-ugrilikku algupära ning mitmeid algupäraseid elemente selles, mis hiljem on osati kombineerunud või asendunud slaavilik-õigeusklikuga. Selline sünkretistlik elujõulisus kuni karjatamise kui eluala täieliku taandumiseni tänapäeval viitab selle pikaajalisele olulisusele ja kestvusele kultuuris. Karjus sotsiaalse rollina on siin ootuspäraselt säilitanud ja kombineerinud erinevaid elemente ilmsesti väga mitmekesisest rollide galeriist nii geneetilise järgnevuse kui külgnemiste kaudu.

\section{Märkus}

Uurimust toetasid Alfred Kordelini Sihtasutus ning Eesti Vabariigi Haridus- ja Teadusministeerium (projekt IUT2-43).

\section{Kommentaarid}

1 Informantide nimed on ära toodud vaid initsiaalidega; tekstinäited on pärit autori välitöösalvestistest (v.a need juhud, kui on juures arhiiviviide vm allikaviide).

${ }^{2}$ Perioodilise metsas elutsemise kohta vepslastele lähedaste lüüdilaste traditsioonis vt Virtaranta 1963: 340-342.

3 A. Moroz on ühes oma lühiartiklis rõhutanud, et karjused on oma juttudes sageli "metsiku" ja "jumaliku" lepingu ning selle elemendid segi ajanud. Ta eraldab printsipiaalselt tavapärase piiramise "metsiku" ümbarduze tegemise osana, lõpuks aga asub "metsiku" ümbarduze kui rituaali toimumise suhtes üldse kahtlevale seisukohale (vt Moroz 2003).

4 Samas eksisteerib ka suhteliselt vanu vepsakeelseid loitsude üleskirjutusi (varaseimad 17. sajandist, vrd Toporkov 2010: 107-110, 132-133, 137-139; ka Vinokurova 1988: 20-21). 
5 Samas võib siin kindlasti kõnelda ka uskumusolendite sulandumisest. Nii on äänisvepsa horahine võinud endas kanda nii Püha Jüri, õue- kui ka metshaldja jooni (vrd Oinas 1980: 349).

${ }^{6}$ On tähelepanuväärne, et mu pikaaegne informant V. L. Vidlast on viimastel aastatel jüripäeviti asunud omal initsiatiivil rituaalselt piirama kogu külaosa, kus ta elab.

7 Vt ka vastavat arutelu Taisto Raudalaineni artiklis samas kogumikus, lk 85-136.

8 Tatjana Štšepanskaja on sel puhul kasutanud mõistet "reproduktiivne tabu" (2001: $85 \mathrm{jj})$, kus meeste maagias on väge alles hoitud "antikreatiivse" käitumisega.

9 Albaanias ikka veel levinud naissoost mehe funktsiooni täitva virgjeresheinstitutsiooni kohta vt nt Novik 2012.

\section{Arhiiviallikad}

RKM Mgn II - Eesti Rahvaluule Arhiivi monofooniliste lindistuste kogu.

\section{Kirjandus}

Adler, Elna 1968. Vadjalaste endisajast, I. Idavadja murdetekste. Tallinn: Eesti NSV Teaduste Akadeemia.

Anttonen, Veikko 1992. "Püha" mõiste rahvausundi uurimises. Akadeemia 12, lk 2514-2535.

Arukask, Madis 2009. Kesk-Vepsa teadjaga vesteldes: erinevad maailmapildid ja rollid. Annuk, Eve (koost, toim). Paar sammukest. Eesti Kirjandusmuuseumi aastaraamat XXV. Tartu: Eesti Kirjandusmuuseumi Teaduskirjastus, lk 122-145.

Bobrov \& Fintšenko 1986 = Бобров, А. Г. \& Финченко, А. Е. Рукописный отпуск в пастушеской обрядности Русского Севера (конец XVIII - начало XX вв). Бернштам, Т. А. \& Чистов, К. В. (vast toim). Русский Север: проблель этнокультурной истории, этнограббии и фбольклористики. Ленинград: Наука, lk 135-164. 
Durasov $1988=$ Дурасов, Г. П. Обряды, связанные $c$ домашним скотоводством на Каргополье, в конце XIX - начале XX в. Чистов, К. В. (vast toim). Культура Русского Севера. Ленинград: Наука, lk 99-107.

Durasov 1989 = Дурасов, Г. П. Обряды, связанные с обиходом скота в сельской общине Каргополья в XIX - начале XX в. Русские: селейный и общественный был. Москва: Наука, lk 265-282.

Fedosova $2010=$ Федосова, К. А. Слово и действие в пастушьих отпусках: устное бытование рукописного текста. Фольклор: текст и контекст. Москва, lk 131-142.

Fišman 1986 = Фишман, О.М.Связь пастушеской и свадебной обрядности у карел. Бернштам, Т. А. \& Чистов К. В. (vast toim). Русский Север: проблель этнокультурной истории, этнографбии и ббольклористики Ленинград: Наука, lk 190-205.

Gennep, Arnold van 1960. The Rites of Passage. Chicago: The University of Chicago Press.

Golubeva 1987 = Голубева, Л. А. Весь. Седов, В. В. (vast toim). Финно-угры и балты в эпоху средневековья. Москва: Наука, lk 52-64.

Guljajeva 1986 = Гуляева, Л. П. Пастушеская обрядность на реке Паше (традиция и современность). Бернштам, Т. А. \& Чистов К. В. (vast toim). Русский Север: проблемы этнокультурной истории, этнографбии и фбольклористики. Ленинград: Наука, lk 172-180.

Heikkinen, Kaija 1994. Havaintoja magian käytöstä vepsäläisissä kylissä. Heikkinen, Kaija \& Mullonen, Irma (toim). Vepsäläiset tutuiksi. Karjalan tutkimuslaitoksen julkaisuja. 108. Joensuu: Joensuun Yliopisto, lk 145-168.

Hiiemäe, Mall 1984. Eesti rahvakalender III. Tallinn: Eesti Raamat.

Holmberg, Uno 1923. Metsän peitossa. Kalevalaseuran vuosikirja 3. Porvoo: WSOY, lk 16-60.

Honko, Lauri 1994. Belief and Ritual: The Phenomenological Context. Honko, Lauri \& Timonen, Senni \& Branch, Michael (koost). The Great Bear. A Thematic Anthology of Oral Poetry in the Finno-Ugrian Languages. New York: Oxford University Press, Finnish Literary Society, lk 63-77.

Ilomäki, Henni 1986. Eläinten nimittäminen ja luontosuhde. Petojen roolit pohjois- ja rajakarjalaisissa kalevalamittaisissa runoissa. Folkloristiikan julkaisematon lisensiaatintutkielma.Helsinki: Helsingin yliopisto. 
Joalaid, Marje. Vepslastest ja vepsa keelest. fennougria.ee (http://www. fennougria.ee/index.php?id=19761 - 29.01.2016).

Joalaid, Marje 1998. Vepslased ja vepsa keel. Joalaid, Marje (toim). Kaheksa keelt, kaheksa rahvast. Tallinn: Tallinna Pedagoogikaülikooli Kirjastus, lk 50-70.

Järvinen, Irma-Riitta 2004. Karjalan pyhät kertomukset. Tutkimus livvinkielisen alueen legendaperinteestä ja kansanuskon muutoksista. Suomalaisen Kirjallisuuden Seuran Toimituksia 962. Helsinki: Suomalaisen Kirjallisuuden Seura.

Kettunen, Lauri 1925. Näytteitä etelävepsästä II. Helsinki: Suomalaisen Kirjallisuuden Seura.

Krinitšnaja 1986 = Криничная, Н. А. О сакральной функщии пастушьей трубы (по материалам северных пастушеских обрядов). Бернштам, Т. А. \& Чистов К. В. (vast toim). Русский Север: проблель этнокультурной истории, этнографби и фбольклористики. Ленинград: Наука, lk 181189.

Lonin $2000=$ Лонин, Р. П. Записки краеведа. Петрозаводск: Музейное агентство.

Lotman, Juri 1999. "Leping” ja "eneseloovutus" kui arhetüüpsed kultuurimudelid. Semiosfäärist. Tallinn: Vagabund, lk 237-259.

Lotman \& Uspenski 1982 = Лотман, Ю. М. \& Успенский, Б. А. "Изгой" и “изгойничество" как социально-психологическая позиция в русской культуре преимущественно допетровского периода. TRÜ toimetised, vihik 576 (Труды по знаковым систелам XV). Типология культуры. Взаимное воздействие культур. Tartu: Tartu Ülikool, lk 110-121.

Lönnqvist, Bo 1999. Sotsiaalsed ideaalid ja kultuurimustrid 20. sajandi Soomes. Järs, Anu \& Kannike, Anu \& Pärdi, Heiki (toim). Skandinaavia kultuurianalü̈̈s. Studia Ethnologica Tartuensia 3. Tartu: Tartu Ülikooli Etnoloogia õppetool, lk 115-127.

Mišurinskaja 2000a = Мишуринская, Л. И. Знахарь и знахарство в Тихвинском и Лодейнопольском районах Ленинградской области. $V$ региональная научная конферениия молодых ученых "Этнографбиеское изучение Северо-Запада России”. Краткое содержание докладов. Издательство Санкт-Петербургского университета, lk 67-69 (http://www.ethnology.ru/ doc/conferences/Tesis-2000.rtf - 29.01.2016). 
Mišurinskaja 2000b = Мишуринская, О. В. Пастушеская обрядность (Тихвинский и Лодейнопольский районы). $V$ региональная научная конфберениия молодых ученых "Этнографическое изучение СевероЗапада России”. Краткое содержание докладов. Издательство СанктПетербургского университета, lk 58-61 (http://www.ethnology.ru/doc/ conferences/Tesis-2000.rtf - 29.01.2016).

Moora, Tanel 2008. Vepsa asustuslugu. Ettekanne seminaril "Vepslased siitpoolt vaadates. Vanad teadmised ja uued küsimused”. Tartu, 17. okt 2008.

Moroz 2001 = Мороз, А. Б. Севернорусские пастушеские отпуска и магия первого выгона скота у славян. Восточнославянский этнолингвистический сборник. Москва: Индрик, lk 232-258.

Moroz 2003 = Мороз А. Б. "Лесной отпуск". Тайное знание севернорусского пастуха и его репрезентация в крестьянской общине. Локальные традииии в народной культуре Русского Севера (Материаль IV международной конферениии “Рябининские чтения-2003"). Петрозаводск, lk 206-208.

Morozova 2001 = Морозова, И. А. "Отпуск” пастуха из Каргопольского р-на Архангельской обл. / Подготовка к публикации. Мужской сборник. Выпуск 1. Мужчина в традиционной культуре. Москва: Лабиринт, lk 120-124.

Mullonen 1994 = Муллонен, И. И. Очерки вепсской топонимии. СанктПетербург: Наука.

Mullonen, Irma 2005. Vepsän etnisen alueen muodostuminen paikannimistön perusteella. Saressalo, Lassi (toim). Vepsä. Maa, kansa, kulttuuri. Tampere: Tamperen museot, Helsinki: Soumalaisen Kirjallisuuden Seura, lk 48-62.

Novik 2012 = Новик, А. А. Виргьереши - девственницы Северо-Албанских Альп как феномен социальной структуры традиционного общества. Фенолен социализации в этнической культуре. Материаль ХІ СанктПетербургских этнограббических чтений. Санкт-Петербург, lk 72-79.

Oinas, Felix J. 1980. Pyhä Yrjänä metsänhaltijana. Virittäja 4, lk 347-350.

Pantšenko 1998 = Панченко, А. А. Исследования в области народного православия. Деревенские святыни Северо-Запада России. СанктПетербург: Алетейя. 
Pentikäinen, Juha 1987. Oral Repertoire and World View. An Anthropological Study of Marina Takalo's Life History. Folklore Fellows' Communications 219. Helsinki: Academia Scientiarum Fennica.

Pimenov 1965 = Пименов, В. В. Вепсьь. Очерк этнической истории и генезиса культуры. Москва \& Ленинград: Наука.

Raudalainen, Taisto Kalevi 2001. Traditsioonisidus elulooline jutustamine: mäluainese etnopoeetiline tekstualiseerimine. Anepaio, Terje \& Kõresaar, Ene (toim). Kultuur ja mälu. Studia Ethnologica Tartuensia 4. Tartu: Tartu Ülikooli Kirjastus, lk 59-78.

Salve, Kristi 1995. Vepsa metshaldjapärimus tänapäeval. Hiiemäe, Mall \& Kõiva, Mare (toim). Rahvausund tänapäeval. Tartu: Eesti TA Eesti Keele Instituut, lk 356-378.

Schöpflin, George 1999. The Politics of National Identities. Branch, Michael (toim). National History and Identity: Approaches to the Writing of National History in the North-East Baltic Region Nineteenth and Twentieth Centuries. Studia Fennica, Ethnologica 6. Helsinki: Finnish Literature Society, lk 48-62.

Siikala, Anna-Leena 2002. Mythic Images and Shamanism: A Perspective on Kalevala Poetry. Folklore Fellows' Communications 280. Helsinki: Academia Scientarum Fennica.

Siikala, Anna-Leena 2012. Itämerensuomalaisten mytologia. Helsinki: Suomalaisen Kirjallisuuden Seura.

Stark, Laura 2002. Peasants, Pilgrims, and Sacred Promises. Ritual and the Supernatural in Orthodox Karelian Folk Religion. Studia Fennica, Folkloristica 11. Helsinki: Finnish Literature Society.

Stark-Arola, Laura 1998a. Gender, Magic and Social Order. Pairing, Boundaries, and the Female Body in Finnish-Karelian Folklore. Apo, Satu \& Nenola, Aili \& Stark-Arola, Laura (toim). Gender and Folklore. Perspectives on Finnish and Karelian Culture. Studia Fennica, Folkloristica 4. Helsinki: Finnish Literature Society, lk 31-62.

Stark-Arola, Laura 1998b. Magic, Body and Social Order: The Construction of Gender Through Woman's Private Rituals in Traditional Finland. Studia Fennica, Folkloristica 5. Helsinki: Finnish Literature Society. 
Stepanov 2006 = Степанов, А. В. Некоторые аспекты животноводческой магии на Русском Севере. Морфология праздника. Издательство СанктПетербургского университета, lk 254-266.

Stepanova 2000 = Степанова, А. С. Устная поэзия тунгудских карел. Петрозаводск: Периодика.

Štšepanskaja 1986 = Щепанская, Т. Б. "Знание” пастуха в связи с его статусом. Бернштам, Т. А. \& Чистов К. В. (vast toim). Русский Север: проблемы этнокультурной истории, этнографби и фбольклористики. Ленинград: Наука, lk 165-171.

Štšepanskaja 2001 = Щепанская, Т. Б. Сила (коммуникативные и репродуктивные аспекты мужской магии). Мужской сборник. Выпуск 1. Мужчина в традиционной культуре. Москва: Лабиринт, lk 71-94.

Zaitseva \& Mullonen 1969 = Зайцева, М. И. \& Муллонен, М. И. Образиы вепсской речи. Ленинград: Наука.

Zelenin 1991 = Зеленин, Д. К. Восточнославянская этнография. Москва: Наука.

Talve, Ilmar 1981. Vatjalaista kansankulttuuria. Suomalais-ugrilaisen seuran toimituksia 179. Helsinki: Suomalais-Ugrilainen Seura.

Tarkka, Lotte 1994. Other Worlds - Symbolism, Dialogue and Gender in Karelian Oral Poetry. Siikala, Anna-Leena \& Vakimo, Sinikka (toim). Songs Beyond the Kalevala. Transformations of Oral Poetry. Studia Fennica, Folkloristica 2. Helsinki: Finnish Literature Society, lk 250-298.

Tarkka, Lotte 1998. Sense of the Forest: Nature and Gender in Karelian Oral Poetry. Apo, Satu \& Nenola, Aili \& Stark-Arola, Laura (toim). Gender and Folklore: Perspectives on Finnish and Karelian Culture. Studia Fennica, Folkloristica 4. Helsinki: Finnish Literature Society, lk 92-142.

Toporkov 2010 = Топорков, А. Л. Русские заговоры из рукописных источников XVII - первой половины XIX в. Москва: Индрик (http:// verbalcharms.ru/books/Toporkov1.pdf - 29.01.2016).

Trifojev 2013 = Трифоев, В. П. Сказание о Нелже. Санкт-Петербург.

Vinokurova 1988 = Винокурова, И. Ю. Ритуал первого выгона скота на пастбище у вепсов. Обряды и верования народов Карелии. Петрозаводск: Карельский филиал АН CCCP, lk 4-26. 
Vinokurova 1994 = Винокурова, И. Ю. Календарные обычаи, обряды и праздники вепсов (конеи XIX-начало XX в.). Санкт-Петербург: Наука.

Vinokurova 2006 = Винокурова, И. Ю. Животные в традииионных верованиях вепсов. Петрозаводск: Издательство Петрозаводского государственного университета.

Virtaranta, Pertti 1963. Lyydiläisiä tekstejä = Lüdische Texte I. Suomalaisugrilaisen seuran toimituksia 129. Helsinki: Suomalais-Ugrilainen Seura.

Virtaranta, Pertti 1967. Lähisukukielten lukemisto. Suomalaisen Kirjallisuuden Seuran Toimituksia 280. Helsinki: Suomalaisen Kirjallisuuden Seura.

Västrik, Ergo-Hart 2007: Ílloša külakabeli legendid vadja rahvapärimuses. Kõiva, Mare (toim). Sator 6. Artikleid usundi- ja kombeloost. Tartu: EKM Teaduskirjastus, lk 134-160.

Whitehouse, Harvey 2008. Cognitive Evolution and Religion; Cognition and Religious Evolution. Issues in Ethnology and Anthropology, n. s. 3. No. 3, lk 35-47 (http://www.anthroserbia.org/content/pdf/articles/whitehouse cognitive_revolution_and_religion.pdf - 29.01.2016).

\section{Summary}

\section{Herding culture of Vepsians and northern Russians: Roles, taboos, and sexuality in the traditional society of the temperate zone forest belt}

Madis Arukask

Keywords: cultural gender, herder, magic, northern Russian, soothsayer, taboo, Vepsian

This article discusses the role of the herder and the related magic on the basis of folklore materials of the Finnic peoples (mainly Vepsians) and northern Russians as well as earlier research in the field. In traditional culture, the influence of which in places lasted until the end of the 20th century, the herder was a mediator between human beings and nature in the forest belt. As domestic animals constituted an essential part of the community's resources, different forces of the animistic world had to be taken into account when tending them. 
The herder as the key person was part of the magic contract and, during the herding period, was subject to different conventional taboos. He not only took care of the livestock but also controlled the morality of the human society and channelled the tensions between nature and human society. This provided the herder with a characteristic social role, with a singular behaviour, which highlighted features related to social ostracism and atypical gender behaviour. The genesis of the role is of interest due to its relationship with the institution of tedai (community healer and sorcerer, the-one-who-knows), yet it also involves influences from Christianity. 


\section{Uurimusi vepsa rahvausust}

Koostaja ja toimetaja Madis Arukask

http://www.folklore.ee/rl/pubte/ee/sator/sator16/

ISSN 1736-0323 (veebiväljaanne)

ISBN 978-9949-544-96-7 (veebiväljaanne)

ISSN 1404-2011 (trükis)

ISBN 978-9949-544-95-0 (trükis)

DOI: 10.7592/Sator.2016.16

Tartu 2016

Sarja toimetaja: Mare Kõiva

Koostaja ja toimetaja: Madis Arukask

Keeletoimetaja: Asta Niinemets

Kaas ja kujundus: Andres Kuperjanov

Kaanefoto: Madis Arukask

Küljendus: Diana Kahre

HTML: Diana Kahre

Trükis ilmunud: Uurimusi vepsa rahvausust.

Koostaja ja toimetaja Madis Arukask. SATOR 16. Tartu 2016

Raamatu ettevalmistamist ja väljaandmist on toetanud Eesti Teadusagentuur (grandid nr 7385 ja 9271) ning Eesti Vabariigi Haridus- ja Teadusministeerium (projekt IUT 2-43). Raamatu toimetamist ja vormindamist toetas Euroopa Liit Euroopa Regionaalarengu Fondi kaudu (Eesti-uuringute Tippkeskus), see on seotud Eesti Teadusagentuuri institutsionaalse uurimisprojektiga IUT 22-5. Trükitud Eesti Kultuurkapitali toetusel.

E-raamatu valmimist toetas: EKKM14-344 Eesti keele, kultuuri ja folkloori kasutusalade laiendamine ja tutvustamine elektroonilistel infokandjatel.

(C) 2016 EKM Teaduskirjastus

(C) 2016 Eesti Folkloori Instituut

() 2016 EKM FO rahvausundi ja meedia töörühm

(C) 2016 autorid 